\title{
HYDROLOGY, AQUATIC MACROPHYTES, AND WATER QUALITY OF BLACK EARTH CREEK AND ITS TRIBUTARIES, DANE COUNTY, WISCONSIN, 1985-86
}

By

Stephen J. Field and David J. Graczyk

Water-Resources Investigations Report 89-4089

Prepared by

U.S. Geological Survey

Prepared in cooperation with the

Wisconsin Department of Natural Resources



Madison, Wisconsin 


\section{UNITED STATES DEPARTMENT OF THE INTERIOR}

MANUEL LUJAN, JR., Secretary

GEOLOGICAL SURVEY

Dallas L. Peck, Director

For additional information

write to:

\section{District Chief}

U.S. Geological Survey

6417 Normandy Lane

Madison, Wisconsin
Copies of this report can be purchased from:

Open-File Services Section Western Distribution Branch U.S. Geological Survey Box 25425, Federal Center Denver, Colorado $\mathbf{8 0 2 2 5}$ Telephone: (303) 234-5888 


\section{CONTENTS}

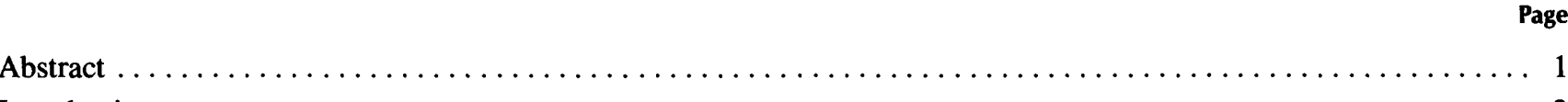

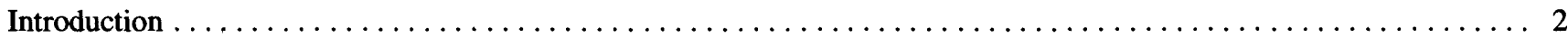

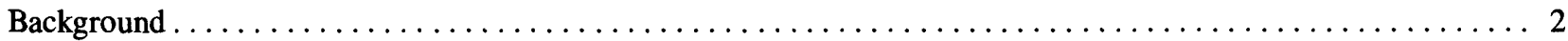

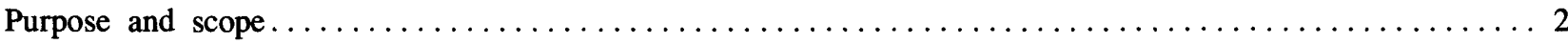

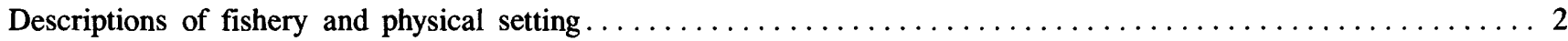

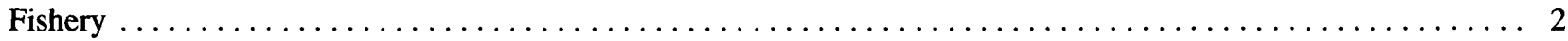

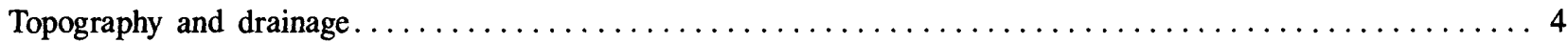

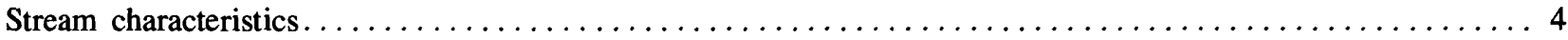

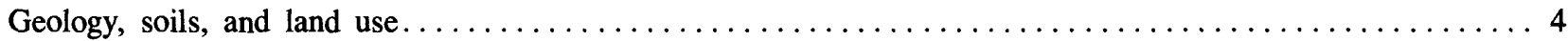

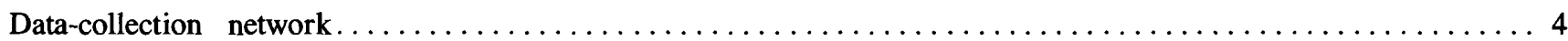

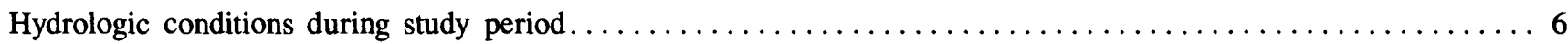

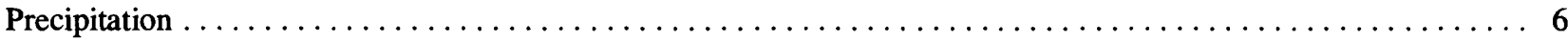

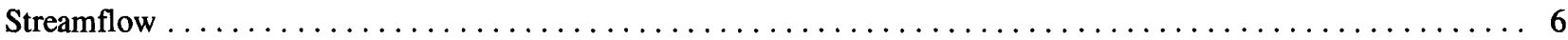

Comparison of streamflow during 1985 and 1986 water years $\ldots \ldots \ldots \ldots \ldots \ldots$



Aquatic macrophytes, by John D. Madsen, Michael S. Adams, and William Kleindl................



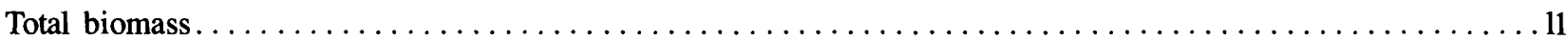

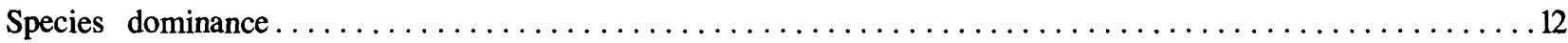

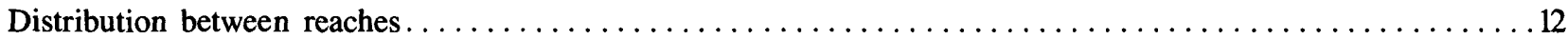





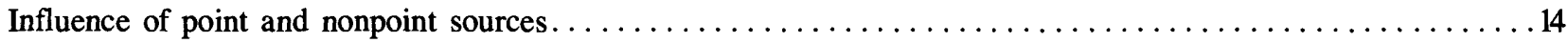

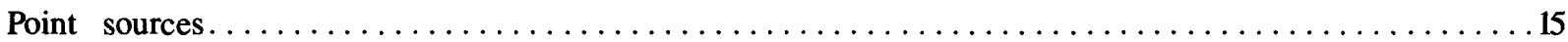

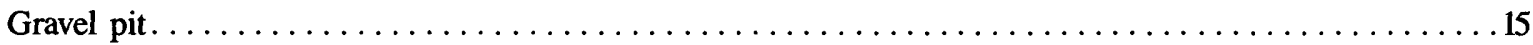





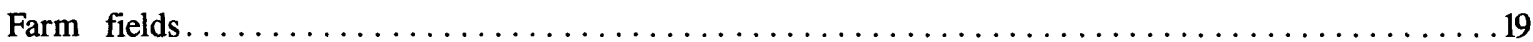

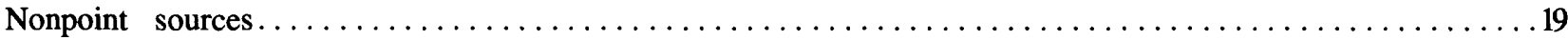









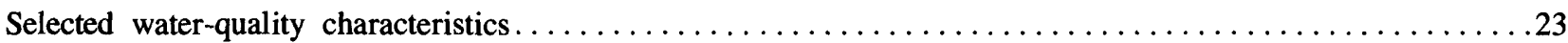

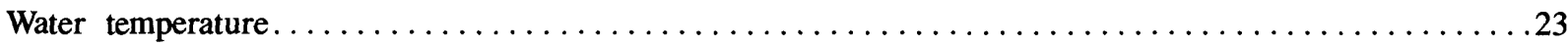

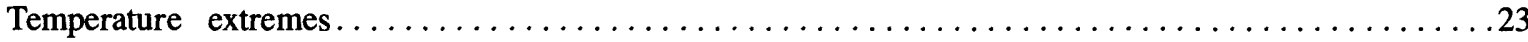

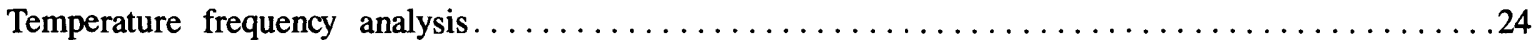





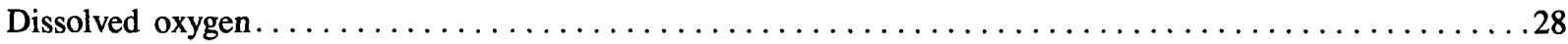





Effects of gravel-pit discharge on dissolved-oxygen concentration $\ldots \ldots \ldots \ldots \ldots \ldots \ldots \ldots \ldots \ldots \ldots$




Page

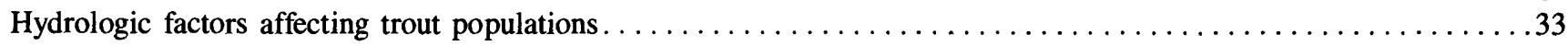

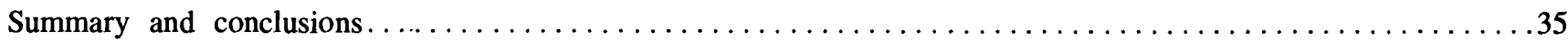

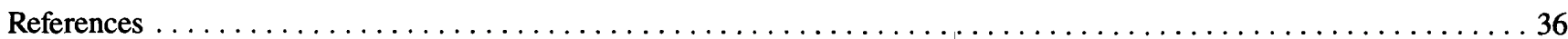

\section{ILLUSTRATIONS}

Figure 1. Map showing location of the Black Earth Creek basin in Wisconsin

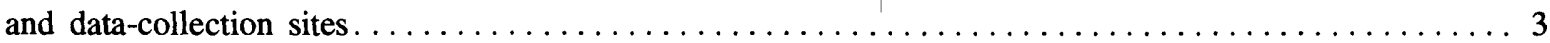

2-12. Graphs showing:

2. Trout populations in Black Earth Creek, 1954-86, from one-half mile downstream

from Garfoot Creek to one-half mile upstream from Cross Plains . . . . . . . . . . . . .

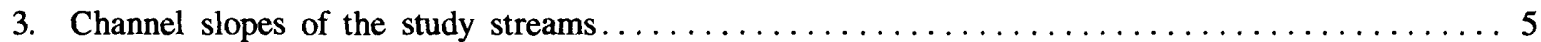

4. Annual mean streamflow in Black Earth Creek, $1955-86$ water years . . . . . . . . . . . . 7

5. Hydrograph separations for base flow and surface runoff for Black Earth Creek at Black Earth and Brewery Creek at Cross Plains, 1985 and 1986 water years. . . . . . . . 8

6. Annual mean water level in observation well $\mathrm{Iw}-110 \ldots \ldots \ldots \ldots \ldots \ldots$

7. Black Earth Creek low-flow discharge, 1985 and 1986 water years . . . . . . . . . . . . 9

8. Total macrophyte biomass in Black Earth Creek in reaches 1, 3, and 7, 1985 and $1986 \ldots \ldots 11$

9. Relative frequency of occurrence of macrophyte species in

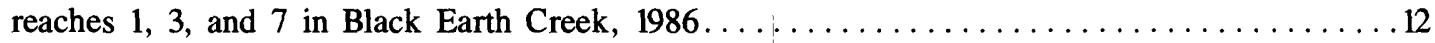

10. Relative frequency of occurrence of macrophyte species in

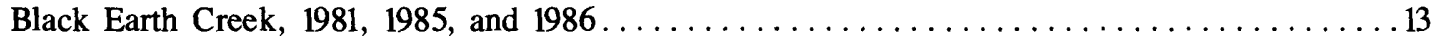

11. Seasonal succession of species in Black Earth Creek, $1986 \ldots \ldots \ldots \ldots \ldots$

12. Relative chemical composition of surface and ground water for Black Earth Creek

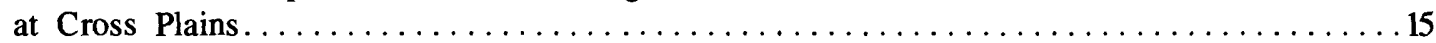

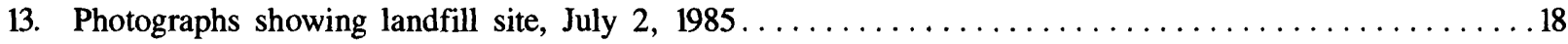

14-22. Graphs showing:

14. Comparison of total phosphorus, suspended-sediment, and total nitrogen loads for partial-record site 4 with those at Garfoot Creek near Cross Plains

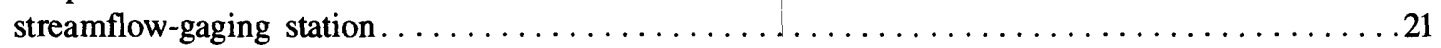

15. Monthly maximum water temperature for Black Earth Creek at Cross Plains and Black Earth

16. Percentage of time maximum daily water temperature was equaled or exceeded,

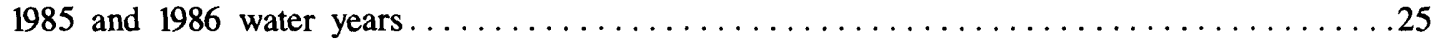

17. Percentage of time summer daily (July-August) maximum water temperature

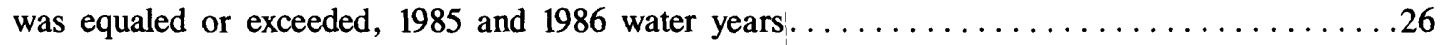

18. Stream stage, temperature, and dissolved-oxygen concentration,

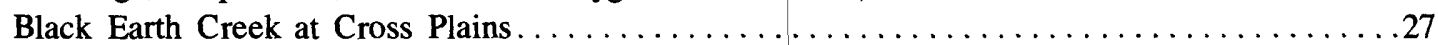

19. Percentage of time daily minimum dissolved-oxygen concentration

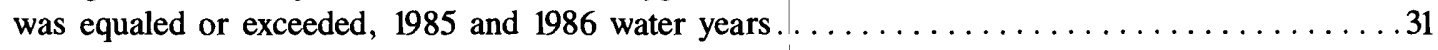

20. Streamflow, water temperature, and dissolved-oxygen concentration,

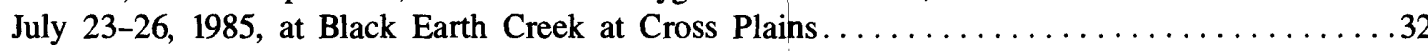

21. Streamflow, annual mean discharge, trout populations, ground-water levels, and cumulative departure of precipitation from normal for Black Earth Creek basin . . . . . . . . . . 34

22. Relation between 3-year moving-mean streamflow and trout populations

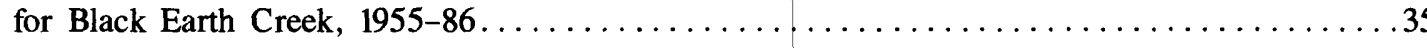




\section{TABLES}

Table 1. Basin characteristics for the Black Earth Creek streamflow-gaging stations.

2. Monthly and yearly precipitation totals for the rain gages in the Black Earth Creek basin,

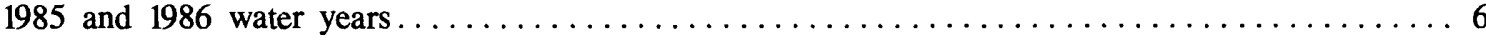

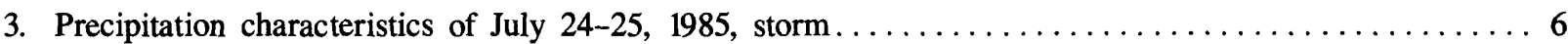

4. Summary of streamflow characteristics for the Black Earth Creek basin

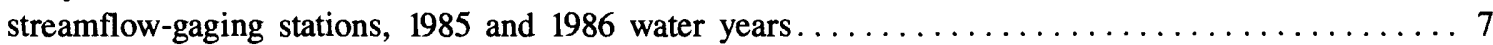

5. Measured discharge during low-flow periods in Black Earth Creek, 1985 and 1986 water years....... 10

6. Maximum instantaneous and minimum 7-day mean low-flow at the Black Earth Creek basin streamflow-gaging stations, and streamflow characteristics at the Black Earth Creek at

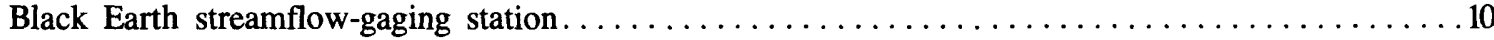

7. Statistical summary of concentrations of suspended sediment and nutrients at the Black Earth Creek basin streamflow-gaging stations $\ldots \ldots \ldots \ldots \ldots \ldots \ldots \ldots \ldots$

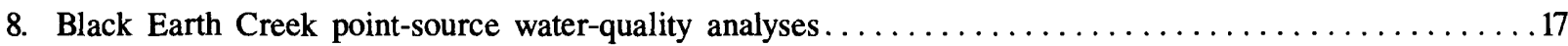

9. Suspended-sediment and nutrient loads and yields for Black Earth Creek basin streamflow-gaging stations and partial-record stations, 1985 and 1986 water years............. 19

10. Annual suspended-sediment loads, yields, and discharges for Black Earth Creek at

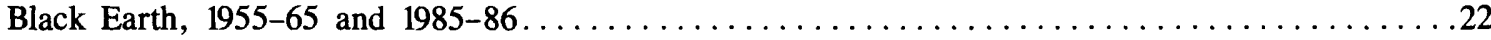

11. Maximum, minimum, and mean water temperatures and dissolved-oxygen concentrations

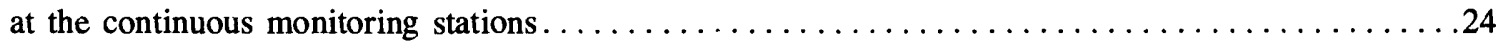

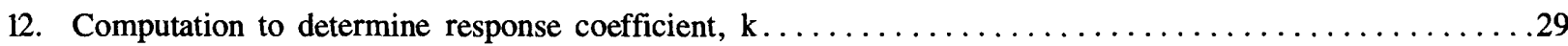

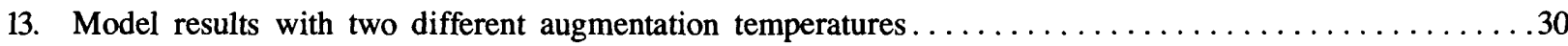


VI

\section{FACTORS FOR CONVERTING INCH-POUND TO METRIC (SI UNITS)}

For the convenience of readers who may prefer to use metric (International Systm) units rather than the inch-pound units used in this report, values may be converted by using the following factors:

Multiply inch-pound unit

inch (in.)

foot (ft)

mile (mi)

square mile $\left(\mathrm{mi}^{2}\right)$

foot per mile $(\mathrm{ft} / \mathrm{mi})$

cubic foot $\left(\mathrm{ft}^{3}\right)$

cubic foot per second

$\left(\mathrm{ft}^{3} / \mathrm{s}\right)$

gallon per day (gal/d)

ton (short)

ton per square mile

(ton/ $\left.\mathrm{mi}^{2}\right)$

pound per square mile

$\left(\mathrm{lb} / \mathrm{mi}^{2}\right)$

acre

pounds dry weight per square foot $\left(\mathrm{lbdw} / \mathrm{ft}^{2}\right)$
By

25.4

0.3048

1.609

0.1894

0.02832

0.02832

0.003785

0.9072

0.3503

0.17513

4,047

4,883
To obtain metric unit

millimeter (mm)

meter (m)

kilometer (km)

square kilometer $\left(\mathrm{km}^{2}\right)$

meter per kilometer $(\mathrm{m} / \mathrm{km})$

cubic meter $\left(\mathrm{m}^{3}\right)$

cubic meter per second $\left(\mathrm{m}^{3 / s}\right)$

cubic meter per day $\left(\mathrm{m}^{3 / \mathrm{d}}\right)$

megagram (mg)

megagram per square kilometer $\left(\mathrm{mg} / \mathrm{km}^{2}\right)$

kilogram per square kilometer $\left(\mathrm{kg} / \mathrm{km}^{2}\right)$

square meter $\left(\mathrm{m}^{2}\right)$

gram dry weight per square meter $\left(\mathrm{gdw} / \mathrm{m}^{2}\right)$

Temperatures are reported in degrees Celsius $\left({ }^{\circ} \mathrm{C}\right)$, and can be converted to degrees Fahrenheit $\left({ }^{\circ} \mathrm{F}\right)$ by $5 / 9 \times\left({ }^{\circ} \mathrm{F}-32\right)$ 


\title{
HYDROLOGY, AQUATIC MACROPHYTES, AND WATER QUALITY OF BLACK EARTH CREEK AND ITS TRIBUTARIES, DANE COUNTY, WISCONSIN, 1985-86
}

\author{
By Stephen J. Field and David J. Graczyk
}

\begin{abstract}
An intensive data-collection program for the Black Earth Creek basin in southern Wisconsin was conducted from October 1984 through September 1986 to assess the hydrology, aquatic macrophytes, and water quality in Black Earth Creek by the U.S. Geological Survey, in cooperation with the Wisconsin Department of Natural Resources. Three sites on two cold-water trout streams-Black Earth Creek at Cross Plains, Black Earth Creek near Cross Plains, and Garfoot Creek near Cross Plains-were continuously monitored for streamflow and water-quality data. One site in a warm-water stream, Brewery Creek at Cross Plains, also was monitored. Aquatic macrophyte biomass was determined for three sites on Black Earth Creek.

Streamflow at Black Earth Creek at Black Earth during the 1985 and 1986 water years (WY) were 44 and 60 percent greater than the long-term mean discharge of $33.3 \mathrm{ft}^{3 /} / \mathrm{s}$ (cubic feet per second) for the period 1955-86. Water year 1986 had the highest annual mean discharge, $53.4 \mathrm{ft}^{3} / \mathrm{s}$, since records began in 1954 at the most downstream site-Black Earth Creek at Black Earth. Although there have been considerable fluctuations in streamflow, it has tended to increase since WY 1965 as a result of above-average precipitation and consequent rising ground-water levels.

Trout population densities may be related to annual mean streamflow. A regression analysis of adult trout populations and the 3-year moving annual mean discharge had a correlation coefficient of 0.75 with a standard error of 83 percent.
\end{abstract}

Aquatic macrophyte biomass in Black Earth Creek was substantially less in 1986 than in 1985 as a result of substrate scouring from the flood of July 25,1985 . The frequency of occurrence of species during 1985 and 1986 was similar to that of 1981, and seasonal succession of species also was similar; Potamogeton crispus dominated early in the year and senesced in July. $P$. crispus and $P$. pectinatus, both indicative of eutrophic conditions, dominated upstream and downstream, respectively; neither species is native to the area. In 1985, the greatest biomass was found upstream from Cross Plains. This large biomass caused diurnal fluctuations in dissolved-oxygen concentration of 5 to $6 \mathrm{mg} / \mathrm{L}$ (milligrams per liter) as a result of photosynthesis and respiration. Many of the dissolved-oxygen minimums, recorded at night, were less than the State $6.0-\mathrm{mg} / \mathrm{L}$ water-quality standard for trout waters.

Discharge from point sources may adversely affect Black Earth Creek's water quality. Warm water discharged to Black Earth Creek from a gravel pit operation upstream from Cross Plains increased water temperatures 2 to 4 degrees Celsius and decreased the dissolved oxygen about $1 \mathrm{mg} / \mathrm{L}$ at a site 1.8 miles downstream. Runoff from a settling pond from a landfill operation in the headwaters of the Black Earth Creek basin drains through a wetland that drains to Black Earth Creek and contained as much as $60 \mathrm{mg} / \mathrm{L}$ ammonia nitrogen, $980 \mathrm{mg} / \mathrm{L}$ biochemical oxygen demand, and 1,300 $\mathrm{mg} / \mathrm{L}$ chemical oxygen demand, which may be detrimental to trout.

Garfoot Creek had the highest suspended-sediment and phosphorus yields per unit area of the three upstream basins during low to moderate runoff. Detention ponds in the Brewery Creek basin appear to be less effective in controlling suspended-sediment and phosphorus loads during periods of high runoff than during moderate runoff. Brewery Creek had the highest concentrations of suspended sediment and total phosphorus during low and high flows. The water quality at the Black Earth Creek gaging station at Black Earth was affected by Garfoot Creek and unnamed tributaries. As a 
result, yields of suspended sediment, phosphorus, and nitrogen increased between Cross Plains and Black Earth. High streamflows during WY 1985 resulted in suspendedsediment yields at Black Earth Creek at Black Earth that were 29 percent greater than the 12-year (1955-65, 85-86) mean; yields ranged from $69.5 \mathrm{ton} / \mathrm{mi}^{2}$ (tons per square mile) in Black Earth Creek at Cross Plains to 116 ton $/ \mathrm{mi}^{2}$ in the Brewery Creek basin. Phosphorus yields ranged from 312 $\mathrm{lb} / \mathrm{mi}^{2}$ (pounds per square mile) in Black Earth Creek at Cross Plains to $628 \mathrm{lb} / \mathrm{mi}^{2}$ in the Brewery Creek basin. Total nitrogen yields ranged from $3,280 \mathrm{lb} / \mathrm{mi}^{2}$ in the Brewery Creek basin to $6,920 \mathrm{lb} / \mathrm{mi}^{2}$ in the Garfoot Creek basin.

An increase in oxygen demand, caused by agricultural runoff, has resulted in reduced dissolved-oxygen content of the water in both Black Earth and Garfoot Creeks. The most substantial reduction occurred at Black Earth Creek at Cross Plains on July 25, 1985, as a result of the largest storm runoff event during the study. A rainfall of 5.54 inches caused streamflow discharges to increase from 9 to $122 \mathrm{ft}^{3} / \mathrm{s}$ and dissolved-oxygen concentrations to decline to $3.0 \mathrm{mg} / \mathrm{L}$; the dissolved-oxygen concentration was less than $6.0 \mathrm{mg} / \mathrm{L}$ for 30 hours.

\section{INTRODUCTION}

\section{Background}

Black Earth Creek is a highly productive trout stream in southern Wisconsin (Brynildson and Mason, 1975) (fig. 1). Trout populations have fluctuated since record collection began in 1954 and a peak population was reached in 1983. Despite this population increase, water-quality data indicate that the stream ecosystem is being stressed. These stresses include sediment accumulation, low dissolved-oxygen concentrations, elevated stream temperatures, and dense macrophyte (submersed aquatic plant) growth.

The water quality of Black Earth Creek downstream from Cross Plains prior to 1968 was degraded by effluent from a sewage-treatment plant (Novitzki, 1973). Fishkills caused by low dissolved-oxygen concentrations were observed during the summers of 1963 through 1967. The low dissolved-oxygen concentrations were caused by the combination of high temperature, low streamflow, and high oxygen demand from dense aquatic macrophytes and sewage effluent. No fishkills have been observed since secondary sewage-treatment facilities were put into operation in 1968.

In 1978, the Wisconsin Legislature enacted the Wisconsin Nonpoint Source Water Pollution Abatement Program. This program provides cost sharing and technical assistance to individual property owners, cities, and villages in "priority watersheds" for the control of nonpoint sources of water pollution. An area must be designated a priority watershed to be eligible for cost sharing and technical assistance under the Wisconsin Fund. In the fall of 1985, the Wisconsin Department of Natural Resources (DNR) selected Black Earth Creek as a priority watershed. The primary water-quality objectives of the Black Earth Creek priority watershed are (1) protection of the cold-water fishery, (2) protection of the warmwater fishery, and (3) rehabilitation of the cold-water fishery (Wisconsin Department of Natural Resources, 1986).

An intensive streamflow, aquatic macrophyte, and water-quality-monitoring program in the Black Earth Creek basin, funded cooperatively by the U.S. Geological Survey and the Wisconsin Department of Natural Resources, was performed from October 1984 through September 1986 (water years (WY) 1985 and 1986). Additional water-quality and fish data were collected by the DNR and the Water Resources Management Workshop of the University of WisconsinMadison (Institute for Environmental Studies, 1986). This information may be obtained by contacting the DNR.

\section{Purpose and Scope}

This report presents results of a study to assess the hydrology, aquatic macrophytes, and water quality in Black Earth Creek and its tributaries. The information presented in the report includes determination of (1) streamflow, (2) aquatic macrophyte species and biomass, (3) suspendedsediment, total phosphorus, and total nitrogen loads, (4) miscellaneous water-quality characteristics, and (5) water temperatures and concentrations of dissolved oxygen.

Four continuous stream-discharge/water-quality sites were monitored (fig. 1): Black Earth Creek at Cross Plains (05406460), Brewery Creek at Cross Plains (05406470), Garfoot Creek at Cross Plains (05406491) and Black Earth Creek at Black Earth (05406500). Several miscellaneous sites were selected for synoptic sampling: five partial-record sites for streamflow (high and low flow) and water-quality (suspended sediment, total phosphorus, and nitrogen species) data, and nine sites for streamflow (only low flow) and waterquality (suspended sediment, total phosphorus, and nitrogen species) data.

Three reaches of stream on Black Earth Creek were selected for identification of aquatic macrophyte species and determination of biomass (fig. 1). These reaches were surveyed previously by Madsen in 1981 (Madsen, 1982).

\section{DESCRIPTIONS OF FISHERY AND PHYSICAL SETTING}

\section{Fishery}

Black Earth Creek is a very productive trout stream and has been managed primarily by the DNR since 1950 . A detailed discussion of the fishery and its history is well documented in a report by the Institute for Environmental Studies (1986). Trout populations have fluctuated since records began in 1954, and a peak population was reached in 1983. Trout population data from 1954-84 are shown in figure 2.

1 Water year. In U.S. Geological Survey reports dealing with surface-water supply, the 12-month period, October 1 through September 30 . The water year is designated by the calendar year in which it ends and which includes 9 of the 12 months. Thus, the year ended September 30, 1985, is called the " 1985 water year." 


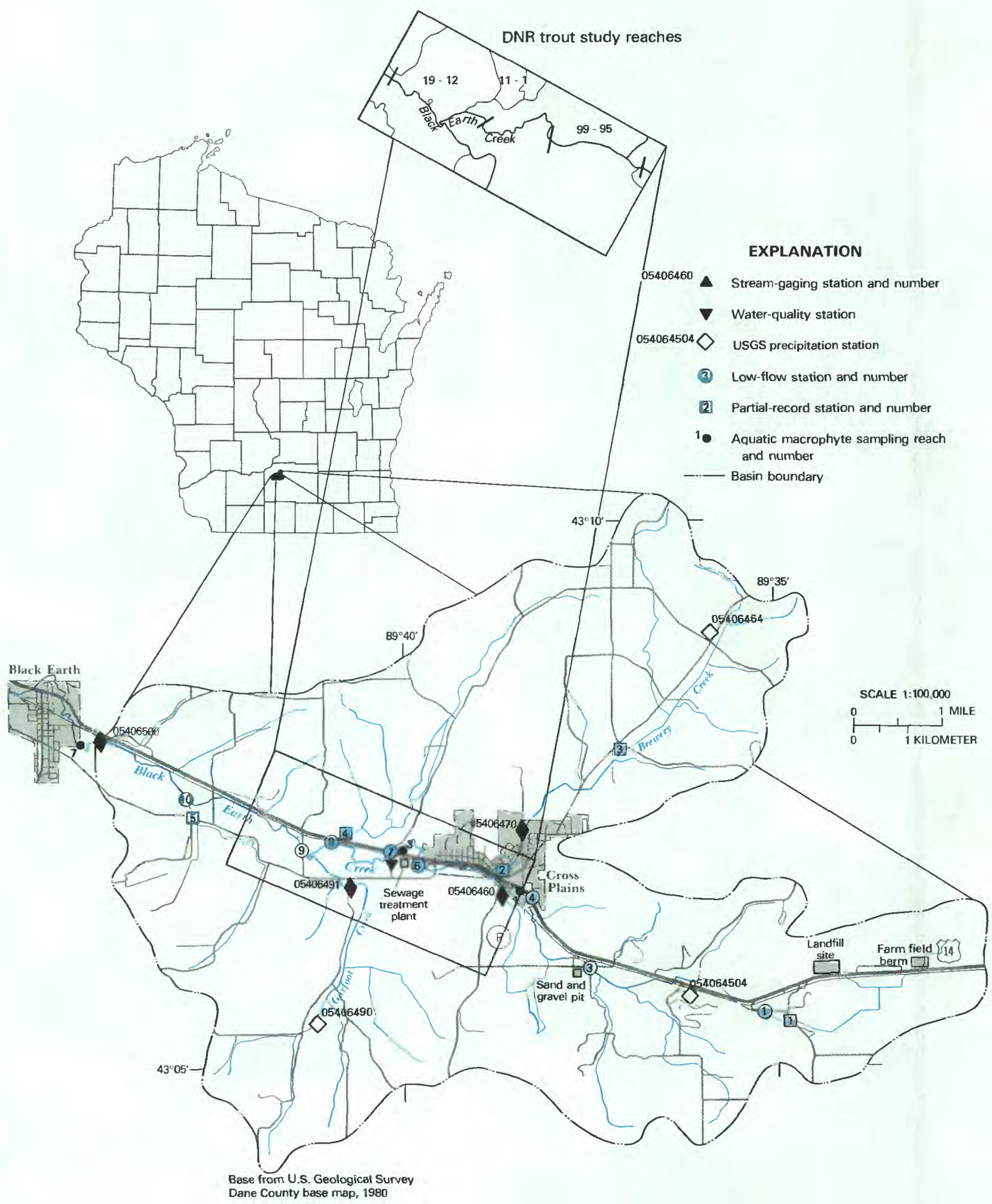

Figure 1. Location of the Black Earth Creek basin in Wisconsin and data-collection sites. 
Most of the streams in the Black Earth Creek basin contain trout. The streams, or reaches of the streams, range from Class I trout waters (capable of natural trout reproduction) to warm-water fisheries (bass, northern pike, panfish, and other species) (Wisconsin Department of Natural Resources, 1980). Black Earth Creek, from about the sandand-gravel pit upstream from of Cross Plains to the mouth of Garfoot Creek, is classified Class I waters. Garfoot Creek to its mouth and Black Earth Creek from its confluence with Garfoot Creek to Black Earth are Class II trout waters. Class II trout waters are those streams in which some natural trout reproduction occurs but require artificial propagation to maintain them. Brewery Creek, other tributaries to Black Earth Creek, and Black Earth Creek downstream from Black Earth are considered warm-water fisheries. Brewery Creek contains mostly minnows (personal observation by the authors).

\section{Topography and Drainage}

The Black Earth Creek basin studied for this report is upstream from the village of Black Earth in northwestern Dane County, Wis. (fig. 1). The drainage area at the most downstream monitoring site is $45.6 \mathrm{mi}^{2}$ (square miles). Black Earth Creek flows westerly into Blue Mounds Creek about $6 \mathrm{mi}$ (miles) west of the village of Black Earth. Blue Mounds Creek is tributary to the Wisconsin River, which is tributary to the Mississippi River. The watershed is hilly and has steepsided valleys. The floor of the main valley of Black Earth Creek between the villages of Cross Plains and Black Earth is nearly flat and about a half-mile wide.

\section{Stream Characteristics}

From its headwaters to the gage near Black Earth, Black Earth Creek winds through a series of pools and riffles for a distance of $14.3 \mathrm{mi}$. The creek's bottom material consists of sand, silt, clay, and cobbles. Garfoot Creek is 3.8 mi long from the headwaters to the gaging station, and Garfoot Creek's streambed is similar to that of Black Earth Creek. Brewery Creek upstream from Cross Plains is $6.1 \mathrm{mi}$ long and has been channelized; its bottom material consists of soft silt and clay.

Channel slopes of the streams studied can be found in figure 3. The average slopes range from $9.56 \mathrm{ft} / \mathrm{mi}$ (feet per mile), for the stream reach of Black Earth Creek from Cross Plains to the basin divide, to $97.2 \mathrm{ft} / \mathrm{mi}$, for the stream reach of Garfoot Creek from the gage to the basin divide. Basin characteristics for the continuous monitoring stations are shown in table 1.

\section{Geology, Soils, and Land Use}

The Black Earth Creek watershed is in the Driftless Area-an area that probably was not glaciated during Pleistocene time. Black Earth Creek flows primarily through unconsolidated outwash and alluvium, mostly sand and gravel that is sorted and stratified (Cline, 1965). The thickness of the unconsolidated material ranges from 50 to $200 \mathrm{ft}$ (feet). The bedrock of the basin is a sedimentary sandstone with some dolomite and shale of Cambrian and Ordovician age (Mudrey, Brown, and Greenburg, 1982).

The Black Earth Creek valley bottom soil is mainly an Otter Silt Loam (Glockler and Patzer, 1978). Soil slopes range from 0 to 2 percent. This soil has a low permeability and a high water table. The valley bottom soil above the Black Earth Creek at Cross Plains gaging station is mostly Elburn Silt Loam with slopes of 0 to 3 percent. The upland soils consist mainly of silt loams with slopes of 0 to 6 percent.

Brewery Creek valley bottom soils are composed of Orion and Otter Silt Loams. Both of these soil types are found along creek bottoms and floodplains. These soils are poorly drained, with slopes of 0 to 2 percent. The upland soils are mainly silt loams of the Dunbarton series with slopes of 6 to 20 percent and the soils are highly erodable.

The valley bottom soils of Garfoot Creek are Otter Silt Loams, and a large area east of the creek is Orion Silt Loam that is poorly drained. Water ponds in concave areas, and the Orion Silt Loam has a slope of 0 to 2 percent. The uplands soils are composed of silt loams that have slopes of 6 to 20 percent and the soils may be highly erodable.

The land use of the Black Earth Creek watershed is mainly agricultural; 72 percent of the watershed is in row crops and pasture, 25 percent is forest, and 3 percent is urban area (Bergen and others, 1985).

\section{DATA-COLLECTION NETWORK}

Gaging stations that continuously monitor streamflow and water temperature were installed in September 1984 at Black Earth Creek at Cross Plains, Brewery Creek at Cross

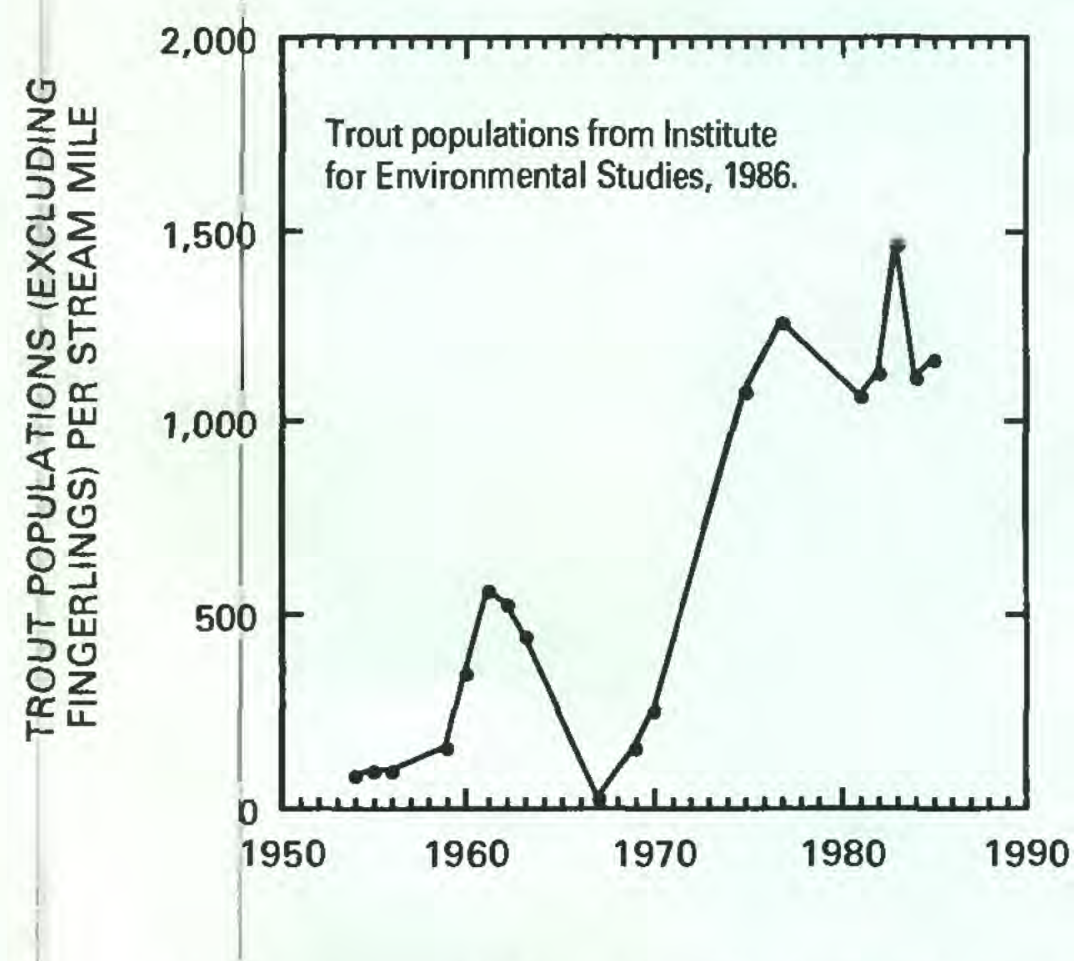

Figure 2. Trout populations in Black Earth Creek, 1954-86, from one-half mile downstream from Garfoot Creek to one-half mile upstream from Cross Plains. 
Plains, and Garfoot Creek near Cross Plains. A continuous water-temperature recorder was also installed at Black Earth Creek at Black Earth, where streamflow has been monitored continuously since 1954 .

Three continuous-recording rain gages were installed in the central parts of the three upstream basins to operate during ice-free periods: Black Earth Creek at Cross Plains (05406460), Brewery Creek (05406470), and Garfoot Creek (05406491) (fig. 1). Data from these stations were supplemented with weather records obtained by the National Weather Service from a station at Truax Field in Madison (U.S. Department of Commerce, 1984, 1985, and 1986).

Refrigerated automatic water samplers were installed at all four sites to collect samples during storm runoff for analyses of suspended-sediment and nutrient concentrations. A local observer collected weekly suspended-sediment samples during nonstorm periods.

Macrophyte surveys were conducted at seven reaches on Black Earth Creek in 1985 and at three reaches in 1986 (fig. 1). The 1986 data were used for reach to reach comparison. The 1985 and 1986 data were also compared to data collected by Madsen in 1981 (Madsen, 1982, 1986; Madsen and Adams, 1985).

Dissolved-oxygen concentrations were monitored on Black Earth Creek at Cross Plains and on Garfoot Creek near Cross Plains during WY 1985. The dissolved-oxygen concentration was continuously monitored by a U.S. Geological Survey minimonitor at Black Earth Creek at Cross Plains and a Yellow Springs Model $5^{2}$ at Garfoot Creek near Cross Plains. The Garfoot Creek site was discontinued during the 1986 water year, and two additional sites on Black Earth Creek were monitored for dissolved oxygen. One site was $0.7 \mathrm{mi}$ downstream from the sewage-disposal plant at Cross Plains at U.S. Highway 14 and County Highway KP, where a U.S. Geological Survey minimonitor was installed, and the

2 Use of trade names in this report is for identification purposes only and does not constitute endorsement by the U.S. Geological Survey.

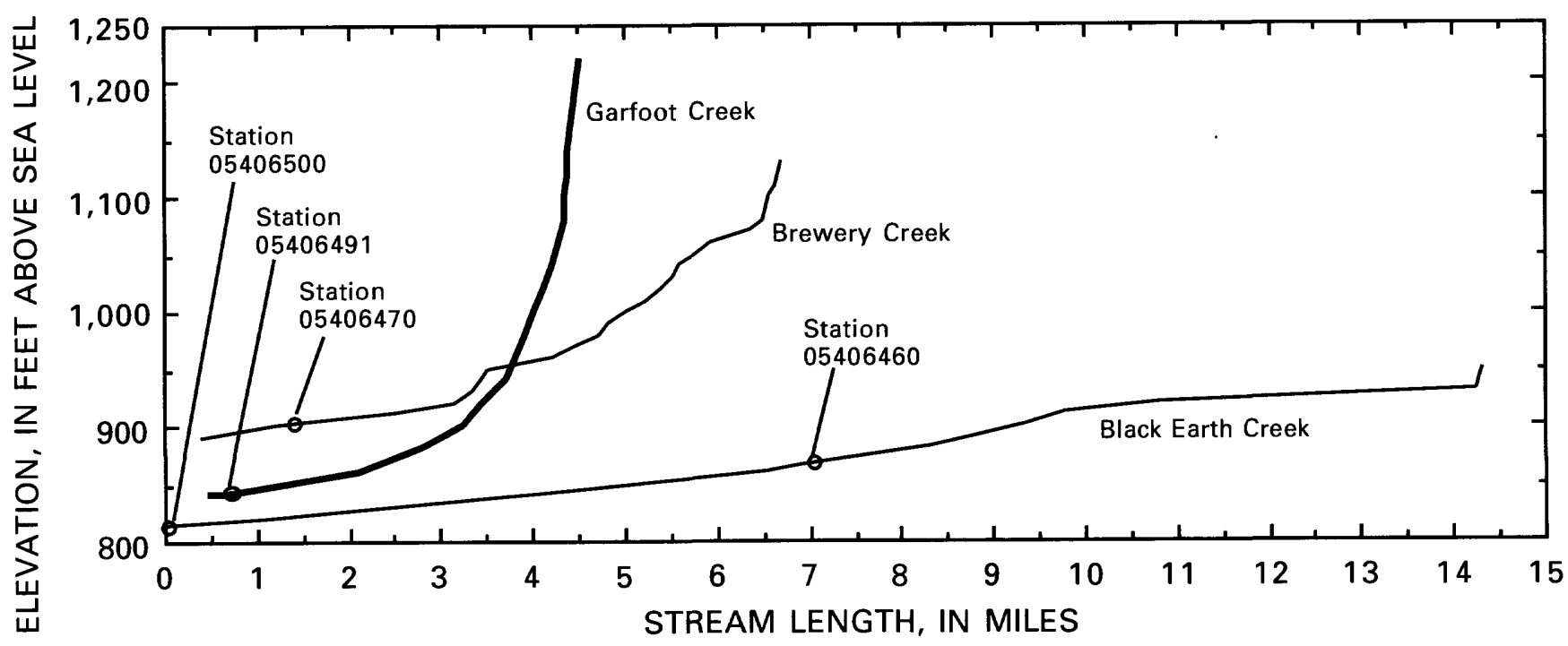

Figure 3. Channel slopes of the study streams.

Table 1.-Basin characteristics for the Black Earth Creek streamflow-gaging stations

$$
[\mathrm{mi}=\mathrm{miles} ; \mathrm{ft} / \mathrm{mi}=\text { foot per mile] }
$$

\begin{tabular}{lcccc}
\hline Basin characteristic & $\begin{array}{c}\text { Black Earth Creek } \\
\text { at Cross Plains } \\
\text { 05406460 }\end{array}$ & $\begin{array}{c}\text { Brewery Creek } \\
\text { at Cross Plains } \\
\mathbf{0 5 4 0 6 4 7 0}\end{array}$ & $\begin{array}{c}\text { Garfoot Creek } \\
\text { near Cross Plains } \\
\mathbf{0 5 4 0 6 4 9 1}\end{array}$ & $\begin{array}{c}\text { Black Earth Creek } \\
\text { near Black Earth } \\
\mathbf{0 5 4 0 6 5 0 0}\end{array}$ \\
\hline Drainage area (mi) & 14.6 & 10.5 & 5.39 & 45.6 \\
Stream length (mi) & 7.40 & 6.13 & 3.87 & 14.32 \\
Channel slope (ft/mi) & 13.8 & 40.3 & 97.2 & 9.56 \\
$\begin{array}{l}\text { Channel slope between } \\
\text { 10 and 85 percent points }\end{array}$ & 9.84 & 33.5 & 46.9 & 9.50 \\
(ft/mi) & & & & \\
\hline
\end{tabular}


other site was at the streamflow-gaging station at Black Earth, where a Yellow Springs Model 56 was installed. Dissolved oxygen was monitored continuously during the open-water period (April through November) in WY 1985 and 1986.

\section{HYDROLOGIC CONDITIONS DURING STUDY PERIOD}

\section{Precipitation}

The long-term (1951-80) annual mean precipitation for the study basin was determined to be 30.8 in. (inches) using data from the U.S. Weather Bureau station at Madison (U.S. Department of Commerce, 1985). Rain gages installed near the central part of each basin (fig. 1) were operated from October 1 through November 21, 1984; March 26 through November 21, 1985; and April 5 through September 30, 1986. The monthly totals from these rain gages and values for the winter months from the U.S. Weather Bureau station at the University of Wisconsin Arboretum in Madison are shown in table 2. Average precipitation during WY 1985 and 1986 was 41.6 and 37.3 in., respectively. All three gages recorded similar precipitation totals during 1985 . However, during WY 1986 the Garfoot Creek gage recorded almost 3 in. more precipitation than did the other two gages.

The single largest rain event during the study period occurred on July 24-25, 1985 . Precipitation characteristics for this storm and daily totals for July 24-25 are shown in table 3.

\section{Streamflow}

The streamflow data collected as part of this study were used to determine the streamflow characteristics at the gaging stations; those characteristics are summarized in table 4. Daily streamflow data from the stations for WY 1985 are published in "Water Resources Data for Wisconsin, Water Year 1985" (Holmstrom and others, 1986) and the data for WY 1986 are published in "Water Resources Data for Wisconsin, Water Year 1986" (Holmstrom and others, 1987).
Table 2.-Monthly and yearly precipitation totals for the rain gages in Black Earth Creek basin, 1985 and 1986 water years

[units are in inches]

\begin{tabular}{|c|c|c|c|c|}
\hline \multirow{2}{*}{$\begin{array}{l}\text { Water } \\
\text { year }\end{array}$} & \multirow[b]{2}{*}{ Month } & \multicolumn{3}{|c|}{ Basin name } \\
\hline & & Black Earth & Brewery & Garfoot \\
\hline \multirow[t]{13}{*}{1985} & October & 7.12 & 6.19 & 6.33 \\
\hline & November & 1.79 & 2.04 & 2.23 \\
\hline & December $^{1}$ & 2.80 & 2.80 & 2.80 \\
\hline & January' & 1.25 & 1.25 & 1.25 \\
\hline & February ${ }^{1}$ & 1.45 & 1.45 & 1.45 \\
\hline & $\operatorname{March}^{3}$ & 1.97 & 1.83 & 1.77 \\
\hline & April & 2.49 & 2.26 & 2.40 \\
\hline & May & 3.74 & 3.55 & 3.04 \\
\hline & June & 3.41 & 4.09 & 3.75 \\
\hline & July & 6.07 & 7.77 & 7.45 \\
\hline & August & 3.38 & 3.52 & 3.64 \\
\hline & September & 5.25 & 5.42 & 5.79 \\
\hline & $\begin{array}{l}\text { Total } \\
\text { Average }=41.60\end{array}$ & 40.72 & 42.17 & 41.90 \\
\hline \multirow[t]{13}{*}{1986} & October & 4.28 & 4.22 & 4.65 \\
\hline & November $^{4}$ & 4.54 & 4.34 & 4.78 \\
\hline & December ${ }^{1}$ & 3.49 & 3.49 & 3.49 \\
\hline & January'1 & .86 & .86 & .86 \\
\hline & February ${ }^{1}$ & 1.18 & 1.18 & 1.18 \\
\hline & March & 1.28 & 1.28 & 1.28 \\
\hline & April & 2.81 & 2.94 & 2.77 \\
\hline & May & 3.06 & 3.08 & 3.43 \\
\hline & June & 2.54 & 3.02 & 3.14 \\
\hline & July $^{2}$ & 2.71 & 2.66 & 4.14 \\
\hline & August ${ }^{2}$ & 3.50 & 3.50 & 3.50 \\
\hline & September ${ }^{2}$ & 5.98 & 5.98 & 5.98 \\
\hline & $\begin{array}{l}\text { Total } \\
\text { Average }=37.33\end{array}$ & 36.23 & 36.55 & 39.20 \\
\hline
\end{tabular}

'Monthly total December-February data from Arboretum, University of Wisconsin, Madison, U.S. Weather Bureau station.

2July 23 to September 30 used station 05406490

${ }^{3}$ March 1-25 used data from Arboretum, University of Wisconsin, Madison, U.S. Weather Bureau station.

${ }^{4}$ November 22-30 used data from Arboretum, University of Wisconsin, Madison, U.S. Weather Bureau station.

Table 3.-Precipitation characteristics for July 24-25, 1985, storm

\begin{tabular}{|c|c|c|c|c|c|c|c|c|}
\hline \multirow{3}{*}{ Rain gage } & \multirow{3}{*}{$\begin{array}{c}\text { July } 24 \\
\begin{array}{c}\text { Daily } \\
\text { total } \\
\text { (inches) }\end{array}\end{array}$} & \multirow{3}{*}{ 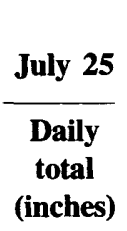 } & \multicolumn{6}{|c|}{$\begin{array}{c}\text { July } 25 \\
\text { Precipitation (inches) }\end{array}$} \\
\hline & & & \multicolumn{6}{|c|}{ Time (hours) } \\
\hline & & & 0045 & 0100 & 0115 & 0130 & 0145 & 0200 \\
\hline $\begin{array}{c}\text { Black Earth Creek } \\
\text { at Cross Plains }\end{array}$ & 2.16 & 3.38 & 0.23 & 0.75 & 0.29 & 0.29 & 0.20 & 0.16 \\
\hline Brewery Creek & 1.57 & 5.29 & .10 & 51 & .74 & .56 & .47 & .34 \\
\hline Garfoot Creek & 2.36 & 4.20 & .30 & .56 & .44 & .38 & .34 & .17 \\
\hline
\end{tabular}




\section{Comparison of Streamflow during 1985 and 1986 Water Years}

On the basis of the discharges observed at Black Earth Creek at Black Earth from WY 1955-86, the annual mean discharge during WY 1985 was 44 percent greater than the long-term mean and the annual mean discharge during WY 1986 was 60 percent greater than the mean. The annual mean discharge during WY 1986 was $53.4 \mathrm{ft}^{3} / \mathrm{s}$-the highest since discharge monitoring began. Although there have been large fluctuations in annual mean discharge, ranging from a low of $19.8 \mathrm{ft}^{3} / \mathrm{s}$ in WY 1964 to a high in WY 1986, the annual mean discharge trend has been increasing since 1965 (fig. 4).

Annual mean discharges during WY 1986 at the four gaging stations were greater than those during WY 1985 even though the annual precipitation in the basins in 1986 averaged 4.27 in. less than in 1985. This difference in stream discharge can be explained by increased ground-water seepage during low flow.

Hydrograph separations, based on a technique described by Linsley, Kohler, and Paulhus (1975), were made for Black Earth Creek at Black Earth (05406500) and Brewery Creek at Cross Plains (05406470) to explain the increased streamflow during WY 1986 despite the lower precipitation. Base flow represents ground-water discharge to the stream channel; surface runoff is that water that flows overland and enters the stream. Base flow calculated on the basis of the separations shown in figure 5 indicate that base flow increased 23 percent in Black Earth Creek and 83 percent in Brewery Creek in WY 1986. Surface runoff in WY 1986 was 38 percent less in Black Earth Creek and 49 percent less in Brewery Creek than in WY 1985. The decrease in surface runoff is caused by the smaller amount of precipitation during WY 1986 compared to WY 1985, whereas the increase in base flow is apparently related to high water-table

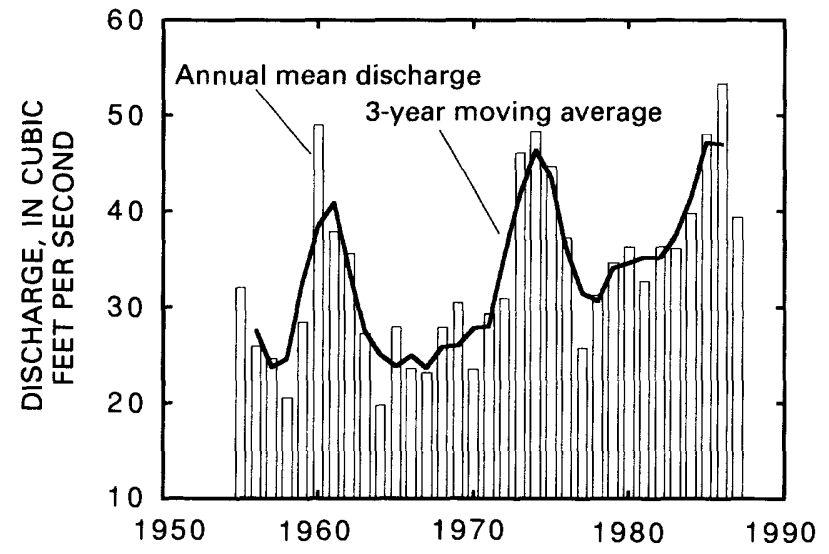

Figure 4. Annual mean streamflow in Black Earth Creek, 1955-86 water years.

Table 4.-Summary of streamflow characteristics for the Black Earth Creek basin streamflow-gaging stations, 1985 and 1986 water years

[D.A. $=$ drainage area in square miles; $-=$ not applicable]

\begin{tabular}{|c|c|c|c|c|c|c|c|c|c|}
\hline \multirow[t]{2}{*}{ Streamflow characteristic } & \multicolumn{2}{|c|}{$\begin{array}{c}\text { Black Earth Creek } \\
\text { at Cross Plains } \\
\text { D.A. }=\mathbf{1 4 . 6}\end{array}$} & \multicolumn{2}{|c|}{$\begin{array}{l}\text { Brewery Creek } \\
\text { at Cross Plains } \\
\text { 'D.A. }=\mathbf{1 0 . 5}\end{array}$} & \multicolumn{2}{|c|}{$\begin{array}{c}\text { Garfoot Creek } \\
\text { near Cross Plains } \\
\text { D.A. }=\mathbf{5 . 3 9}\end{array}$} & \multicolumn{3}{|c|}{$\begin{array}{c}\text { Black Earth Creek } \\
\text { at Black Earth } \\
\text { 2D.A. }=\mathbf{4 5 . 6}\end{array}$} \\
\hline & 1985 & 1986 & 1985 & 1986 & 1985 & 1986 & 1985 & 1986 & $\begin{array}{c}\text { Period of record } \\
1954-86\end{array}$ \\
\hline $\begin{array}{l}\text { Annual mean discharge, in } \\
\text { cubic feet per second }\end{array}$ & 16.1 & 17.6 & 2.73 & 3.01 & 5.26 & 6.35 & 48.1 & 53.4 & 33.3 \\
\hline $\begin{array}{l}\text { Annual mean discharge, in } \\
\text { cubic feet per second per } \\
\text { square mile }\end{array}$ & 1.10 & 1.21 & .35 & .39 & .98 & 1.00 & 1.06 & 1.17 & .78 \\
\hline Runoff, in inches & 15.01 & 16.39 & 4.81 & 5.31 & 13.25 & 16.0 & 15.26 & 16.94 & 10.57 \\
\hline $\begin{array}{l}\text { Minimum 7-day mean low-flow, } \\
\text { in cubic feet per second }\end{array}$ & 10.0 & 12.0 & .93 & 1.9 & 3.0 & 4.5 & 29.0 & 37.0 & 13 \\
\hline $\begin{array}{l}\text { Maximum recorded peak } \\
\text { discharge, in cubic } \\
\text { feet per second }\end{array}$ & 122 & 45.0 & 231 & 33.0 & 128 & 80 & 710 & 236 & 1,750 \\
\hline $\begin{array}{l}\text { Total discharge, in cubic } \\
\text { feet per second }\end{array}$ & 5,890 & 6,430 & 996 & 1,250 & 1,920 & 2,320 & 17,600 & 1,950 & - \\
\hline
\end{tabular}

${ }^{1}$ Includes 2.82 miles noncontributing.

${ }^{2}$ Includes 2.8 miles noncontributing. 


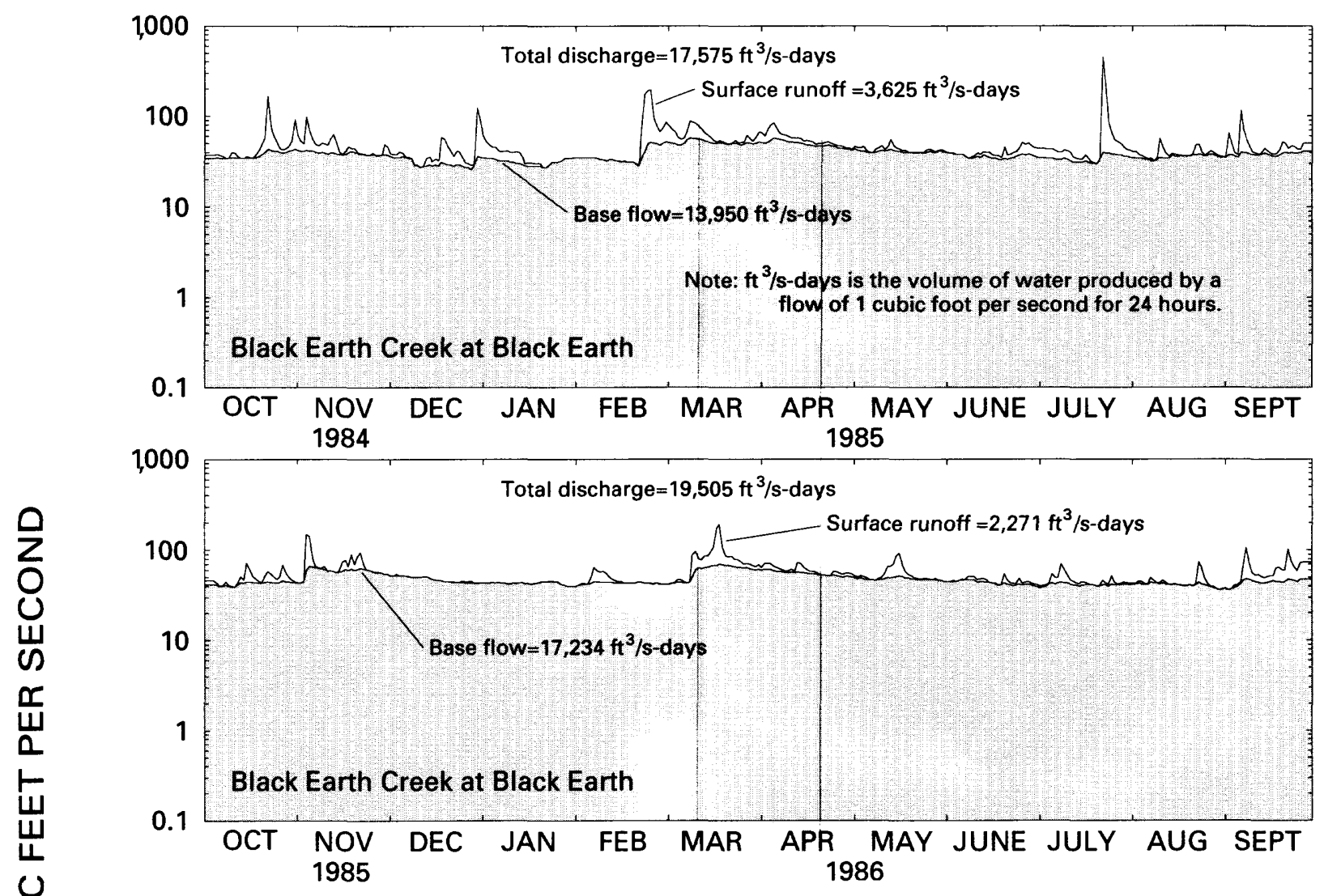

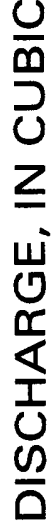

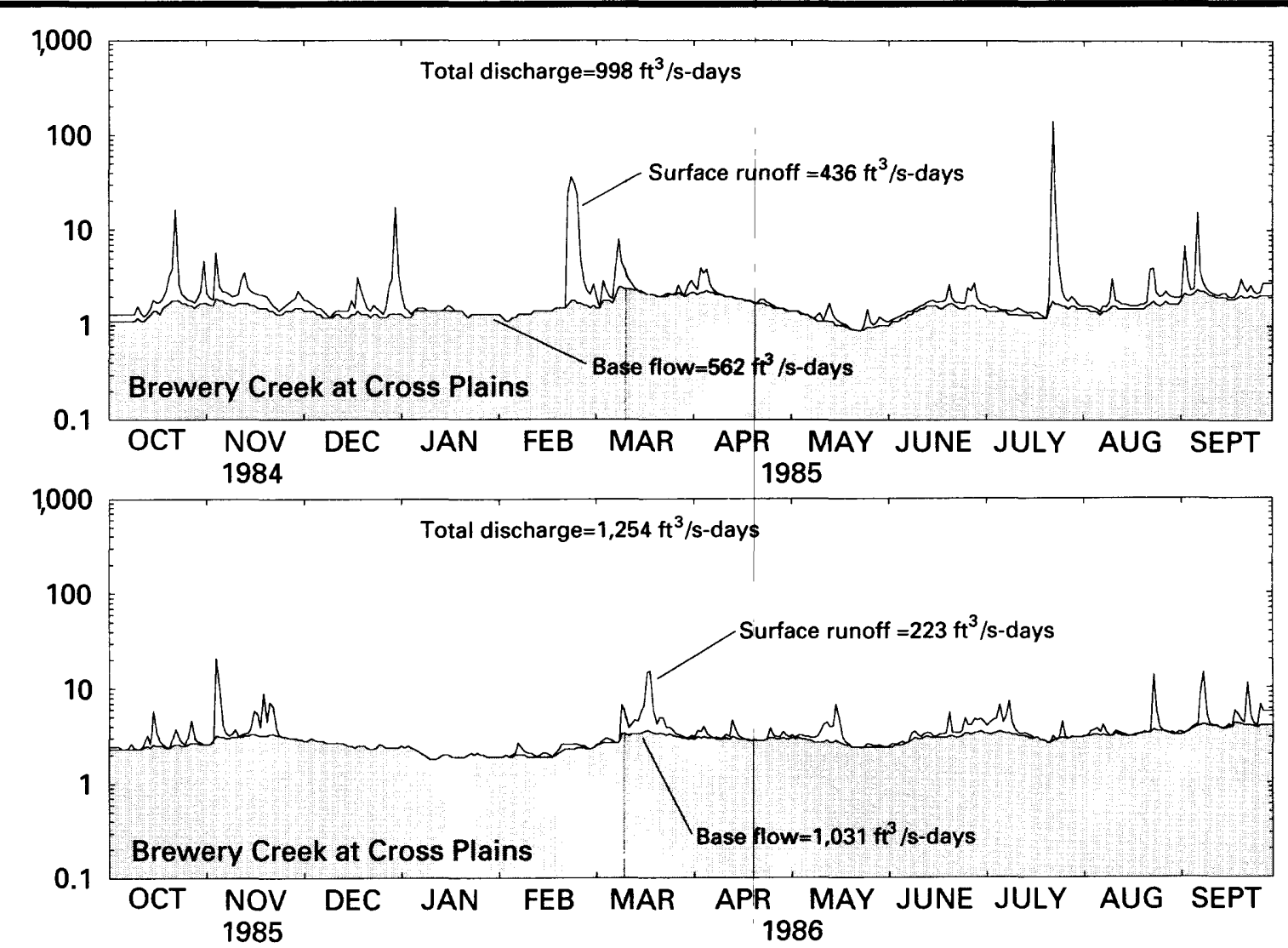

Figure 5. Base flow and surface runoff for Black Earth Creek at Black Earth and Brewery Creek at Cross Plains, 1985 and 1986 water years. 
conditions. This is illustrated by the hydrograph for an observation well (Iw-110) located $10 \mathrm{mi}$ west of the Black Earth Creek streamflow-gaging station (05406500) (fig. 6).

The increased ground-water discharge to the streams (base flow) is illustrated in figure 7 and table 5. Table 5 shows an average 47 percent increase in low flow during WY 1986 compared to WY 1985. Figure 7 shows that most groundwater discharge enters the stream just upstream from Cross Plains between stations LF-3 and 05406460, and that downstream from these stations ground-water discharge per stream mile generally decreases in a downstream direction. (The large increase in discharge between station LF-8 and

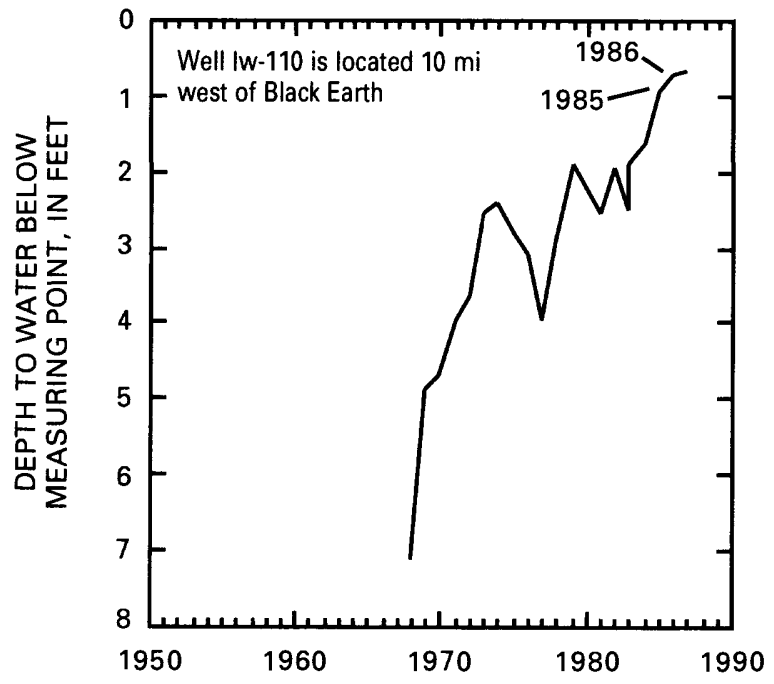

Figure 6. Annual mean water level in observation well Iw-110.
LF-9 is because of Garfoot Creek entering Black Earth Creek.) These data compare well to those reported by Novitzki (1973).

\section{Maximum- and Minimum-Flow Characteristics}

The streamflow extremes that occurred during the study period are shown in table 6. These data are compared to the long-term data from the gaging station Black Earth Creek at Black Earth. The maximum instantaneous discharge that occurred at the Black Earth Creek at Black Earth gaging station was $710 \mathrm{ft}^{3} / \mathrm{s}$ (cubic feet per second), which is equivalent to a flood-recurrence interval of about 5 years, based on 1954-86 data. The maximum instantaneous discharge $\left(236 \mathrm{ft}^{3} / \mathrm{s}\right)$ during WY 1986 was considerably less than a storm recurrence interval of 2 years $(\mathrm{Q} 2)\left(456 \mathrm{ft}^{3} / \mathrm{s}\right)$. The annual minimum 7-day mean flow of $31 \mathrm{ft}^{3} / \mathrm{s}$ during WY 1985 is at the 30-percent flow-duration point. This is almost double the Q2 7-day low flow that occurs on the average of once in 2 years or has a 50-percent chance of occurring in any given year and is approximately equal to the 93 percent flow-duration point (Gebert, 1971).

\section{AQUATIC MACROPHYTES}

\section{By John D. Madsen3, Michael S. Adams3, and William Kleindl ${ }^{3}$}

Aquatic macrophytes (submersed plants) play several roles in a stream's ecosystem. Aquatic macrophytes provide habitat for aquatic insects and other small invertebrates that are eaten by fish. Macrophytes shelter young fish, and plant-

${ }^{3}$ Department of Botany, University of Wisconsin, Madison.

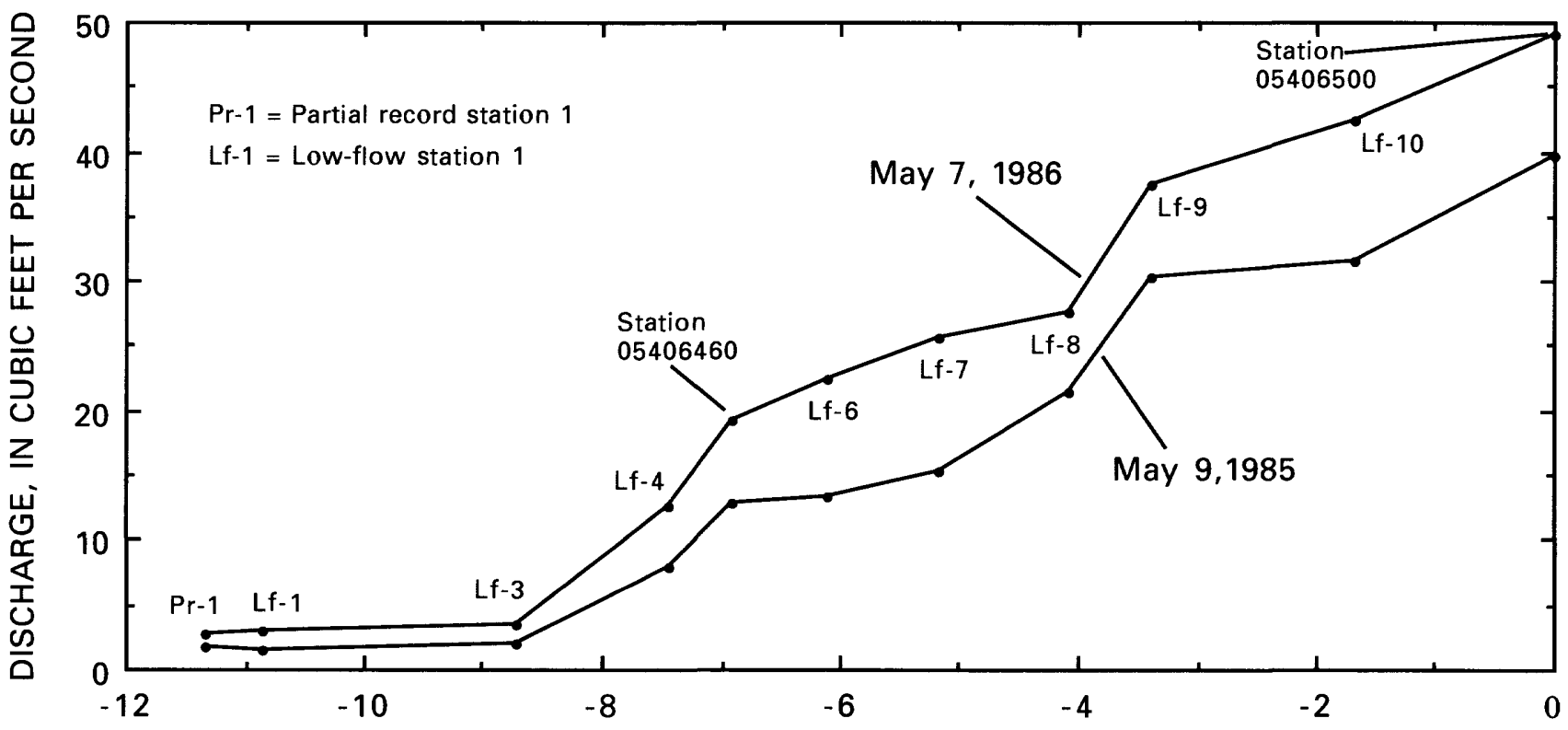

STREAM LENGTH, IN MILES UPSTREAM FROM BLACK EARTH CREEK AT BLACK EARTH

Figure 7. Black Earth Creek low-flow discharge, 1985 and 1986 water years. 
growth patterns affect where fish congregate in a stream. Macrophytes also affect the chemical quality of stream water through photosynthesis and respiration. Species identification and determination of biomass of the aquatic macrophytes of Black Earth Creek were done in 1985 by J. D. Madsen, University of Wisconsin, Madison, in cooperation with the
DNR, and in 1986 by the U.S. Geological Survey. Madsen had also surveyed the plant communities of Black Earth Creek in 1981 (Madsen, 1982). Comparisons were made between 1985,1986 , and 1981 data. No previous quantitative work on species or biomass has been done.

Table 5.-Measured discharge during low-flow periods in Black Earth Creek, 1985 and 1986 water years

[units are in cubic feet per second]

\begin{tabular}{|c|c|c|c|c|c|c|c|c|c|c|c|}
\hline Date & $\begin{array}{l}\text { Partial- } \\
\text { record } \\
\text { site } 1\end{array}$ & $\begin{array}{c}\text { Low-flow } \\
\text { site } 1\end{array}$ & $\begin{array}{c}\text { Low-flow } \\
\text { site } 3\end{array}$ & $\begin{array}{c}\text { Low-flow } \\
\text { site } 4\end{array}$ & $\begin{array}{c}\text { Black Earth Creek } \\
\text { at Cross Plains } \\
05406460\end{array}$ & $\begin{array}{c}\text { Low-flow } \\
\text { site } 6\end{array}$ & $\begin{array}{c}\text { Low-flow } \\
\text { site } 7\end{array}$ & $\begin{array}{c}\text { Low-flow } \\
\text { site } 8\end{array}$ & $\begin{array}{c}\text { Low-flow } \\
\text { site } 9\end{array}$ & $\begin{array}{l}\text { Low-flow } \\
\text { site } 10\end{array}$ & $\begin{array}{c}\text { Black Earth Creek } \\
\text { at Black Earth } \\
05406500\end{array}$ \\
\hline $\begin{array}{l}\text { Drainage area } \\
\text { (square miles) }\end{array}$ & 3.32 & 3.76 & 9.53 & 11.3 & 14.6 & 26.1 & 26.7 & 27.0 & 39.1 & 40.6 & 45.6 \\
\hline \multicolumn{12}{|c|}{1985 water year } \\
\hline Jan. 29, 1985 & 1.53 & 1.71 & 1.83 & 7.21 & 10.6 & 12.5 & 15.7 & 18.1 & 26.2 & 29.8 & 35.4 \\
\hline May 9, 1985 & 1.68 & 1.60 & 1.87 & 7.86 & 12.7 & 13.3 & 15.3 & 21.4 & 30.2 & 31.5 & 39.6 \\
\hline \multicolumn{12}{|c|}{1986 water year } \\
\hline Dec. 11,1985 & 2.31 & 2.65 & 3.13 & 13.73 & 18.3 & 22.3 & 25.0 & 29.0 & 39.2 & 41.0 & 49.8 \\
\hline Feb. 19, 1986 & 2.07 & 2.24 & 2.50 & 5.49 & 15.3 & 19.8 & 23.0 & 26.9 & 36.5 & 41.4 & 43.7 \\
\hline May 7, 1986 & 2.72 & 3.01 & 3.48 & 12.6 & 19.3 & 22.3 & 25.6 & 27.6 & 37.4 & 42.3 & 49.0 \\
\hline
\end{tabular}

Table 6.-Maximum instantaneous and minimum 7-day mean low flow at the Black Earth Creek basin streamflowgaging stations, and streamflow characteristics at the Black Earth Creek at Black Earth streamflow-gaging station [units in cubic feet per second]

\begin{tabular}{lcccc}
\hline & $\begin{array}{c}\text { Black Earth Creek } \\
\text { at Cross Plains }\end{array}$ & $\begin{array}{c}\text { Brewery Creek } \\
\text { at Cross Plains }\end{array}$ & $\begin{array}{c}\text { Garfoot Creek } \\
\text { near Cross Plains }\end{array}$ & $\begin{array}{c}\text { Black Earth Creek } \\
\text { at Black Earth }\end{array}$ \\
\hline Maximum instantaneous discharge & 122 & 1985 water year & & \\
Minimum 7-day mean discharge & 10 & 231 & 128 & 310 \\
& & 1986 water year & 3.0 & 236 \\
Maximum instantaneous discharge & 45 & 33 & 80 & 37 \\
Minimum 7-day mean discharge & 12 & 1.9 & 4.5 & 31 \\
\hline
\end{tabular}

Streamflow characteristics for Black Earth Creek at Black Earth

[units in cubic feet per second]

\begin{tabular}{cccccccccc}
\hline & & \multicolumn{6}{c}{ Flood peaks (1954-86 water years) } \\
\cline { 3 - 9 } $\begin{array}{l}\text { Average } \\
\text { discharge }\end{array}$ & $\mathbf{Q}_{7,2}$ & $\mathbf{Q}_{\mathbf{7 , 1 0}}$ & $\mathbf{2}$ year & $\mathbf{5}$ year & $\mathbf{1 0}$ year & 25 year & $\mathbf{5 0}$ year & $\mathbf{1 0 0}$ year \\
\hline 33 & 20 & 14 & 456 & 754 & 968 & 1,250 & 1,470 & 1,690 \\
\hline
\end{tabular}




\section{Methods}

In each sample reach, 20 biomass samples were collected by a stratified-random pattern, sorted by species, and dried at $70{ }^{\circ} \mathrm{C}$ (degrees Celsius) to a constant weight. Biomass samples were collected on three dates during the summer of 1986: June 23, July 15, and August 7 . The relative frequency of each species, which is a measure of dominance, was calculated as a percentage of total biomass in 1986, and as a percentage of plant cover in 1981 and 1985 . Relative frequency determined from biomass is comparable to, but not the same as, relative frequency determined from plant cover. Although these values are compared, no statistical tests are used in the comparison of relative frequency data due to this difference.

Species nomenclature is based on Gleason and Cronquist (1963), although Fassett (1957) and Voss (1972) were used for initial identification. Sample specimens were deposited in the University of Wisconsin-Madison herbarium.

\section{Total Biomass}

Black Earth Creek is capable of supporting high levels of plant biomass, comparable to some of the highest values reported in the literature (Madsen, 1986). Macrophyte study reaches are shown in figure 1. Biomass values as high as 789 $\mathrm{gdw} / \mathrm{m}^{2}$ (grams dry weight per square meter) at reach 1 (fig. 8) upstream from the sewage-treatment plant in Cross Plains showed that the creek has ample nutrients and substrate available to support dense growth of aquatic plants. Nutrient uptake studies in lakes have shown that macrophytes derive most of their nutrients from the stream substrate (Carignan and Kalff, 1979, Barko and Smart, 1981); very few nutrients are derived from the water column. However, in streams most of the nutrients in the substrate are transported by sediments during storms and deposited from the water column.

Total submersed macrophyte biomass was higher at reaches 1 and 7 in July 1985 than in June 1986 (789 and 512 compared to 323 and $19 \mathrm{gdw} / \mathrm{m}^{2}$, respectively); but little variation occurred in reach 3 between the years ( 335 compared to $347 \mathrm{gdw} / \mathrm{m}^{2}$, respectively) (fig. 8). This wide divergence in biomass is because of channel scour and biomass removal from flooding resulting from the major storm on July 25 , 1985. The flood is suspected to have scoured the soft sediments at reaches 1 and 7, removing both the emerging plant shoots and the plants that had not yet emerged, resulting in lower biomass the following year. Reach 3, with its more stable gravel substrate, was relatively unaffected by scour.

Biomass in reaches 1 and 3 reached maximum growth in late June (fig. 8) because of the early phenology of its dominant species, $P$. crispus, which peaks in mid-June and senesces by mid-July (Sastroutomo, 1981). P. pectinatus is the dominant species in reach 7 (fig. 9), and it peaks in August $\left(134 \mathrm{gdw} / \mathrm{m}^{2}\right)$. P. pectinatus also was dominant in nearby Badfish Creek (Madsen, 1986), about $25 \mathrm{mi}$ southeast of

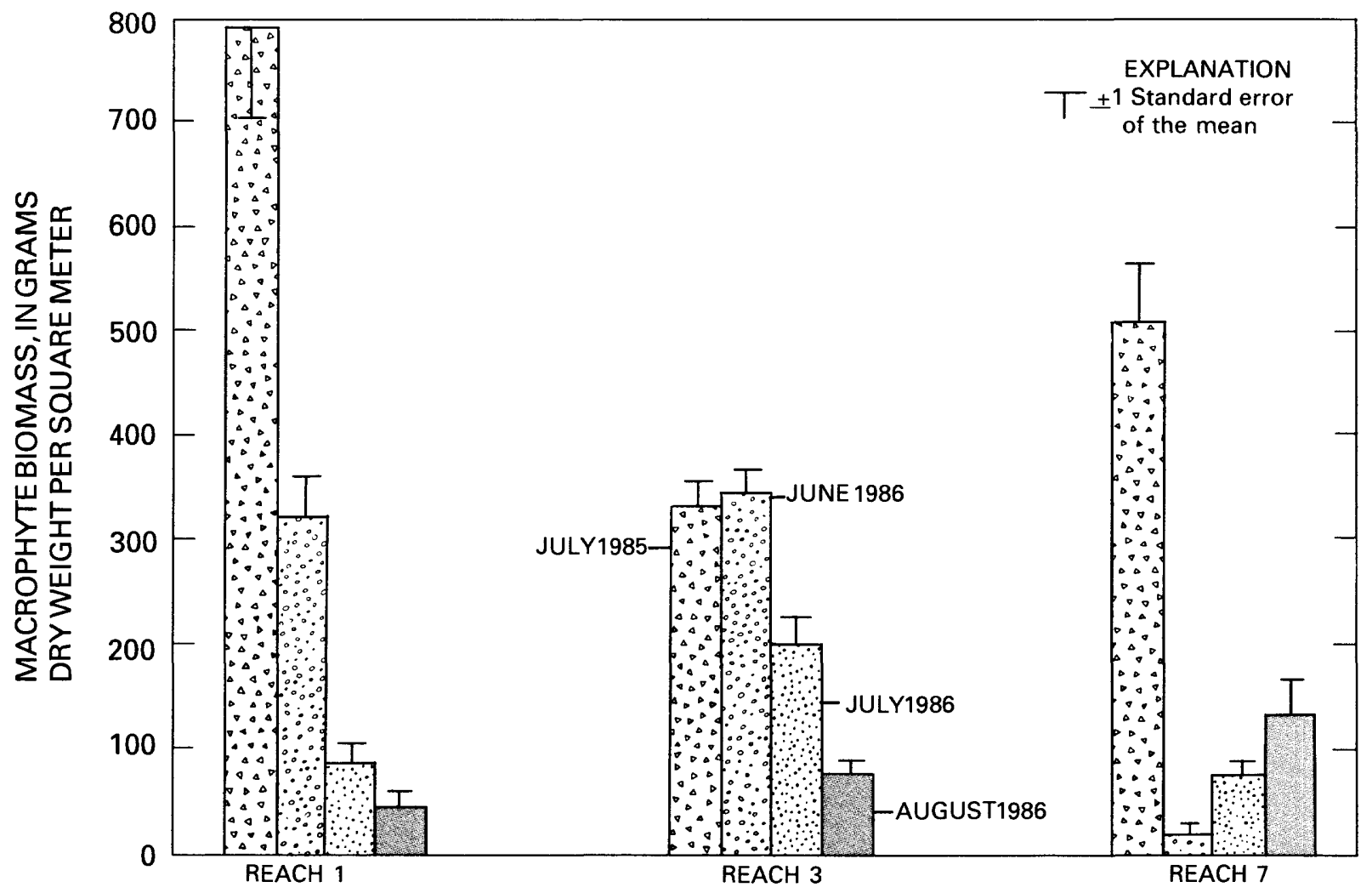

Figure 8. Total macrophyte biomass in Black Earth Creek in reaches 1, 3, and 7, 1985 and 1986. 


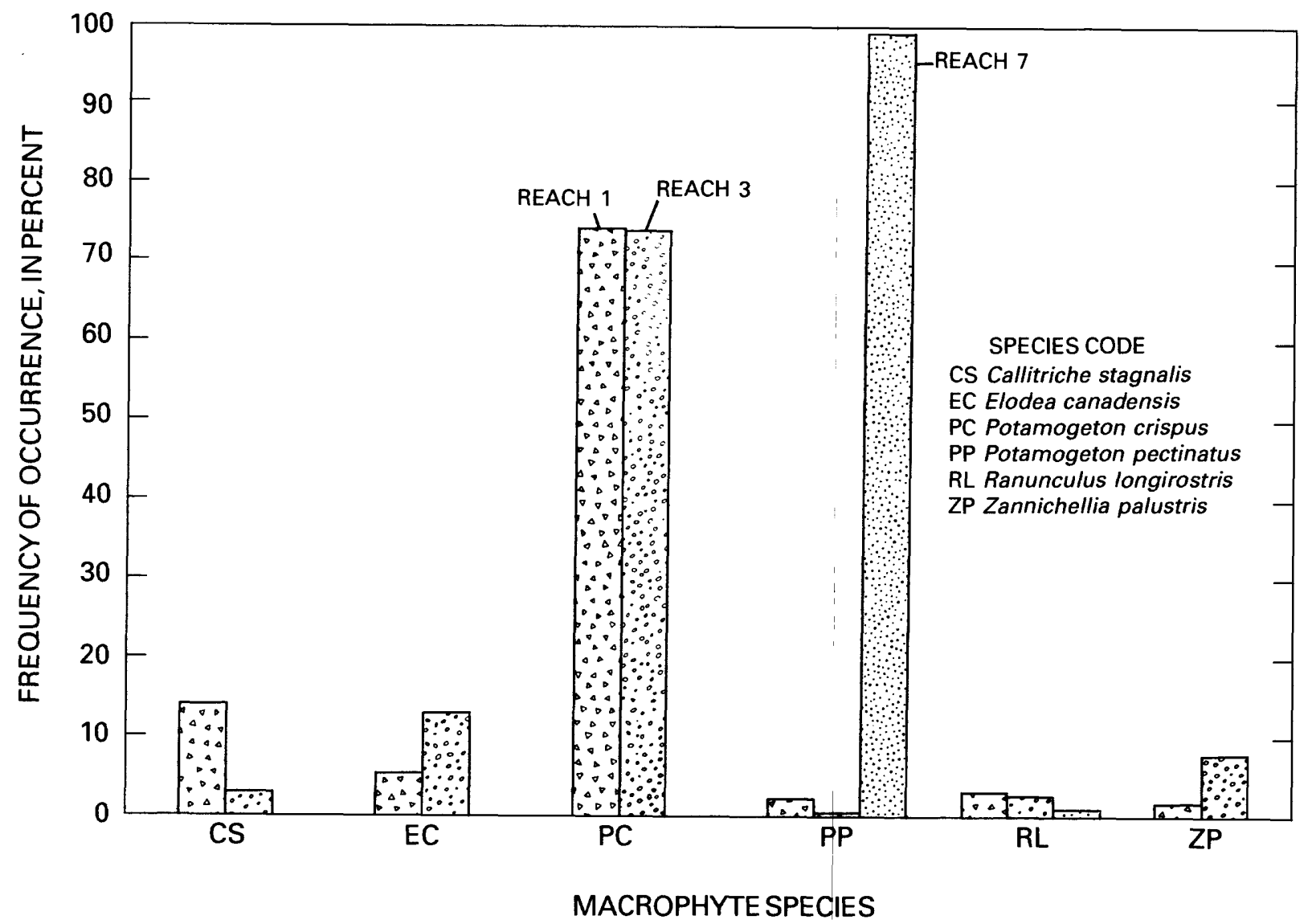

Figure 9. Relative frequency of occurrence of macrophyte species in reaches 1,3 , and 7 in Black Earth Creek, 1986.

Black Earth Creek. Badfish Creek receives the effluent waters of a sewage-treatment plant, which serves the city of Madison.

\section{Species Dominance}

Species observed in Black Earth Creek in 1986 were: Callitriche stagnalis Scop. (waterstarwort), Elodea canadensis Michx. (elodea), Potamogeton crispus L. (curlyleaf pondweed), Potamogeton pectinatus L. (sago pondweed), Ranunculus longirostris Godr. (whitewater crowfoot), and Zannichellia palustris $\mathrm{L}$. (horned pondweed). The relative frequency of occurrence of species has varied little over a 5-year period (1981-86) despite the large variation in total biomass (fig. 10). The species $P$. crispus and $P$. pectinatus have remained dominant throughout the period, although other distinct but minor changes in species occurrence were observed. E. canadensis composed less than 1 percent of total cover in reaches 1 and 3 in 1981, but was frequently found in those reaches in 1985 and 1986 (Bouchard and Madsen, 1987).

Drastic changes in the species composition of Black Earth Creek could result from changes in the light regime. Open stretches, which are common, tend to form the highest biomass and are dominated by either $P$. crispus or $P$. pectinatus. A more diverse community with lower biomass would result if trees and bushes were allowed to grow on the streambanks, thereby limiting the availability of light. This plant-management strategy could be used if macrophyte biomass were considered so high as to be harmful to the trout fishery (Institute for Environmental Studies, 1986; Bouchard and Madsen, 1987). However, it should be noted that a certain amount of macrophyte biomass is desirable (White and Brynildson, 1967; Hunt, 1979).

Streambanks are more stable when held in place by grasses, but grass density decreases with increased shading. Therefore, increased shading may decrease grass density and macrophyte density but may also increase bank instability.

\section{Distribution Between Reaches}

Species dominance of the macrophyte community changed downstream. $P$. crispus dominated in reaches 1 and 3, but $P$. pectinatus dominated in reach 7 (fig. 9). P. pectinatus is often the only species in warmer eutrophic streams (Madsen, 1986) whereas P. crispus tends to be the dominant species in cooler eutrophic environments. The dominance of $P$. crispus in reaches 1 and 3 is consistent with observations made in 1981 and 1985 (Bouchard and Madsen, 1987). 


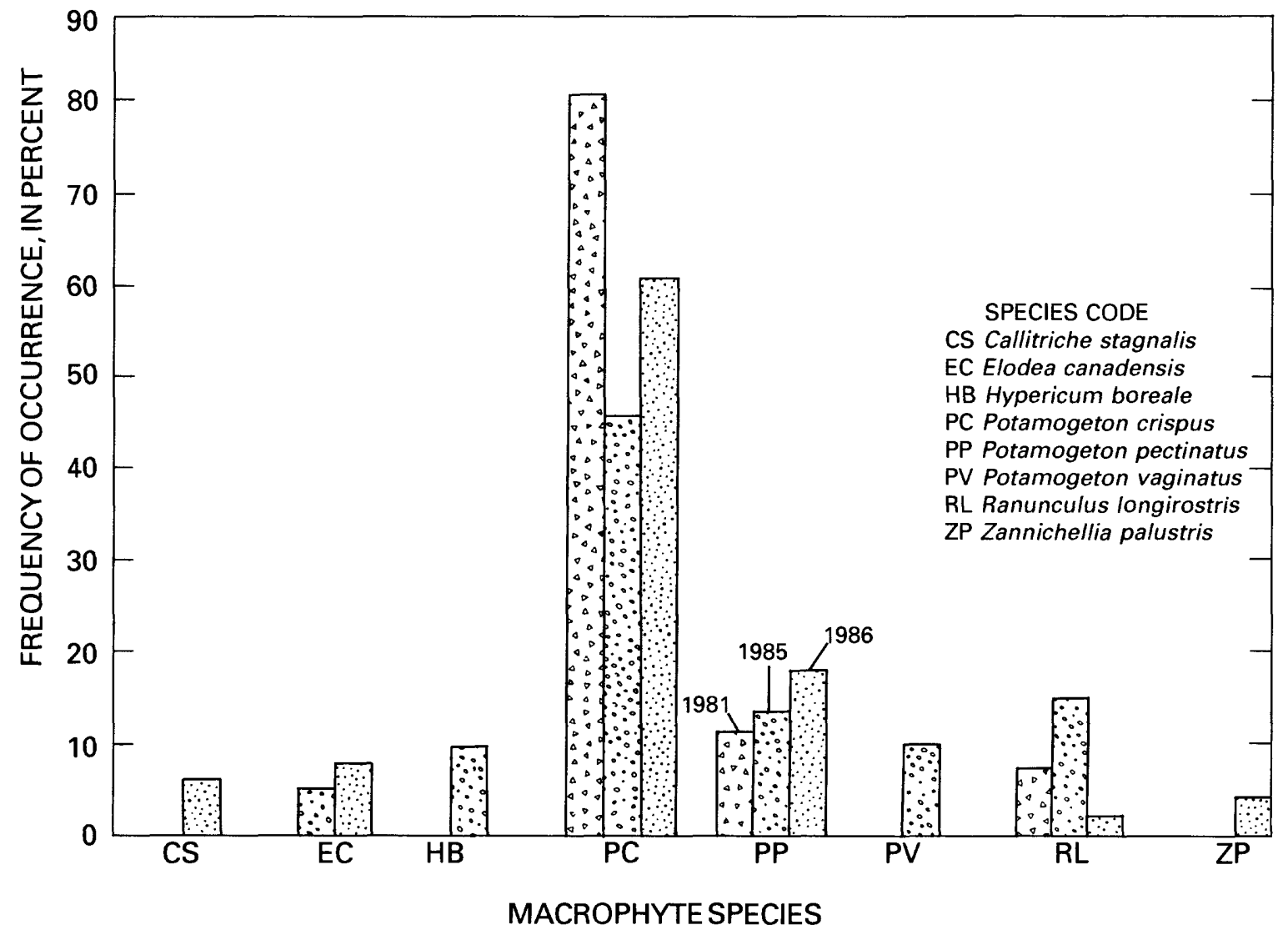

Figure 10. Relative frequency of occurrence of macrophyte species in Black Earth Creek, 1981, 1985, and 1986.

Increasing water temperature is the environmental factor most likely responsible for the shift in dominance from $P$. crispus in reaches 1 and 3 to $P$. pectinatus in reach 7 . Although both Potamogeton species are common dominants in eutrophic, high alkalinity waters, $P$. crispus tends to be dominant either in cooler lakes and streams, or earlier in the season when water temperatures are low (Sahai and Sinha, 1976; Engel, 1985), but $P$. pectinatus is often the only species in warmer eutrophic streams (Madsen, 1986). $P$. crispus tends to become senescent when temperatures exceed $20^{\circ} \mathrm{C}$. $P$. pectinatus, however, is relatively insensitive to maximum temperature in the temperate zone, and tends to be the only species in streams with maximum daily temperatures above $23^{\circ} \mathrm{C}$ (Wong and others, 1978). The longitudinal trend for warming downstream creates the conditions that promote $P$. pectinatus dominance in reach 7 .

The critical temperature to initiate the senescence of $P$. crispus (approximately $20^{\circ} \mathrm{C}$ ) is reached in May at Black Earth Creek at Black Earth and late June at Black Earth Creek at Cross Plains. (See figure 15 in section "Water Temperature".) Therefore, the phenologies of the two reaches are radically different. $\mathrm{P}$. crispus theoretically becomes senescent much earlier in reach 7 than in reaches 1 and 3; this may mean either that it was already senescent when sam- pling began, or that its potential for success in reach 7 is too poor for it to survive or compete against $P$. pectinatus.

$P$. crispus and $P$. pectinatus are nonnative species and are not typical of south-central Wisconsin streams. Species typical in calcareous streams of this region are $E$. canadensis, Nasturtium officinale (watercress) (a semiemergent macrophyte), $R$. longirostris, and Veronica catenata (waterspeedwell). Examination of the submersed macrophyte flora of 10 streams in south-central Wisconsin, and associated literature review showed that $P$. crispus and $P$. pectinatus were present in four streams-Black Earth Creek, Vermont Creek (tributary to Black Earth Creek at Black Earth), Badfish Creek, and Rutland Branch (tributary to Badfish Creek). These two species of Potamogeton are restricted to the most eutrophic streams of the area. Vermont Creek is located 1 mi south of Black Earth whereas Badfish Creek and Rutland Branch are located $25 \mathrm{mi}$ southeast of Black Earth. If the objectives of the priority watershed are met and pollutant loadings are reduced, the native macrophyte species may become more dominant.

\section{Seasonal Succession}

Seasonal succession of species in 1986 in Black Earth Creek is shown in figure 11. $P$. crispus dominated in most 


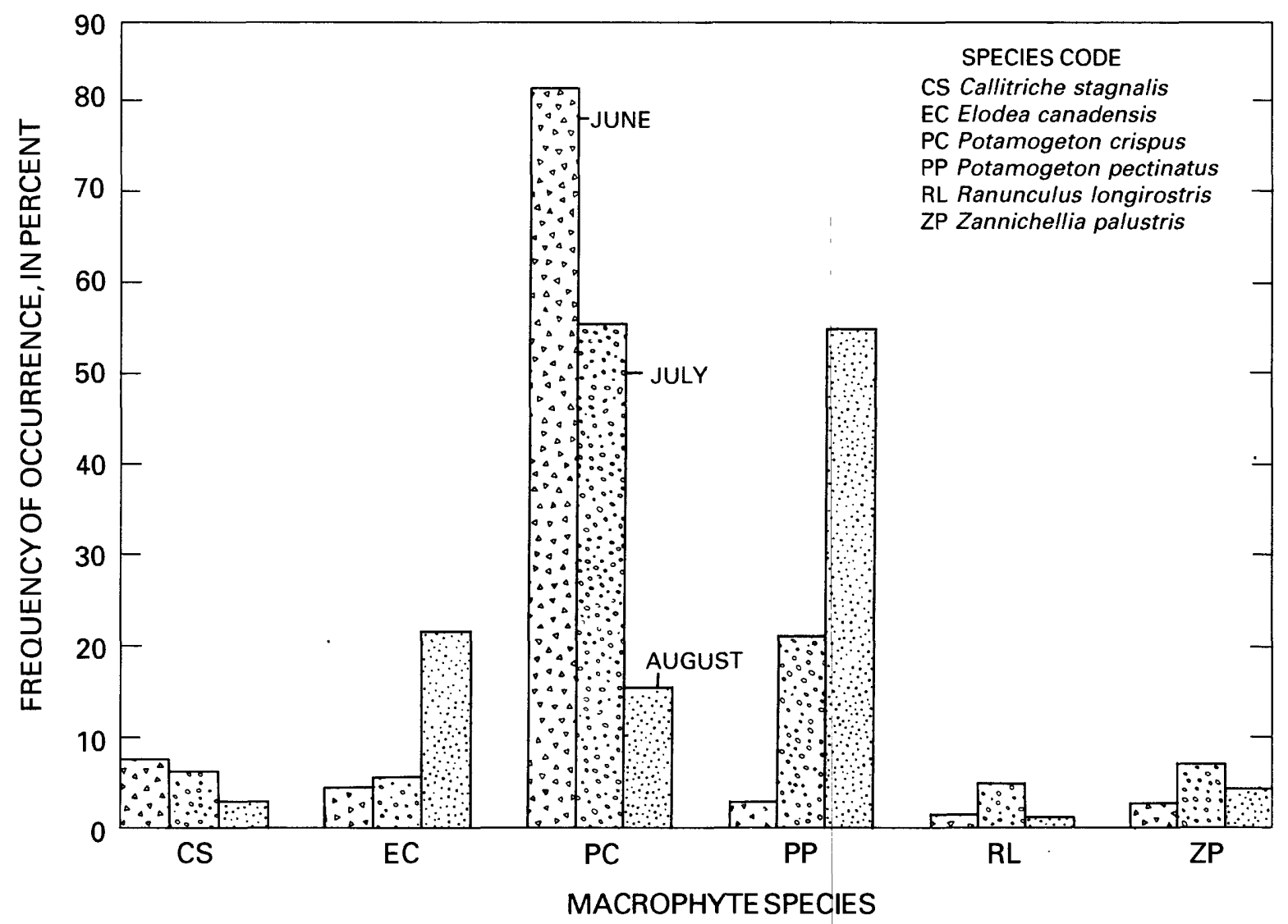

Figure 11. Seasonal succession of species in Black Earth Creek, 1986.

of the stream in June and became senescent by mid-July. The remaining $P$. crispus biomass occurred as dormant stems by August. Other species peaked after $P$. crispus (based on their distribution within the stream); $E$. canadensis or $P$. pectinatus were common late-season dominants. The late season dominants for reaches 1 and 3 were $E$. canadensis or remaining $P$. crispus, but $P$. pectinatus continued to dominate in reach 7 throughout the season. The seasonal growth pattern observed for $P$. pectinatus in Black Earth Creek also was observed at Badfish Creek (Madsen, 1986).

\section{WATER QUALITY}

Stream water quality in Black Earth Creek and its tributaries varies with streamflow. At base flow the water quality is similar to that of ground water; the principal dissolved constituents in the streams are calcium, magnesium, and bicarbonate, which collectively constitute approximately 93 percent of the total dissolved constituents. Sodium, potassium, chloride, and sulfate compose the remaining fraction of dissolved material. Nutrients (nitrogen and phosphorus species) are also found in the stream at base flow, but their concentrations are influenced by factors other than groundwater composition, such as nonpoint sources including storm water and snowmelt runoff from urban and rural land surfaces, livestock operations, and construction activities. The diagram in figure 12 illustrates the chemical compositions of surface and ground water, and their similarities.

Water entering the stream from overland runoff generally increases nitrogen and phosphorus concentrations and decreases (dilutes) concentrations of other dissolved mineral constituents found at base flow. During periods of overland runoff, the concentration of dissolved solids may decrease approximately 50 percent or more, with the exception of potassium, concentrations of which increased slightly (fig. 12).

\section{Influence of Point and Nonpoint Sources}

The water quality of Black Earth Creek is affected by inputs of both point and nonpoint sources. Point sources include discharges from a gravel pit, a landfill site, and a sewage-treatment plant. Nonpoint sources include storm water and snowmelt runoff from urban and rural land surfaces, livestock operations, and construction activities.

Water-quality samples were collected and analyzed from the point sources, gaging stations, and partial-record stations. The water-quality data from the gaging stations and the partial-record stations were used to determine the waterquality characteristics of Black Earth Creek and its tributaries. Samples were collected at all point sources for analysis of total phosphorus. Samples for analysis of dissolved 
phosphorus, dissolved nitrite plus nitrate nitrogen, total Kjeldahl nitrogen, dissolved ammonia nitrogen, total residuenonfilterable, 5-day biochemical oxygen demand (BOD), and chemical oxygen demand (COD) were collected at some of the sites. Samples collected at the gaging stations during two high-flow and three low-flow periods were analyzed for major anions and cations, total phosphorus, dissolved orthophosphate phosphorus, dissolved nitrite plus nitrate nitrogen, dissolved ammonia nitrogen, total Kjeldahl nitrogen, 5-day BOD, and suspended sediment. Samples collected at the partial-record and low-flow stations were analyzed for phosphorus and nitrogen species and suspended-sediment concentrations.

A statistical summary of concentrations of nutrients and suspended sediments at the gaging stations is shown in table 7. The statistical summary shows that Brewery Creek at Cross Plains generally has the highest, or as high as, concentration of all constituents except for nitrite plus nitrate nitrogen. The reasons for the nitrite plus nitrate nitrogen being the exception will be discussed under the section titled "Total Nitrogen".

\section{Point Sources}

\section{Gravel pit}

A gravel pit located approximately $1.8 \mathrm{mi}$ upstream from County Highway $P$ in Cross Plains intermittently discharges water from a pond to Black Earth Creek, affecting the creek's water quantity and quality. The gravel pit pond has a maximum depth of $73 \mathrm{ft}$ and a surface area of 30 acres (Rod Gallagher, gravel pit owner, oral commun., 1987). Water is pumped out of the pond to Black Earth Creek when the water level in the pond becomes too high and hinders the gravel-pit operation (Novitzki, 1973). On December 11, 1985, the measured discharge from the pond was $6.2 \mathrm{ft} 3 / \mathrm{s}$. This discharge to Black Earth Creek caused the streamflow at Cross Plains to increase 4 to $5 \mathrm{ft} 3 / \mathrm{s}$. An increase in discharge also was noted at the Black Earth Creek at Black Earth gaging station. A $2.3 \mathrm{ft} 3 / \mathrm{s}$ increase in flow as a result of water discharged from the pond to Black Earth Creek was noted by Novitzki (1973) in his 1969 study of flow augmentation in Black Earth Creek.

The quality of water discharged from the pond is different than the water quality of the stream at base flow. Waterquality analyses of nutrients during this study period are shown in table 8. Concentrations of these nutrients were lower than those found in the stream at low flow (Holmstrom and others, 1986 and 1987) except nitrite plus nitrate nitrogen was higher. Water temperatures from the effluent from the gravel pit were warmer than stream temperatures.

\section{Landfill site}

A landfill site in the headwaters of Black Earth Creek (fig. 1) poses a potential source of contamination to the stream. Storm runoff that flows through the landfill may carry contaminants into Black Earth Creek.

The landfill (fig. 13a) occupies an area of approximately 19 acres and has a volume of 1.5 million cubic yards (Marie Stewart, Wisconsin Department of Natural Resources, oral commun., 1987). A 16,000- $\mathrm{ft}^{3}$ detention pond (fig. 13a,b) collects overland runoff from the landfill to reduce sediment

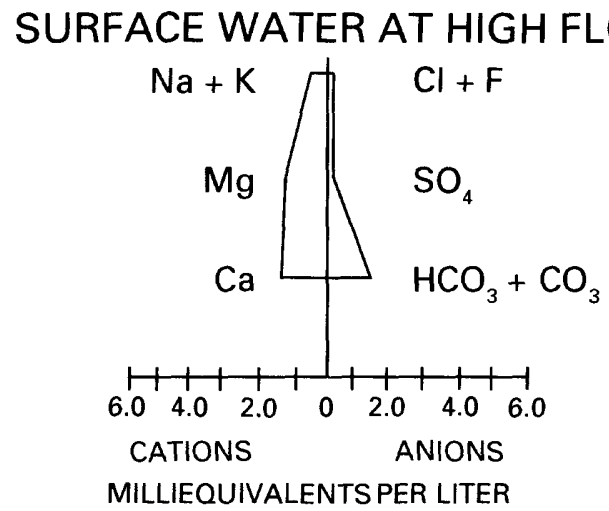

\section{SURFACE WATER AT LOW FLOW}

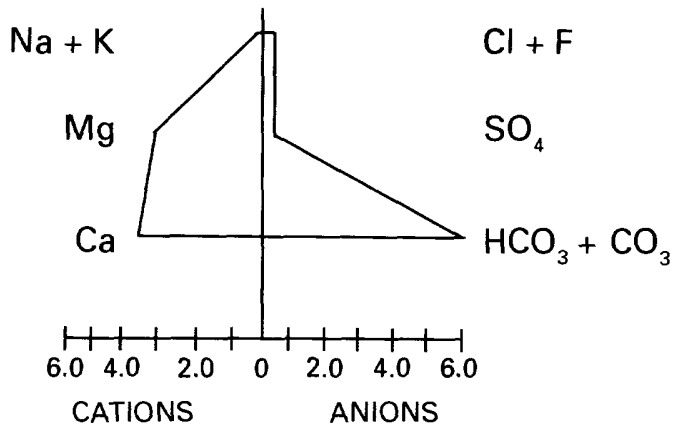

MILLIEQUIVALENTS PER LITER

\section{GROUND WATER}

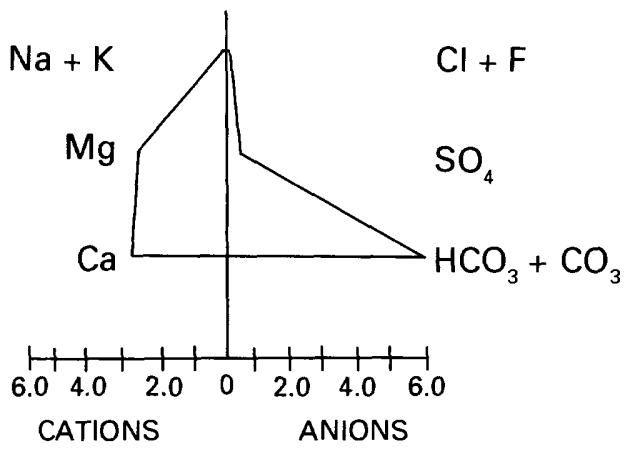

MILLIEQUIVALENTS PER LITER

Figure 12. Relative chemical composition of surface and ground water for Black Earth Creek at Cross Plains. 
input to the stream. Water leaves the pond and drains to a wetland that drains to Black Earth Creek (fig. 13c). When the pond fills, bubbles (probably methane) rising to the surface in the pond indicate the presence of organic material in the sediment.
The landfill site was visited by U.S. Geological Survey personnel on July 25,1985 , following 2.16 and 3.38 in. of rain on July 24 and 25 , respectively. The discharge from the sedimentation pond was estimated to be $0.5 \mathrm{ft}^{3} / \mathrm{s}$ at 1030 hours (fig. 13c) when a water-quality sample was collected. Another

Table 7.-Statistical summary of concentrations of suspended sediment and nutrients at the Black Earth Creek basin streamflow-gaging stations

[units in milligrams per liter unless specified otherwise; $n$ is number of samples; $P_{50}$ is median; $x$ is mean;

$S_{d}$ is standard deviation; Min is minimum; Max is maximum]

\begin{tabular}{|c|c|c|c|c|c|c|c|c|c|}
\hline \multirow{2}{*}{ Constituent } & & \multicolumn{2}{|c|}{$\begin{array}{c}\text { Black Earth Creek } \\
\text { at Cross Plains }\end{array}$} & \multicolumn{2}{|c|}{$\begin{array}{l}\text { Brewery Creek } \\
\text { at Cross Plains }\end{array}$} & \multicolumn{2}{|c|}{$\begin{array}{c}\text { Garfoot Creek } \\
\text { near Cross Plains }\end{array}$} & \multicolumn{2}{|c|}{$\begin{array}{l}\text { Black Earth Creek } \\
\text { at Black Earth }\end{array}$} \\
\hline & & Low flow & High flow & Low flow & High flow & Low flow & High flow & Low flow & High flow \\
\hline \multirow{6}{*}{ Sediment, suspended } & $\mathbf{n}$ & 96 & 100 & 77 & 158 & 66 & 149 & 57 & 124 \\
\hline & $P_{50}$ & 36 & 151 & 77 & 290 & 39 & 150 & 37 & 141 \\
\hline & $\mathbf{x}$ & 40 & 227 & 100 & 453 & 58 & 249 & 50 & 188 \\
\hline & $\mathbf{S}_{\mathrm{d}}$ & 49 & 478 & 80 & 641 & 49 & 247 & 34 & 170 \\
\hline & Min & 9 & 11 & 11 & 24 & 14 & 18 & 11 & 9 \\
\hline & $\operatorname{Max}$ & 295 & 4,770 & 410 & 4,800 & 284 & 1,400 & 156 & 915 \\
\hline \multirow{6}{*}{$\begin{array}{l}\text { Nitrogen, nitrite } \\
\text { plus nitrate, } \\
\text { dissolved }\end{array}$} & $\mathbf{n}$ & 24 & 64 & 18 & 97 & 16 & 69 & 15 & 56 \\
\hline & $P_{50}$ & 2.3 & 1.5 & 2.0 & 1.6 & 2.1 & 2.0 & 2.2 & 1.8 \\
\hline & $\mathbf{x}$ & 2.2 & 1.5 & 2.0 & 1.6 & 2.0 & 2.2 & 2.2 & 1.8 \\
\hline & $\mathrm{S}_{\mathrm{d}}$ & .28 & .43 & .63 & .61 & .17 & .73 & .27 & .41 \\
\hline & Min & 1.6 & .67 & 1.1 & .30 & 1.6 & 1.3 & 1.6 & .96 \\
\hline & $\operatorname{Max}$ & 2.9 & 2.1 & 3.1 & 4.2 & 2.2 & 5.1 & 2.5 & 2.6 \\
\hline \multirow{6}{*}{ Nitrogen, dissolved } & $\mathrm{n}$ & 24 & 59 & 18 & 97 & 16 & 69 & 15 & 56 \\
\hline & $P_{50}$ & .02 & .10 & .10 & .67 & .04 & .44 & .02 & .32 \\
\hline & $\mathbf{x}$ & .03 & .35 & .22 & 1.3 & .06 & .66 & .05 & .76 \\
\hline & $S_{\mathrm{d}}$ & .02 & .45 & .36 & 1.5 & .04 & .62 & .05 & .86 \\
\hline & Min & .02 & .02 & .02 & .02 & .02 & .06 & .02 & .02 \\
\hline & Max & .10 & 1.5 & 1.5 & 7.4 & .18 & 2.2 & .17 & 3.2 \\
\hline \multirow{6}{*}{$\begin{array}{l}\text { Nitrogen, ammonia } \\
\text { plus organic, total }\end{array}$} & $\mathrm{n}$ & 24 & 83 & 19 & 112 & 16 & 87 & 15 & 68 \\
\hline & $P_{50}$ & .40 & 1.6 & .60 & 4.1 & .40 & 3.3 & .40 & 3.3 \\
\hline & $\mathbf{x}$ & .42 & 2.0 & 1.06 & 5.1 & .58 & 3.6 & .51 & 3.6 \\
\hline & $\mathbf{S}_{\mathrm{d}}$ & .25 & 1.4 & 1.15 & 3.9 & .41 & 1.8 & .48 & 2.6 \\
\hline & Min & .20 & .10 & .40 & .50 & .30 & .70 & .20 & .10 \\
\hline & Max & 1.2 & 10 & 5.1 & 23 & 2.0 & 9.4 & 1.70 & 11 \\
\hline \multirow{6}{*}{ Phosphorus, total } & $\mathrm{n}$ & 24 & 83 & 19 & 113 & 16 & 87 & 15 & 68 \\
\hline & $P_{50}$ & .05 & .44 & .14 & 1.4 & .08 & 1.1 & .10 & 1.0 \\
\hline & $\mathbf{x}$ & .07 & .54 & .25 & 1.6 & .11 & 1.1 & .13 & .97 \\
\hline & $\mathrm{S}_{\mathrm{d}}$ & .05 & .38 & .24 & 1.2 & .12 & .51 & .11 & .56 \\
\hline & Min & .02 & .01 & .08 & .19 & .06 & .05 & .06 & .01 \\
\hline & $\operatorname{Max}$ & .22 & 1.9 & .97 & 9.0 & .54 & 2.7 & .40 & 2.3 \\
\hline \multirow{6}{*}{$\begin{array}{l}\text { Phorphorus, ortho, } \\
\text { dissolved }\end{array}$} & $\mathrm{n}$ & 16 & 6 & 15 & 5 & 14 & 5 & 13 & 7 \\
\hline & $P_{50}$ & .02 & .28 & .04 & .51 & .04 & .79 & .05 & .45 \\
\hline & $\mathbf{x}$ & .02 & .27 & .06 & .72 & .04 & .61 & .06 & .44 \\
\hline & $\mathbf{S}_{\mathrm{d}}$ & .006 & .14 & .04 & .49 & .01 & .35 & .02 & .32 \\
\hline & Min & .01 & .10 & .03 & .42 & .03 & .09 & .04 & .08 \\
\hline & $\operatorname{Max}$ & .03 & .44 & .14 & 1.6 & .06 & .92 & .08 & .97 \\
\hline
\end{tabular}


water-quality sample was collected by DNR personnel from the water in the sedimentation pond on April 28, 1986. The results of these two analyses are shown in table 8 . The pond water on April 28, 1986, had a dissolved ammonia nitrogen concentration $\left(\mathrm{NH}^{3}-\mathrm{N}\right)$ of $60 \mathrm{mg} / \mathrm{L}$ and a $\mathrm{pH}$ of 7.9 ; with an assumed water temperature of $0{ }^{\circ} \mathrm{C}$, the pond water would contain an un-ionized ammonia $\left(\mathrm{NH}^{3}-\mathrm{N}\right)$ concentration of $0.40 \mathrm{mg} / \mathrm{L}$ at equilibrium. This would exceed the criteria of $0.016 \mathrm{mg} / \mathrm{L}$ of ammonia specified by the DNR (D. H. Schuettpelz and T. N. Harpt, Wisconsin Department of Natural Resources, written commun., 1980) for trout. The $0.016-\mathrm{mg} / \mathrm{L}$ criterion is for in-stream concentration. The water temperature of $0{ }^{\circ} \mathrm{C}$ was assumed to provide the most conservative estimate of toxicity. The effluent from the settling pond drains into a small wetland and then to a tributary to Black Earth Creek.

Biochemical oxygen demand concentrations of 420 and $980 \mathrm{mg} / \mathrm{L}$ were measured in effluent from the pond and water in the pond, respectively. There are no State standards for BOD and COD to compare to the quality of water from the sedimentation pond, but the BOD concentration exceeded the maximum of $30 \mathrm{mg} / \mathrm{L}$ allowed by the DNR for discharge from the sewage-treatment plant at Cross Plains. For comparison untreated sewage from the sewage-treatment plant in Cross
Plains collected on March 19, 1985 (table 8), had a BOD concentration of $220 \mathrm{mg} / \mathrm{L}$.

\section{Sewage-treatment plant}

Effluent from the sewage-treatment plant at the western side of Cross Plains has created dissolved-oxygen problems for the trout fishery in the past (Brynildson and Mason, 1975). However, no fishkills have been observed since secondary treatment facilities were put into operation at the sewagetreatment plant in 1968.

Inadequately treated sewage was noted being discharged from the sewage-treatment plant on a number of occasions in March 1985 (Jim Baumann, Wisconsin Department of Natural Resources, oral commun., 1988). This situation was corrected shortly afterward and the plant appeared to have no malfunctions after that. Analyses of the effluent of the untreated and treated sewage are shown in table 8.

Total phosphorus concentrations of treated effluent ranged from 3.9 to $8.4 \mathrm{mg} / \mathrm{L}$; the mean was $6.3 \mathrm{mg} / \mathrm{L}$ and the median was $6.4 \mathrm{mg} / \mathrm{L}$ for a 4-month period April through August 1985. Assuming an average concentration of $6.3 \mathrm{mg} / \mathrm{L}$ and an average discharge of treated effluent of $220,000 \mathrm{gal} / \mathrm{d}$ (gallons per day), the sewage-treatment plant would contribute $4,430 \mathrm{lb} / \mathrm{yr}$ (pounds per year) of total phosphorus to the

\section{Table 8.-Black Earth Creek point-source water-quality analyses}

[units in milligrams per liter unless specified otherwise; ${ }^{\circ} \mathrm{C}=$ degrees Celsius; $\mu \mathrm{S} / \mathrm{cm}=$ microsiemens per centimeter at $25^{\circ}$ Celsius; $<=$ less than; $-=$ no data available]

\begin{tabular}{|c|c|c|c|c|c|c|c|c|c|c|c|c|}
\hline Date & Time & $\begin{array}{l}\text { Total } \\
\text { phos- } \\
\text { phorus } \\
\text { as } \mathbf{P}\end{array}$ & $\begin{array}{l}\text { Dissolved } \\
\text { orth- } \\
\text { phosphorus } \\
\text { as P }\end{array}$ & $\begin{array}{l}\text { Nitrite plus } \\
\text { nitrate nitro- } \\
\text { gen dissolved } \\
\text { as } N\end{array}$ & $\begin{array}{c}\text { Total } \\
\text { Kjeldahl } \\
\text { nitrogen } \\
\text { as } \mathbf{N}\end{array}$ & $\begin{array}{l}\text { Ammonia } \\
\text { nitrogen } \\
\text { dissolved } \\
\text { as } \mathbf{N}\end{array}$ & $\begin{array}{l}\text { Residue } \\
\text { total non- } \\
\text { filterable }\end{array}$ & $\begin{array}{l}\text { BOD } \\
\text { 5-day }\end{array}$ & COD & $\begin{array}{c}\text { Con- } \\
\text { duct- } \\
\text { ance } \\
(\mu \mathrm{S} / \mathrm{cn})\end{array}$ & pH & $\begin{array}{c}\text { Water } \\
\text { teniper- } \\
\text { ature } \\
\left({ }^{\circ} \mathrm{C}\right)\end{array}$ \\
\hline \multicolumn{13}{|c|}{ Untreated sewage-treatment plant effluent } \\
\hline Mar. 19, 1985 & 0950 & 19 & - & 6.8 & 42 & 0.7 & 660 & 220 & - & - & 8.1 & - \\
\hline \multicolumn{13}{|c|}{ Treated effluent } \\
\hline Apr. 9, 1985 & 0830 & 3.9 & 2.9 & & & & & & & & & \\
\hline Apr. 23, 1985 & 0845 & 5.6 & 5.3 & & & & & & & & & \\
\hline June 19,1985 & - & 8.4 & 7.0 & 19.0 & & $<.1$ & & & & & & \\
\hline June 25,1985 & - & 7.6 & 5.8 & & & & & & & & & \\
\hline July 17,1985 & - & 7.2 & 6.8 & & & & & & & & & \\
\hline July 24,1985 & - & 6.4 & 6.0 & & & & & & & & & \\
\hline Aug. 7, 1985 & - & 5.3 & 4.7 & & & & & & & & & \\
\hline \multicolumn{13}{|c|}{ Gravel-pit discharge } \\
\hline June 13, 1985 & 1300 & $<0.02$ & .004 & 3.3 & $<.2$ & $<.02$ & & & & & & 18 \\
\hline Dec. 11, 1985 & 0910 & .02 & .006 & 3.1 & $<.2$ & $<.02$ & & & & & & \\
\hline Feb. 19, 1986 & 0955 & .06 & .005 & 3.4 & 6 & $<.02$ & & & & & & \\
\hline \multicolumn{13}{|c|}{ Landfill pond } \\
\hline July 25,1985 & 1030 & 8.8 & - & .65 & - & - & 384 & 420 & 1,300 & 1,500 & 7.1 & 24 \\
\hline Apr. 28, 1986 & 1430 & .76 & - & - & - & 60 & - & 980 & 1,300 & 3,300 & 7.9 & - \\
\hline \multicolumn{13}{|c|}{ Farm fields } \\
\hline Mar. 9, 1985 & 1715 & 1.15 & .82 & .8 & 4.6 & 2.3 & & & & & & \\
\hline Apr. 9, 1985 & 0815 & 1.3 & - & .1 & 4.6 & 1.5 & & & & & & \\
\hline
\end{tabular}




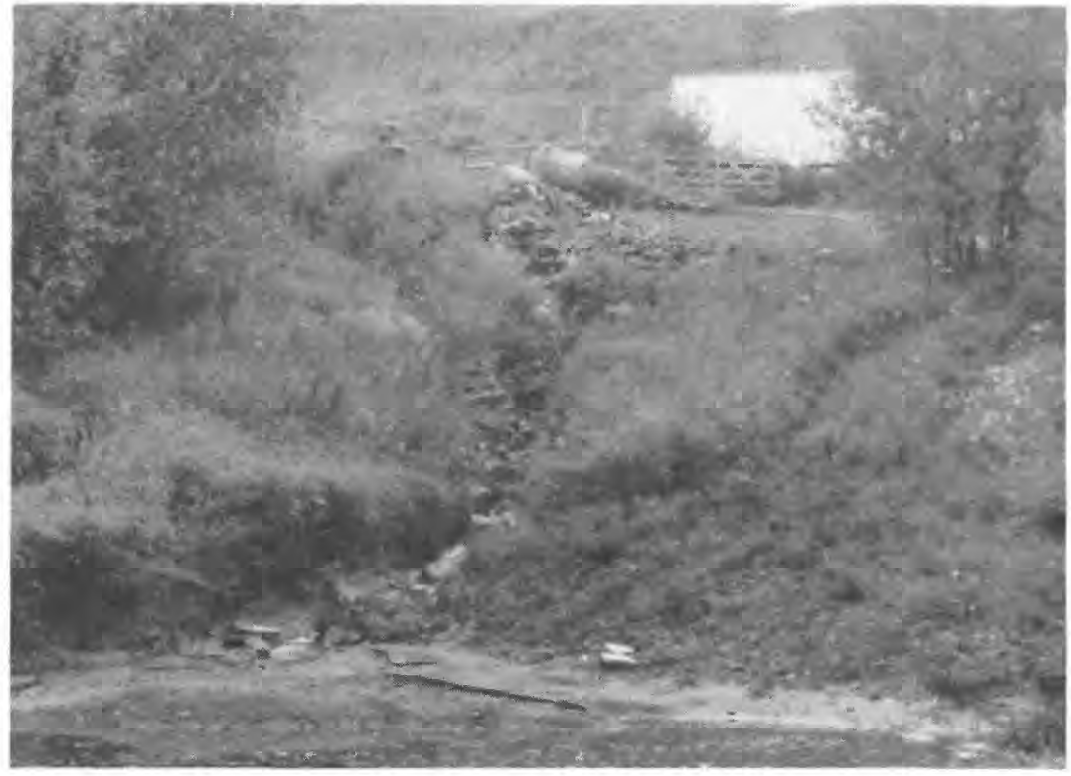

A. View of drainage ditch from landfill to sedimentation pond.

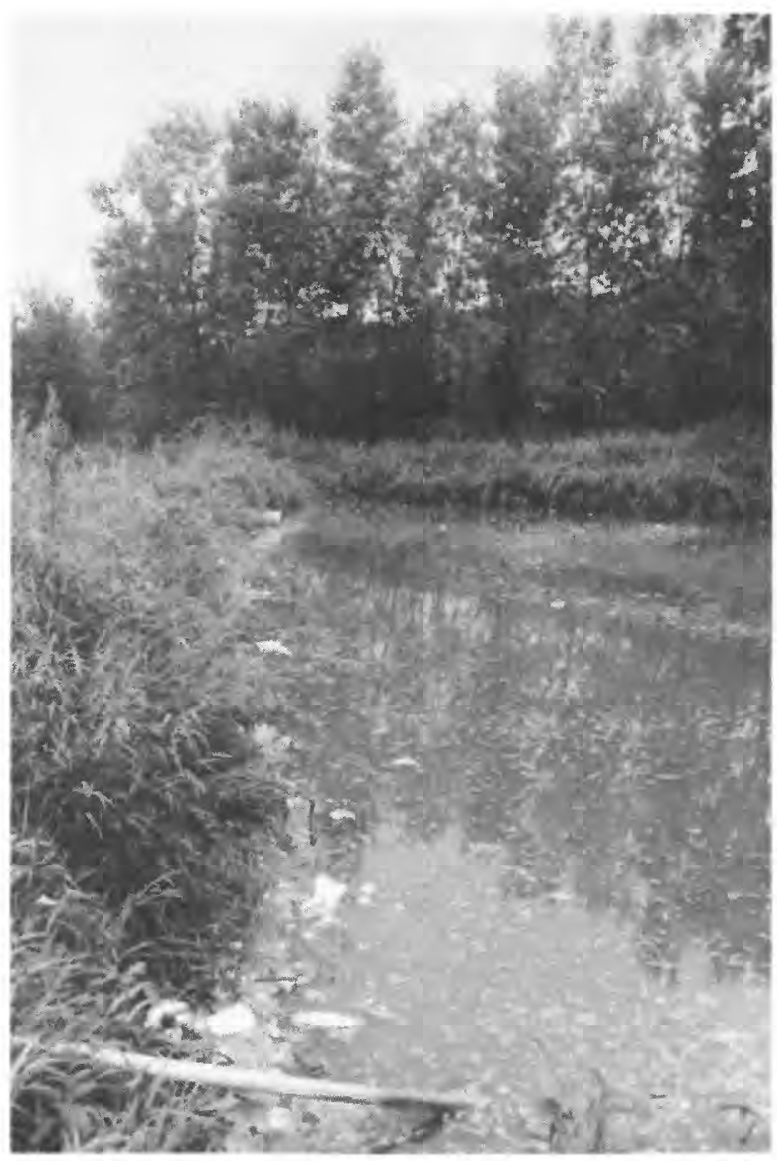

B. View of sedimentation pond culvert, outlet pipe, and sedimentation pond berm.

C. View of sedimentation pond culvert; the estimated discharge was 0.5 cubic feet per second.

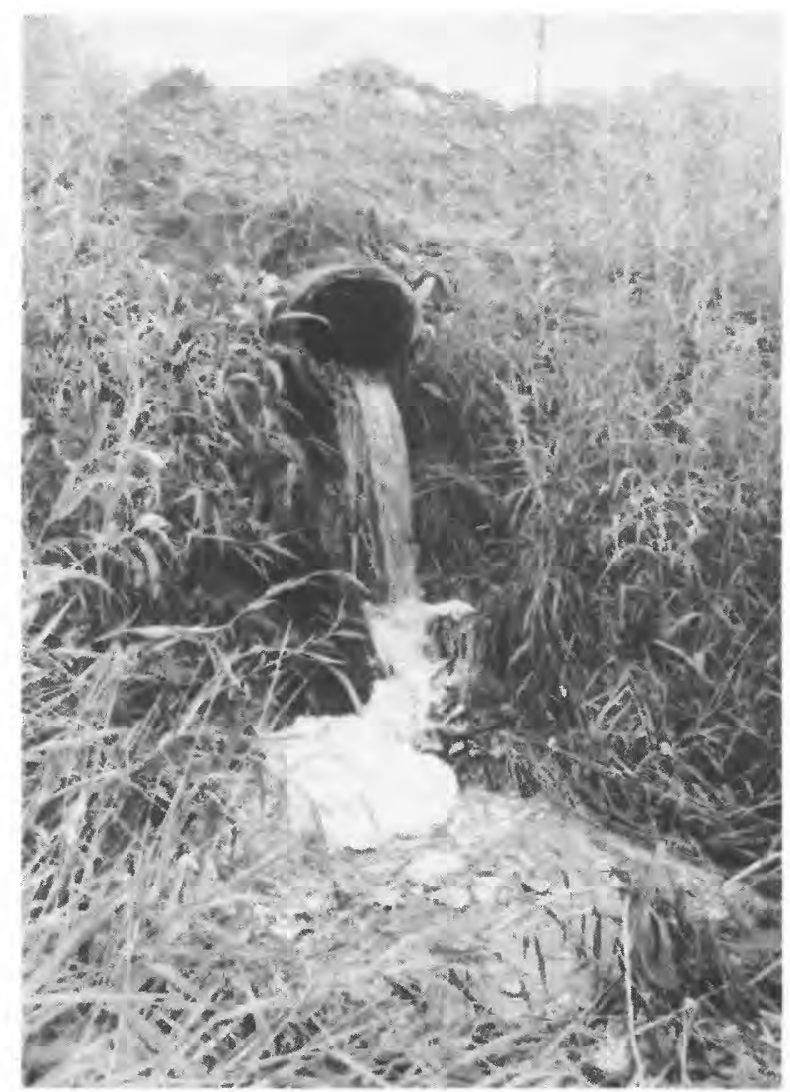

Figure 13. Landfill site, July 2, 1985. 
stream. This is fairly comparable to the loads determined at the three upstream gaging stations: Black Earth Creek at Cross Plains, Garfoot Creek at Cross Plains, and Brewery Creek at Cross Plains (table 9).

\section{Farm fields}

A berm has been installed in the headwaters of the Black Earth Creek basin (fig. 1) where flat channel slopes inhibit drainage. When overland runoff collects upstream from this berm an automatic pump is activated to lower the water level to allow for farm field drainage. The berm prevents water from traveling up the channel. Higher than normal flows with high nutrient concentrations (table 8) are sustained well after the stream has normally receded after storm runoff. Although suspended-sediment samples were not collected, it is likely the suspended-sediment concentrations in water pumped from the pond would be low because of settling and deposition in the pond upstream. Low suspended-sediment concentrations may benefit the stream; sedimentation is detrimental because it covers trout redds, fills pools that are necessary for trout habitat, and increases the substrate for macrophyte attachment.

\section{Nonpoint Sources}

Suspended sediment and nutrients can adversely affect the stream ecosystem. Suspended-sediment particles (in

Table 9.-Suspended-sediment and nutrient loads and yields for the Black Earth Creek basin streamflow-gaging stations and partial-record stations, 1985 and 1986 water years

[tons $/ \mathrm{mi}^{2}=$ tons per square mile; $\mathrm{lb}=$ pounds; $\mathrm{lb} / \mathrm{mi}^{2}=$ pounds per square mile]

\begin{tabular}{|c|c|c|c|c|c|c|c|}
\hline \multirow[b]{2}{*}{ Station name } & \multirow{2}{*}{$\begin{array}{c}\text { Drainage } \\
\text { area }\end{array}$} & \multicolumn{2}{|c|}{ Suspended sediment } & \multicolumn{2}{|c|}{ Total phosphorus } & \multicolumn{2}{|c|}{ Total nitrogen } \\
\hline & & $\begin{array}{c}\text { Annual load } \\
\text { (tons) }\end{array}$ & $\begin{array}{l}\text { Annual yield } \\
\text { (tons } / \mathbf{m i}^{2} \text { ) }\end{array}$ & $\begin{array}{l}\text { Annual load } \\
\text { (lb) }\end{array}$ & $\begin{array}{l}\text { Annual yield } \\
\left(\mathbf{l b} / \mathbf{m i}^{\mathbf{2}}\right)\end{array}$ & $\begin{array}{l}\text { Annual load } \\
\text { (lb) }\end{array}$ & $\begin{array}{c}\text { Annual yield } \\
\left(\mathbf{l b} / \mathbf{m i}^{2}\right)\end{array}$ \\
\hline \multicolumn{8}{|c|}{1985 water year } \\
\hline Continuous gaging sta & ons & & & & & & \\
\hline $\begin{array}{l}\text { Black Earth Creek at } \\
\text { Cross Plains }\end{array}$ & 14.6 & 1,020 & 69.5 & 4,550 & 312 & 89,200 & 6,110 \\
\hline Brewery Creek & 17.70 & 894 & 116 & 4,840 & 628 & 25,200 & 3,280 \\
\hline Garfoot Creek & 5.39 & 462 & 85.7 & 3,060 & 569 & 37,300 & 6,920 \\
\hline $\begin{array}{l}\text { Black Earth Creek at } \\
\text { Black Earth }\end{array}$ & 142.8 & 4,210 & 98.4 & 23,400 & 546 & 286,000 & 6,670 \\
\hline \multicolumn{8}{|l|}{ Partial-record stations } \\
\hline $\begin{array}{l}\text { Black Earth Creek } \\
\text { partial-record site } 1\end{array}$ & 3.32 & 120 & 36 & 730 & 220 & 31,000 & 9,500 \\
\hline $\begin{array}{l}\text { Brewery Creek par- } \\
\text { tial-record site } 3\end{array}$ & 15.04 & 790 & 160 & 2,800 & 550 & 16,000 & 3,200 \\
\hline $\begin{array}{l}\text { Black Earth Creek } \\
\text { tributary partial- } \\
\text { record site } 4\end{array}$ & 5.78 & 1,200 & 200 & 2,700 & 460 & 23,000 & 4,000 \\
\hline $\begin{array}{l}\text { Black Earth Creek } \\
\text { tributary partial- } \\
\text { record site } 5\end{array}$ & 2.89 & 120 & 43 & 930 & 320 & 5,100 & 1,800 \\
\hline \multicolumn{8}{|c|}{1986 water year (October 1 to June 30 only) } \\
\hline \multicolumn{8}{|c|}{ Continuous gaging stations } \\
\hline $\begin{array}{l}\text { Black Earth Creek } \\
\text { at Cross Plains }\end{array}$ & 14.6 & 454 & 31.1 & 1,540 & 106 & 70,400 & 4,820 \\
\hline Brewery Creek & 17.70 & 279 & 36.2 & 1,590 & 206 & 5,000 & 1,940 \\
\hline Garfoot Creek & 5.39 & 441 & 81.8 & 2,450 & 454 & 30,700 & 5,690 \\
\hline $\begin{array}{l}\text { Black Earth Creek at } \\
\text { Black Earth }\end{array}$ & 142.8 & 3,230 & 75.4 & 13,000 & 303 & 227,000 & 5,300 \\
\hline
\end{tabular}

${ }^{1}$ Drainage of contributing area only. 
the silt- and clay-size range) deposited in the streambed during trout reproduction periods can inhibit the survival rate of fingerlings (Michigan State University, 1985). Suspended sediment transported by Black Earth Creek at Black Earth is about two-thirds clay and one-third silt (1954 to 1959 data; Collier, 1963). Macrophyte densities depend in part on sediment deposited on the streambed and its nutrient composition. These nutrients come from those deposited from the water column transported primarily during storms.

In Black Earth Creek sedimentation poses a threat to the trout fishery (University of Wisconsin-Extension, 1988). In many reaches of Black Earth Creek, 5 to 6 in. of sediment cover the gravel bottom. Measurements in one pool near Black Earth showed that it was filled with $5 \mathrm{ft}$ of sediment. Gravel bottoms are important for trout spawning and pools provide cover for mature fish (University of WisconsinExtension, 1988).

Sedimentation during winter is especially damaging to trout. Smothering of fish eggs and larval fish by sediment particles that are transported during winter storms can cause mortality and low reproduction success (Brynildson and Brynildson, 1984). In the winter of 1982-83, heavy sedimentation occurred in Brewery and Black Earth Creeks from urban development in the Brewery Creek basin in Cross Plains (Seely, 1983). The heavy sedimentation from Brewery Creek covered prime trout spawning habitat and caused trout redds to be destroyed in Black Earth Creek (Scott Stewart, Wisconsin Department of Natural Resources, oral commun., 1988).

The characteristics of suspended sediment and nutrients from nonpoint sources were evaluated by calculating the loads at each gaging station for WY 1985 and October 1 to June 30 for WY 1986, and by estimating the loads at each partial-record station for WY 1985. Loads and yields at the gaging stations and partial-record stations are shown in table 9 .

\section{Load determinations}

The loads of suspended sediment and nutrients at the gaging stations and partial-record stations were determined by two methods. The loads at the gaging stations (table 9) were computed by streamflow and concentration-integration techniques described by Porterfield (1972). These loads and the discrete analyses are published in "Water Resources Data for Wisconsin, 1985" (Holmstrom and others, 1986) and "Water Resources Data for Wisconsin, 1986" (Holmstrom and others, 1987).

Loads at the partial-record stations for WY 1985 were estimated by the following technique. Instantaneous loads at the partial-record stations were calculated for discrete samples and discharges. Loads at the partial-record stations were plotted against the gaging station instantaneous loads. A bestfit regression line was drawn through these data points and the equation of the line was determined. This equation was then applied to that constituent's daily load at the gaging sta- tion to estimate the load at the partial-record site. An example of this technique is shown in figure 14. The equations used to estimate the loads of the partial-record stations are as follows:

Partial-record site 1-Black Earth Creek near Middleton (05406450)

$$
\begin{aligned}
& \mathrm{TP}-0.35\left(\mathrm{TP}_{\mathrm{BEC}}\right)^{0.749} \\
& \mathrm{TN}-1.1\left(\mathrm{TN}_{\mathrm{BEC}}\right)^{0.796} \\
& \text { SS-0.133(SS } \text { BEC }^{0.915}
\end{aligned}
$$

where $\mathrm{BEC}=$ Black Earth Creek at Cross Plains (05406460)

Partial-record site 3-Brewery Creek near Cross Plains (05406468)

$$
\begin{aligned}
& \mathrm{TP}-0.84\left(\mathrm{TP}_{\mathrm{BRC}}\right)^{0.927} \\
& \mathrm{TN}-1.2\left(\mathrm{TN}_{\mathrm{BRC}}\right)^{0.883} \\
& \mathrm{SS}-1.13\left(\mathrm{SS}_{\mathrm{BRC}}\right)^{0.938}
\end{aligned}
$$

where BRC $=$ Brewery Creek at Cross Plains (05406470)

Partial-record site 4-Unnamed tributary to Black Earth Creek (05406488)

$$
\begin{aligned}
& \mathrm{TP}-0.40\left(\mathrm{TP}_{\mathrm{GAR}}\right)^{1.18} \\
& \mathrm{TN}-0.28\left(\mathrm{TN}_{\mathrm{GAR}}\right)^{1.15} \\
& \mathrm{SS}-0.92\left(\mathrm{SS}_{\mathrm{GAR}}\right)^{1.43}
\end{aligned}
$$

where GAR $=$ Garfoot Creek at Cross Plains (05406491)

Partial-record site 5-Unnamed tributary to Black Earth Creek (054064975)

$$
\begin{aligned}
& \mathrm{TP}-0.08\left(\mathrm{TP}_{\mathrm{GAR}}\right)^{1.29} \\
& \mathrm{TN}-0.014\left(\mathrm{TN}_{\mathrm{GAR}}\right)^{1.416} \\
& \mathrm{SS}-0.10\left(\mathrm{SS}_{\mathrm{GAR}}\right)^{1.429}
\end{aligned}
$$

where GAR = Garfoot Creek at Cross Plains (05406491)

where:

$$
\begin{aligned}
& \mathrm{TP}=\text { total annual phosphorus load, in pounds, } \\
& \mathrm{TN} \text { = total annual nitrogen load, in pounds, and } \\
& \mathrm{SS}=\text { annual suspended-sediment load, in tons. }
\end{aligned}
$$

To test the accuracy of the method, it was used to estimate the total phosphorus, total nitrogen, and suspendedsediment loads at Black Earth Creek at Black Earth and Black Earth Creek at Cross Plains by using the loads at Garfoot Creek. Samples were chosen from the Black Earth Creek 
gaging stations as near to the times as those samples that were collected at the partial-record station 05406488 (partial-record site 4). The results of these estimates compared to values calculated by the integration method are shown below:

\begin{tabular}{lccc}
\hline & $\begin{array}{c}\text { Total } \\
\text { phosphorus } \\
\text { load } \\
\text { (in pounds) }\end{array}$ & $\begin{array}{c}\text { Total } \\
\text { nitrogen } \\
\text { load } \\
\text { (in pounds) }\end{array}$ & $\begin{array}{c}\text { Suspended } \\
\text { sediment } \\
\text { load } \\
\text { (in tons) }\end{array}$ \\
\hline Estimated & Black Earth Creek at Cross Plains & (05406460) \\
Computed & 3,340 & 86,900 & 986 \\
$\begin{array}{l}\text { Percent } \\
\text { difference }\end{array}$ & 4,550 & 89,200 & 1,020 \\
& -27 & -3 & 3 \\
Estimated & 23,300 & 320,000 & 6,990 \\
Computed & 23,400 & 286,000 & 4,210 \\
Percent & & & 66 \\
\hline difference & 0 & 12 & \\
\hline
\end{tabular}

The above comparison shows an acceptable error and the method was used to estimate loads at the partial-record station.

\section{Suspended sediment}

Suspended-sediment data are available for the Black Earth Creek at Black Earth gaging station from WY 1954-65 and 1985-86 (table 10). Suspended-sediment records are not available for the WY 1966-84 period. The average suspendedsediment yield for this basin, for the 12 years of record (WY 1955-65, WY 1985), is 76.2 tons $/ \mathrm{mi}^{2}$. Suspended-sediment yields ranged from 7.92 tons $/ \mathrm{mi}^{2}$ in WY 1964 to 172 tons $/ \mathrm{mi}^{2}$ in WY 1960. The annual sediment yield in 1954 was 172 tons $/ \mathrm{mi}^{2}$ when data were available for only 8 months. During this study, the suspended-sediment yield during WY 1985 was 29 percent greater than the 12-year average. The suspendedsediment yield during WY 1986 probably was greater than average because only 9 months of data (October-June) were already near the 12-year average.

Suspended-sediment loads are a product of stream runoff and concentration. Runoff from the Brewery Creek basin is extremely low and averaged 10.4 in. less than the other gaged basins (table 4). Despite the low runoff at the Brewery Creek basin, suspended-sediment concentrations are highest during low and high flows (table 7).

Suspended-sediment yields are affected by basin slopes (Chow, 1964). Generally the steeper the slope, the greater the sediment yield. Channel slopes are steepest in Garfoot Creek and are not as steep in Black Earth Creek (at Black

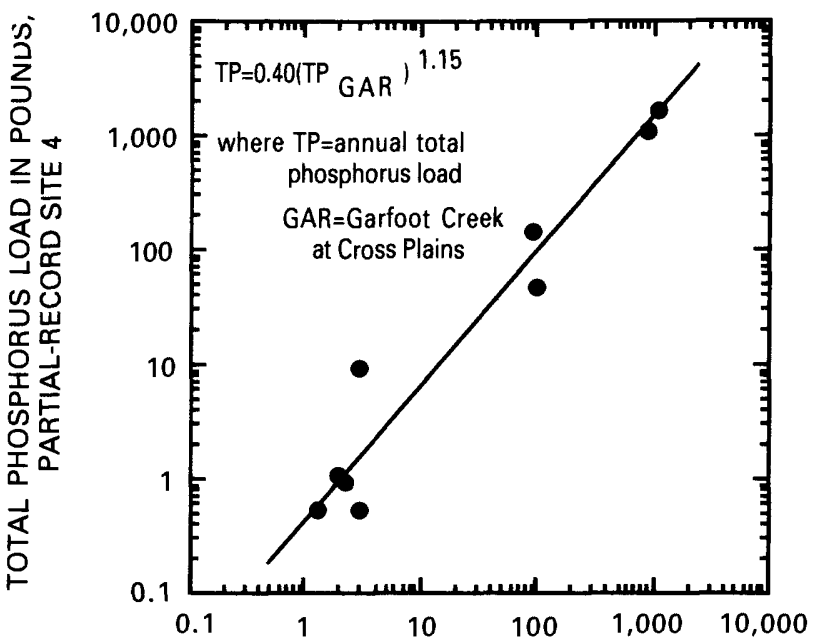

TOTAL PHOSPHORUS LOAD, IN POUNDS, GARFOOT

A. CREEK NEAR CROSS PLAINS GAGING STATION

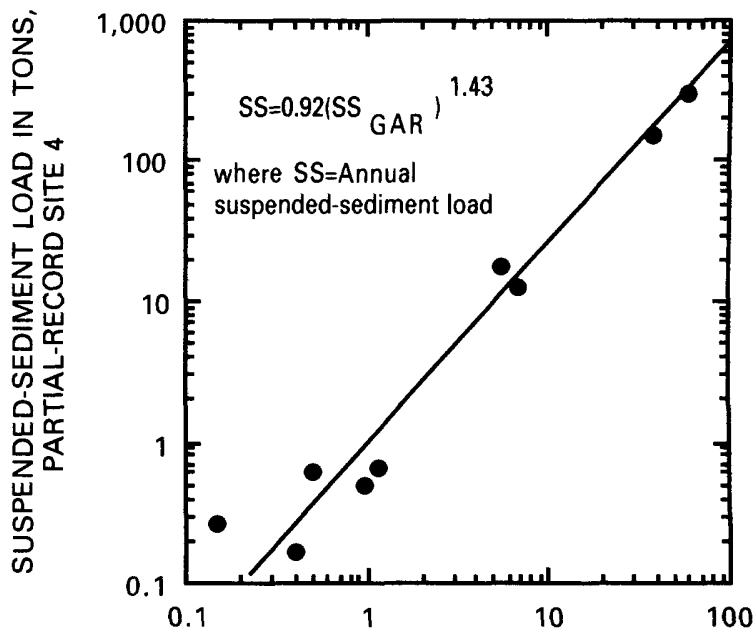

SUSPENDED-SEDIMENT LOAD, IN TONS, GARFOOT

B. CREEK NEAR CROSS PLAINS GAGING STATION

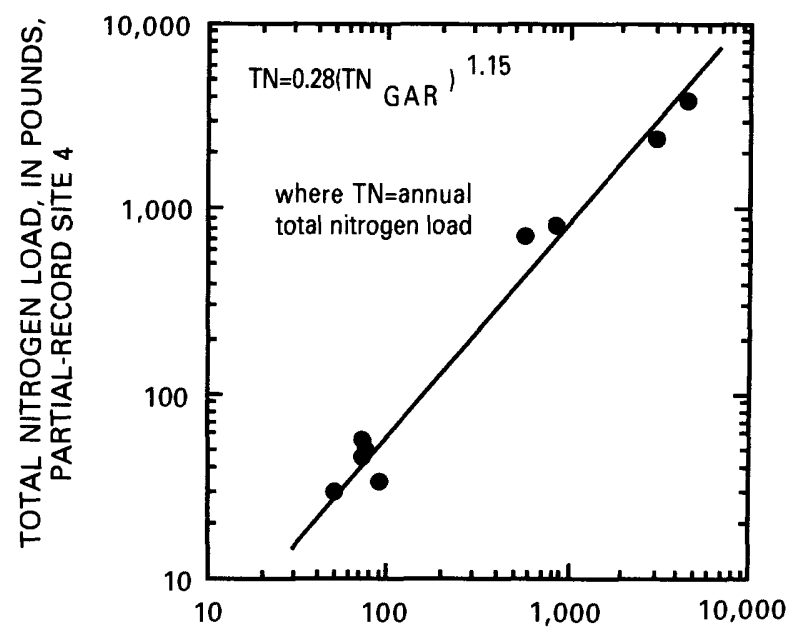

TOTAL NITROGEN LOAD, IN POUNDS, GARFOOT C. CREEK NEAR CROSS PLAINS GAGING STATION

Figure 14. Comparison of total phosphorus, suspendedsediment, and total nitrogen loads for partial-record site 4 with those at Garfoot Creek near Cross Plains streamflow-gaging station. 
Earth) (fig. 2). Suspended-sediment yields at the gaging stations (table 9) ranged from 69.5 tons $/ \mathrm{mi}^{2}$ in the Black Earth Creek at Cross Plains basin to 116 tons $/ \mathrm{mi}^{2}$ in the Brewery Creek basin during WY 1985. Suspended-sediment yields during WY 1986 (only data from October 1 to June 30) ranged from 31.1 tons $/ \mathrm{mi}^{2}$ in the Black Earth Creek at Cross Plains basin to 81.8 tons $/ \mathrm{mi}^{2}$ in the Garfoot Creek basin.

The reason for the maximum sediment yield for the two water years to be in different basins can possibly be explained by the dry-dam detention ponds in the Brewery Creek basin and runoff peaks. There are five detention ponds in the headwaters of the Brewery Creek basin, where channel slopes are steepest. These ponds collectively drain $1.32 \mathrm{mi}^{2}$, which comprises 17 percent of the contributing area of the basin. These ponds appear to be effective in controlling sediment runoff from small storms (storms with a recurrence interval of less than 2 years), but these small detention ponds probably do not have the capacity to hold the runoff from the larger events (greater than a 2-year recurrence interval such as that on July 25), and the water and sediments pass through these detention ponds.

In WY 1985, if the July 25 storm sediment load (Black Earth Creek at Cross Plains, 60 tons; Brewery Creek, 493 tons; Garfoot Creek, 62 tons; Black Earth Creek at Black Earth, 466 tons) is factored out of all annual loads, the yields for each basin would be as follows: Black Earth Creek at Cross Plains, 66 tons $/ \mathrm{mi}^{2}$; Brewery Creek, 52 tons $/ \mathrm{mi}^{2}$; Garfoot Creek, 74 tons $/ \mathrm{mi}^{2}$; and Black Earth Creek at Black Earth, $87 \mathrm{tons} / \mathrm{mi}^{2}$. Therefore, it appears that of the three upstream basins, the Garfoot Creek basin has the highest sediment yield during low to moderate runoff events; the detention ponds in the Brewery Creek basin become less effective in controlling suspended-sediment runoff during periods of large runoff peaks and the yields in this basin are highest during high flows. The downstream gaging station Black Earth Creek at Black Earth is affected by the high sediment yields from the upstream tributary streams-Garfoot Creek and partial-record stations 4 and 5 (and Brewery Creek during large storms greater than a 2-year storm frequency)-and yields increase from those upstream at Black Earth Creek at Cross Plains.

Another indicator of soil loss from a basin is use of the Universal Soil Loss Equation (USLE) (Wischmeier and Smith, 1978). The average soil losses from the subbasins of Black Earth Creek were estimated by the Institute for Environmental Studies group by delineating a quarter-mile corridor around each stream (Institute for Environmental Studies, 1986). They estimated soil losses, in tons per square mile per year, as follows: Black Earth Creek at Cross Plains, 928; Brewery Creek, 1,240; Garfoot Creek, 1,240; and Black Earth Creek at Black Earth, 960. The basin area of the Black Earth Creek at Black Earth did not include the areas upstream from Black Earth Creek at Cross Plains, Brewery Creek at Cross Plains, and Garfoot Creek near Cross Plains. The USLE does not indicate net erosion; most of the sediment eroded is redeposited on the land and only a small percentage reaches the stream to be transported. However, it does provide a valuable comparison with the calculated suspended-

Table 10.-Annual suspended-sediment loads, yields, and discharges for Black Earth Creek at Black Earth, 1954-65, and 1985-86

\begin{tabular}{ccc|c}
\hline $\begin{array}{c}\text { Water } \\
\text { year }\end{array}$ & $\begin{array}{c}\text { Total suspended- } \\
\text { sediment load } \\
\text { (tons) }\end{array}$ & $\begin{array}{c}\text { Yield } \\
\text { (tons per } \\
\text { square mile) }\end{array}$ & $\begin{array}{c}\text { Total discharge for period } \\
\text { (cubic feet per } \\
\text { second days) }\end{array}$ \\
\hline 1954 (Feb.18-Sept. 30) & 7,360 & 172 & 7,810 \\
1955 & 2,830 & 66.2 & 11,700 \\
1956 & 4,670 & 109 & 9,520 \\
1957 & 4,300 & 101 & 9,020 \\
1958 & 1,240 & 28.9 & 7,520 \\
1959 & 3,260 & 76.2 & 10,400 \\
1960 & 7,350 & 172 & 18,000 \\
1961 & 4,950 & 116 & 13,900 \\
1962 & 1,130 & 26.3 & 13,000 \\
1963 & 1,430 & 33.3 & 9,980 \\
1964 & 339 & 7.92 & 7,240 \\
1965 & 3,450 & 80.6 & 10,200 \\
1985 & 4,210 & 98.4 & 17,600 \\
1986 (Oct. 1-June 30) & 3,230 & 75.4 & 15,000 \\
Average 1955-65, 1985 & 3,260 & 76.2 & 11,500 \\
\hline
\end{tabular}


sediment yields from the various basins for this study for WY 1985-86. The USLE shows Brewery and Garfoot Creeks have the highest sediment loss, which is fairly comparable to WY 1985 suspended-sediment yield relations at the gaging stations (table 9).

\section{Total phosphorus}

Because sediment yields are, in part, related to basin slopes, and because phosphorus sorbs to sediment particles, then phosphorus yields should also be, in part, related to basin slopes. However, land-use activities and management of the land may have as great or greater influence than basin slope. Total phosphorus yield relations among the gaging stations should be approximately the same as those of suspendedsediment yield. Total phosphorus yields at the gaging stations in WY 1985 (table 9) ranged from $312 \mathrm{lb} / \mathrm{mi}^{2}$ at Black Earth Creek at Cross Plains to $628 \mathrm{lb} / \mathrm{mi}^{2}$ at Brewery Creek. Brewery Creek had the highest phosphorus concentrations during both high and low flows. The detention ponds in the Brewery Creek basin also appear to be effective in controlling phosphorus loading for small runoff events but less effective during large runoff events. If the July 25 storm load (Black Earth Creek at Cross Plains, $377 \mathrm{lb}$; Brewery Creek at Cross Plains, 1,830 lb; Garfoot Creek near Cross Plains, $747 \mathrm{lb}$; Black Earth Creek at Black Earth, 3,170 lb) is subtracted from the annual load for all gaging-station data, the following yields result: Black Earth Creek at Cross Plains, $286 \mathrm{lb} / \mathrm{mi}^{2}$; Brewery Creek, $391 \mathrm{lb} / \mathrm{mi}^{2}$; Garfoot Creek, $429 \mathrm{lb} / \mathrm{mi}^{2}$; and Black Earth Creek at Black Earth, $473 \mathrm{lb} / \mathrm{mi}^{2}$. Total phosphorus yields during WY 1986 (October 1 to June 30 only) ranged from $106 \mathrm{lb} / \mathrm{mi}^{2}$ at Black Earth Creek at Cross Plains to $454 \mathrm{lb} / \mathrm{mi}^{2}$ in the Garfoot Creek basin. Therefore, the Garfoot Creek basin (the basin with the steepest slopes) had the highest total phosphorus yield of the three upstream basins during low to moderate runoff.

Total phosphorus yields at Black Earth Creek at Black Earth increased from yields upstream (Black Earth Creek at Cross Plains and Brewery Creek) because of the higher yields from the tributary streams-Garfoot Creek and partial-record stations 4 and 5. The higher phosphorus yields at the Black Earth gaging station at Black Earth may have also been caused, in part, by phosphorus contribution from the sewagetreatment plant at Cross Plains.

\section{Total nitrogen}

Total nitrogen includes organic nitrogen, ammonia nitrogen, and nitrite plus nitrate nitrogen. Although these three components were analyzed separately, loads were calculated only for total nitrogen. Total nitrogen yields at continuous record stations during WY 1985 (table 9) ranged from $3,280 \mathrm{lb} / \mathrm{mi}^{2}$ in the Brewery Creek basin to $6,920 \mathrm{lb} / \mathrm{mi}^{2}$ in the Garfoot Creek basin. However, there was little difference among the three high yields $\left(6,110\right.$ to $\left.6,920 \mathrm{lb} / \mathrm{mi}^{2}\right)$ so yields in these basins are similar.
Total nitrogen yields during WY 1986 ranged from $1,940 \mathrm{lb} / \mathrm{mi}^{2}$ in the Brewery Creek basin to $5,690 \mathrm{lb} / \mathrm{mi}^{2}$ in the Garfoot Creek basin. Again, there was much less difference among the three high yields $\left(4,820\right.$ to $\left.5,690 \mathrm{lb} / \mathrm{mi}^{2}\right)$.

Total nitrogen yields are lower in the Brewery Creek basin and partial-record site 5 because of the small quantity of base flow (ground water) from the basin. Nitrite plus nitrate nitrogen is the predominant nitrogen component during base flow. For example, on January 19, 1985, when the discharge was all base flow, the nitrite plus nitrate nitrogen concentration was $2.4 \mathrm{mg} / \mathrm{L}$, the ammonia nitrogen concentration was $0.04 \mathrm{mg} / \mathrm{L}$, and the organic nitrogen concentration was 0.6 $\mathrm{mg} / \mathrm{L}$. Base flow in Brewery Creek during WY 1985 (fig. 5) composed only 56 percent of the total discharge for the year. In contrast, base flow at Black Earth Creek at Black Earth composed 80 percent of the total discharge for the year. Hydrograph separations were not done for Black Earth Creek at Cross Plains or Garfoot Creek, however, base flow is believed to make up a large percentage of the total discharge for the year. Streams with greater base flow have higher total nitrogen yields than those with lower base flow (table 9).

\section{Selected Water-Quality Characteristics}

\section{Water Temperature}

Water temperature was monitored continuously at the four continuous gaging stations during the 1985 and 1986 water years (fig. 1). A fifth station was monitored at Black Earth Creek downstream from a sewage-treatment plant at Cross Plains at U.S. Highway 14 and County Highway KP (fig. 1). The major factors influencing daily and seasonal water-temperature fluctuations are the temperature of ground water entering the stream, radiation, and heat exchange with the atmosphere. The temperature of the ground water is relatively constant and is near $10{ }^{\circ} \mathrm{C}$ (Novitzki, 1973). The Black Earth Creek gaging station at Cross Plains is downstream from a large ground-water discharge area, and stream temperatures are affected by these cool discharges. The maximum stream temperatures at Cross Plains are cooler during summer and warmer during winter (fig. 15) than those downstream at Black Earth because of the relatively high ground-water discharge area upstream from the temperature monitor at Cross Plains.

\section{Temperature extremes}

Water temperature fluctuates seasonally and from site to site. Seasonal maximum water temperatures are shown in figure 15. Summer temperatures increase in a downstream direction because of decreasing ground-water influence. The ranges of water temperatures at the continuous monitoring sites are shown in table 11. The maximum observed temperatures during WY 1985 ranged from $23.0^{\circ} \mathrm{C}$ at Black Earth Creek at Cross Plains to $26.5^{\circ} \mathrm{C}$ at Brewery Creek. The minimum ranged from $0.0^{\circ} \mathrm{C}$ at Brewery Creek, Gar- 
foot Creek, and Black Earth Creek at Black Earth to $2.0^{\circ} \mathrm{C}$ at Black Earth Creek at Cross Plains. The maximum daily observed water temperatures during WY 1986 ranged from $19.5^{\circ} \mathrm{C}$ at Black Earth Creek at Cross Plains to $27.0^{\circ} \mathrm{C}$ at Brewery Creek. The minimum ranged from $0.0{ }^{\circ} \mathrm{C}$ at Brewery and Garfoot Creeks to $2.0^{\circ} \mathrm{C}$ at Black Earth at Cross Plains.

The optimum temperature range for brown trout is between 16 to $18{ }^{\circ} \mathrm{C}$ (Robert Hunt, Wisconsin Department of Natural Resources, oral commun., 1987), and the upper tolerance level is from 18 to $24{ }^{\circ} \mathrm{C}$ (Alabaster and Lloyd, 1982) depending on the season, species, and stage of development. Juvenile and adult fish can usually tolerate a wider range of temperature changes than embryos. A water temperature increase in fall may adversely affect spawning and reproduction of certain salmonid species (Alabaster and Lloyd, 1982),

\section{Temperature frequency analysis}

A frequency analysis of maximum daily water temperature during WY 1985 and 1986 is shown in figure 16. The daily maximum water temperature exceeded $24{ }^{\circ} \mathrm{C}$ at Garfoot Creek, and Black Earth Creek only 1 percent of the time, and at Brewery Creek 15 percent of the time during WY 1985. The daily maximum water temperature during WY

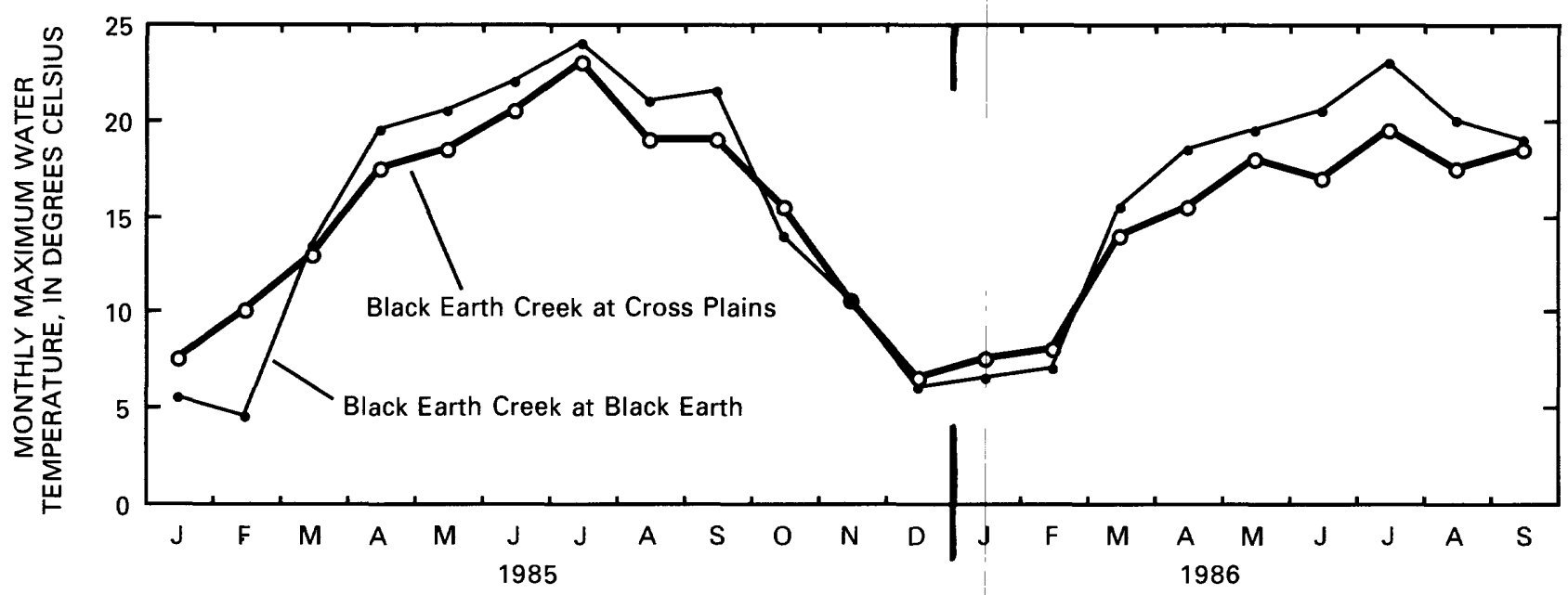

Figure 15. Monthly maximum water temperature for Black Earth Creek at Cross Plains and Black Earth.

Table 11.-Maximum, minimum, and mean water temperatures and dissolved-oxygen concentrations at the continuous monitoring stations

$\left[{ }^{\circ} \mathrm{C}=\right.$ degress Celsius; $\mathrm{mg} / \mathrm{L}=$ milligrams per liter $;-=$ data unavailable; $\min =\operatorname{minimum} ; \max =$ maximum $]$

\begin{tabular}{|c|c|c|c|c|c|c|c|c|c|c|c|c|c|c|c|}
\hline & \multicolumn{3}{|c|}{$\begin{array}{c}\text { Black Earth Creek } \\
\text { at Cross Plains } \\
05406460 \\
\end{array}$} & \multicolumn{3}{|c|}{$\begin{array}{c}\text { Brewery Creek } \\
\text { at Cross Plains } \\
\mathbf{0 5 4 0 6 4 7 0} \\
\end{array}$} & \multicolumn{3}{|c|}{$\begin{array}{c}\text { Black Earth Creek } \\
\text { at Hwy 14/KP at } \\
\text { Cross Plains } \\
05406483 \\
\end{array}$} & \multicolumn{3}{|c|}{$\begin{array}{c}\text { Garfoot Creek } \\
\text { near Cross Plains } \\
\text { 05406491 } \\
\end{array}$} & \multicolumn{3}{|c|}{$\begin{array}{c}\text { Black Earth Creek } \\
\text { at Black Earth } \\
05406500\end{array}$} \\
\hline & $\operatorname{Max}$ & Min & Mean & $\operatorname{Max}$ & Min & Mean & $\operatorname{Max}$ & Min & Mean & $\operatorname{Max}$ & Min & Mean & $\operatorname{Max}$ & Min & Mean \\
\hline & \multicolumn{15}{|c|}{1985 water year } \\
\hline $\begin{array}{l}\text { Water temperature } \\
\left({ }^{\circ} \mathrm{C}\right)\end{array}$ & 23.0 & 2.0 & 11.0 & 26.5 & 0.0 & 10.5 & - & - & - & 24.5 & 0.0 & 9.5 & 24.0 & 0.0 & 12.0 \\
\hline $\begin{array}{l}\text { Dissolved oxygen } \\
(\mathrm{mg} / \mathrm{L})\end{array}$ & 14.5 & 3.0 & 8.9 & - & - & - & - & - & - & 16.5 & 4.0 & - & - & - & - \\
\hline \multicolumn{16}{|c|}{1986 water year } \\
\hline $\begin{array}{l}\text { Water temperature } \\
\left({ }^{\circ} \mathrm{C}\right)\end{array}$ & 19.5 & 2.0 & 10.0 & 27.0 & 0.0 & 9.5 & 20.0 & 2.5 & 12.0 & 21.5 & 0.0 & 9.5 & 23.0 & 0.5 & 10.0 \\
\hline $\begin{array}{l}\text { Dissolved oxygen } \\
(\mathrm{mg} / \mathrm{L})\end{array}$ & 16.1 & 4.9 & 9.3 & - & - & - & 16.3 & 5.2 & 9.7 & - & - & - & 18.9 & 4.8 & - \\
\hline
\end{tabular}


1986 was less than $24^{\circ} \mathrm{C}$ at Garfoot Creek, and Black Earth Creek at Cross Plains and Black Earth. The maximum water temperature exceeded $24{ }^{\circ} \mathrm{C} 7$ percent of the time at Brewery Creek.
During the summer (July-August) water temperatures as shown in figure 17 were often within the range of optimum water temperature for trout $\left(16-18^{\circ} \mathrm{C}\right)$ (Robert Hunt, Wisconsin Department of Natural Resources, oral commun., 1987).
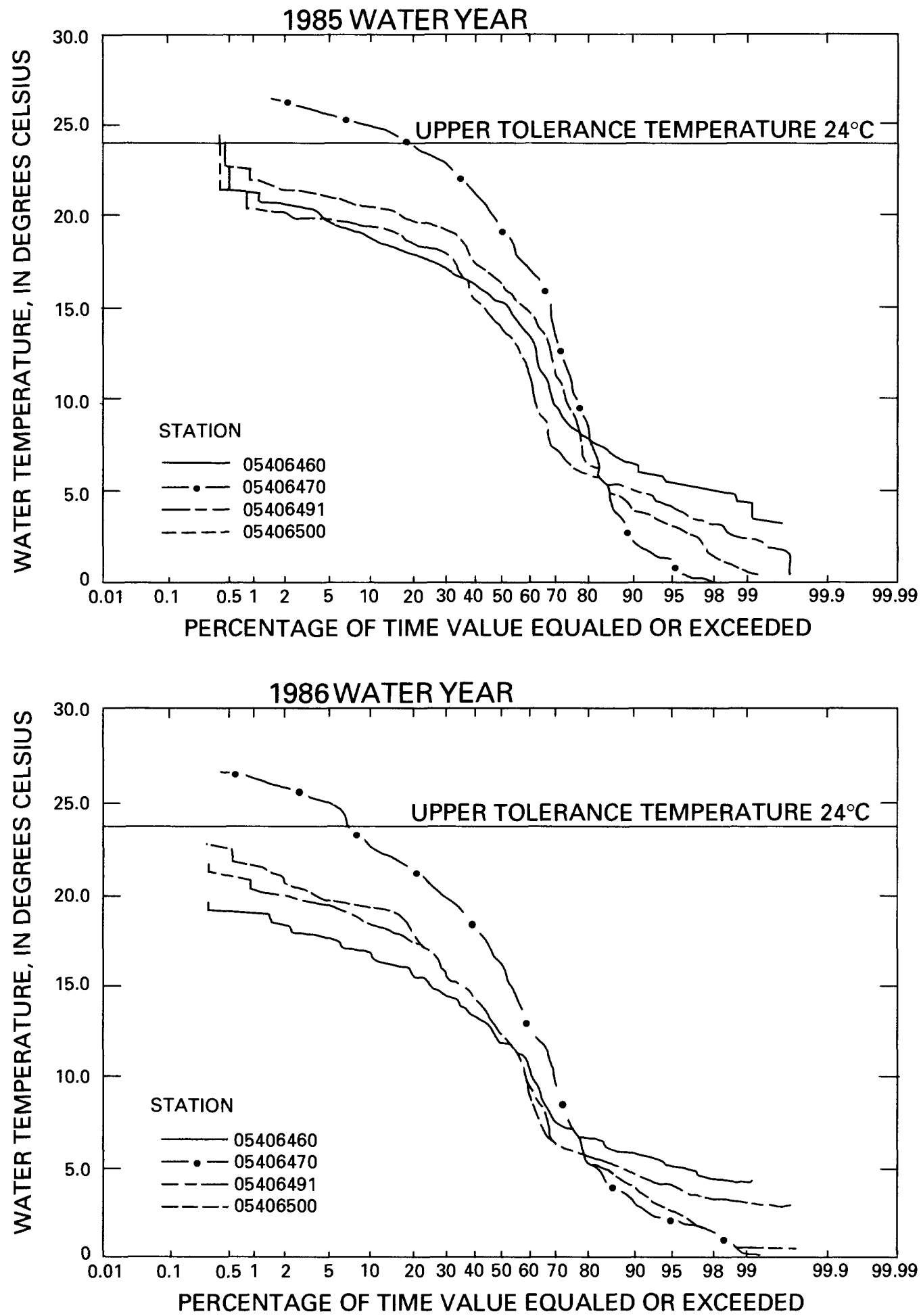

Figure 16. Percentage of time maximum daily water temperature was equaled or exceeded, 1985 and 1986 water years. 
During the summer of WY 1985, Black Earth Creek at Cross Plains had water temperatures (during some unspecified time period) within the optimum range 76 percent of the days. Garfoot Creek and Black Earth Creek at Black Earth had water temperatures (during some unspecified time period) within the optimum range 81 and 83 percent of the days, respectively. Brewery Creek never had summer temperatures less than $16^{\circ} \mathrm{C}$ and had maximum temperatures above $24{ }^{\circ} \mathrm{C}$, the upper threshold for trout, 30 percent of the time. Garfoot Creek had maximum summer temperatures above $24^{\circ} \mathrm{C}$ less than 2 percent of the time.

During the summer of WY 1986 Black Earth Creek at Cross Plains had optimal water temperatures for trout (for an unspecified time period) 61 percent of the days; Garfoot
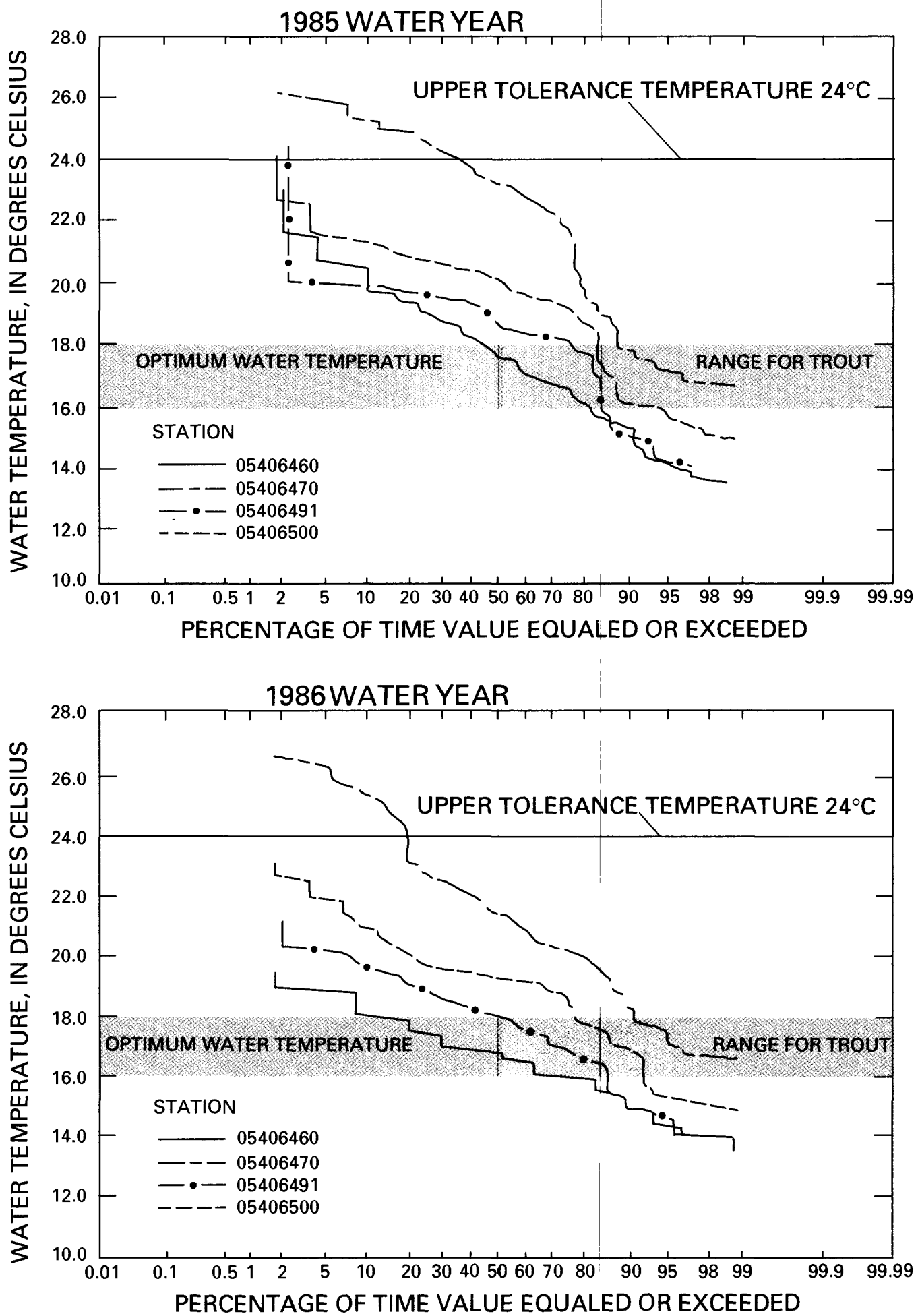

Figure 17. Percentage of time summer daily maximum (July-August) water temperature was equaled or exceeded, 1985 and 1986 water years. 
Creek and Black Earth Creek at Black Earth had water temperatures in the optimal range (for an unspecified time period) 81 and 83 percent of the time, respectively. Brewery Creek never had water temperatures below $16^{\circ} \mathrm{C}$, and water temperatures were above the $24^{\circ} \mathrm{C}$ (the upper threshold limit) 19 percent of the time.

The summer water temperatures are lower in Black Earth Creek and Garfoot Creek because of relatively high ground-water inflow. In contrast, water temperatures are higher in Brewery Creek because ground-water inflow is a smaller component of streamflow. Brewery Creek would be unsuitable as spawning habitat for trout because of its high water temperature even if the substrate for spawning were present.

\section{Effects of gravel-pit discharge on water temperature}

The gravel-pit operation upstream from Cross Plains discharges warm water to Black Earth Creek and may have an adverse effect on trout populations. Temperature increases of 5 to $6{ }^{\circ} \mathrm{C}$ in the fall or winter may result in higher embryo mortality in trout (Alabaster and Lloyd, 1982). Any water temperature increase in summer above the temperature of 20 to $21{ }^{\circ} \mathrm{C}$ can be harmful to trout. On May 7, 1986, the temperature of gravel-pit discharge was $14.5^{\circ} \mathrm{C}$. At the same time, the stream temperature in Black Earth Creek upstream from the gravel-pit discharge was $11{ }^{\circ} \mathrm{C}$; downstream at the Black Earth Creek at Cross Plains gaging station the water temperature was $12.3{ }^{\circ} \mathrm{C}$.

Stream temperatures at the gaging station in Cross Plains, under natural low-flow conditions, are cooler in summer because of high ground-water discharge between the gaging station and the gravel pit. The effect of the warm discharge from the gravel pit on the stream water temperature is shown in figure 18. The effect of pumping is more apparent from the minimum (nighttime) water temperature because solar radiation and air temperature fluctuations during daytime cause variations in the water temperature maximums that mask the effects of pumping. The gravel-pit discharge increased nighttime water temperature about $2.5^{\circ} \mathrm{C}$ on July 12 and 13,1985 , and $3.8^{\circ} \mathrm{C}$ on July 18,1985 (fig. 18) at Cross Plains. The effects of these warm discharge waters from the gravel pit are barely discernible at the gaging station at Black Earth. Novitzki (1973) found that minimum temperatures increased $1{ }^{\circ} \mathrm{C}$ at the Black Earth Creek at Cross Plains gaging station in response to the gravel-pit discharge, but he also found negligible affects at the Black Earth Creek gaging station at Black Earth. As a result of these warm-water discharges from the gravel-pit operation, the warm-water effluent in the fall, winter, and spring may not affect the fishery. However, increased water temperature during the critical

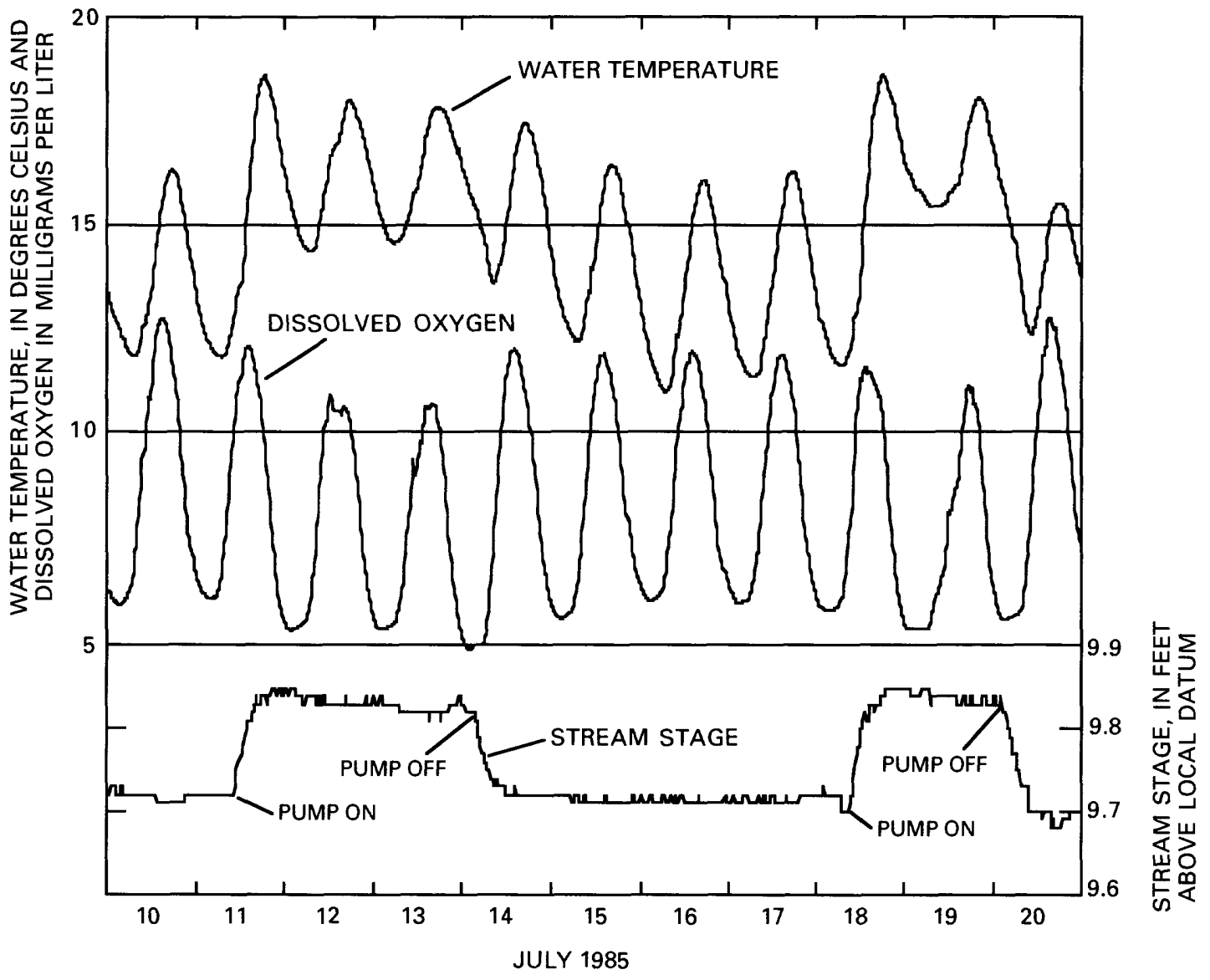

Figure 18. Stream stage, temperature, dissolved-oxygen concentration, and pumping warm water from gravel pit. 
summer period may adversely affect the fishery. It is not known what effects, if any, these warm discharges have on macrophyte growth.

\section{Water-temperature model}

A simplified water-temperature model was run to determine if lowering the pump intake to the cooler water near the bottom of the pond could lower the stream temperature. When water of different temperatures is mixed, such as when water from the pond is pumped to the stream, the temperature of the mixture will equilibrate at some intermediate value. The temperature of the mixture will equilibrate with air temperature, but will not normally reach air temperatures. The differences between air and water temperatures decrease downstream because the increased traveltime allows more time for heat exchange and equilibration (Novitzki, 1973).

The model uses two equations, one that describes the change in water temperature downstream and another that describes the effect of ground-water runoff on stream temperature. The equations were solved to determine streamwater-temperature profiles caused by the mixing of stream water and water from the pond. A series of streamflow measurements in the reach downstream from the pond were made to determine the amounts and locations of ground-water inputs to the stream. These measurements were used to calibrate the model and predict stream-water temperature at three sites downstream from the gravel pit. The calibrated model was tested by attempting to predict actual temperatures observed at downstream sites. The predicted water temperature (table 12) was $0.82^{\circ} \mathrm{C}$ lower than the observed water temperature at County Trunk $\mathrm{P}$ and $0.45^{\circ} \mathrm{C}$ less than that observed at low-flow site 7 (fig. 1). Predicted and observed temperatures agreed at Black Earth Creek at Black Earth.

The water-temperature model was run using two different hypothetical water temperatures for the pond discharge. Water temperatures of $10^{\circ} \mathrm{C}$ and $20^{\circ} \mathrm{C}$ were used and the results can be found in table 13 . The temperature of $10^{\circ} \mathrm{C}$ was chosen to approximate that of ground-water discharge and the bottom pond water temperature. A temperature of $20{ }^{\circ} \mathrm{C}$ was chosen to approximate present conditions.

The model results indicate that augmentation of the flow with colder water will have the most effect on the stream just below the pump and will not improve the temperature downstream from Black Earth. Novitzki (1973) found essentially the same results, with the effect of augmentation negligible $2.35 \mathrm{mi}$ downstream from the augmentation point. The model was calibrated with the stream temperature of $12{ }^{\circ} \mathrm{C}$ and may not be representative of summertime maximums.

\section{Dissolved Oxygen}

Dissolved oxygen is an essential element for aquatic life. Dissolved-oxygen concentrations may be depleted by processes that consume dissolved, suspended or precipitative organic matter (Hem, 1985). Aquatic macrophytes consume oxygen by respiring at night but produce oxygen by photosynthesis during the day. Dissolved-oxygen requirements differ from species to species, life stages, and life processes. Stream standards typically specify a minimum level of $5 \mathrm{mg} / \mathrm{L}$. A more meaningful criteria would be a minimum value that is equaled or exceeded for specified durations during the year. For salmonids, the annual average values should be $9 \mathrm{mg} / \mathrm{L}$ for 50 percent of the time and not less than $5 \mathrm{mg} / \mathrm{L}$ for 5 percent of the time (Alabaster and Lloyd, 1982).

\section{Dissolved-oxygen extremes}

Dissolved-oxygen concentrations were monitored at two sites from March through September 1985: Black Earth Creek at Cross Plains and Garfoot Creek at Cross Plains (fig. 1). Dissolved-oxygen concentrations were monitored at three sites from February through September 1986. All three sites were on Black Earth Creek: the gaging station at Cross Plains, State Highway 14 and County Highway KP below the sewagetreatment plant at Cross Plains, and the gaging station at Black Earth.

The maximum dissolved-oxygen concentration measured at stations on Black Earth Creek during WY 1986 ranged from $16.1 \mathrm{mg} / \mathrm{L}$ at Cross Plains to $18.9 \mathrm{mg} / \mathrm{L}$ at Black Earth (table 11). The minimum ranged from $4.8 \mathrm{mg} / \mathrm{L}$ at Black Earth to $5.2 \mathrm{mg} / \mathrm{L}$ at Highway 14 and County Highway KP.

The DNR standard for minimum dissolved-oxygen concentrations for cold-water (trout) fisheries is $7 \mathrm{mg} / \mathrm{L}$ during spawning periods (usually October and November) and $6 \mathrm{mg} / \mathrm{L}$ for other periods. Dissolved-oxygen concentrations measured in both Garfoot and Black Earth Creeks during WY 1985 and 1986 were below State standards at times. The dissolved-oxygen concentration fell below the $6 \mathrm{mg} / \mathrm{L}$ standard 28 times during WY 1985 at Black Earth Creek at Cross Plains and twice at Garfoot Creek. The dissolvedoxygen concentration fell below the $6 \mathrm{mg} / \mathrm{L}$ standard 23 times during WY 1986 at Black Earth Creek at Cross Plains, twice at Black Earth Creek at Highway 14 and County Highway $\mathrm{KP}$, and 21 times at Black Earth Creek at Black Earth.

Dissolved-oxygen concentrations fell below the $6 \mathrm{mg} / \mathrm{L}$ standard at Black Earth Creek at Cross Plains and Black Earth because of a combination of factors in Black Earth Creekmacrophyte biomass respiration and increased water temperatures from the discharge of the gravel-pit operation and agricultural runoff. The macrophyte biomass was lowest at the Highway 14 and County Highway KP sites during both 1985 and 1986 as compared to sites near Cross Plains and Black Earth (fig. 8). Increased biomass respiration causes a greater dissolved-oxygen reduction at night. The site at the upstream edge of Cross Plains at County Trunk P had large dissolved-oxygen fluctuations $(5$ to $6 \mathrm{mg} / \mathrm{L}$ ) because of photosynthesis and respiration from dense macrophyte biomass. The increased water temperatures caused by discharges from the gravel-pit operation also contribute to 
lower dissolved-oxygen concentrations by decreasing solubility.

\section{Dissolved-oxygen frequency analysis}

Expressing a standard as a percentage of times a value is equaled or exceeded is another alternative to a single standard. Alabaster and Lloyd (1982) suggest for salmonid populations that the minimum dissolved-oxygen concentration should exceed $9 \mathrm{mg} / \mathrm{L}$ at least 50 percent of the time and should not fall below $5 \mathrm{mg} / \mathrm{L}$ longer than 5 percent of the time.
The minimum dissolved oxygen during WY 1985 exceeded $9 \mathrm{mg} / \mathrm{L}$ less than 1 percent of the time at Black Earth Creek at Cross Plains and about 13 percent of the time at the Garfoot Creek site (fig. 19). The minimum dissolved oxygen was less than $5 \mathrm{mg} / \mathrm{L}$ at Black Earth Creek at Cross Plains about 10 percent of the time, and at Garfoot Creek the minimum dissolved oxygen was less than $5 \mathrm{mg} / \mathrm{L}$ about 3 percent of the time (fig. 19). The low minimum dissolvedoxygen concentration at the Cross Plains site is likely because of oxygen consumption by the respiration of dense macrophytes near this site.

Table 12.-Computation to determine response coefficient, $k$

$\left[{ }^{\circ} \mathrm{C}=\right.$ degrees Celsius; $\mathrm{ft}^{3} / \mathrm{s}=$ cubic feet per second $]$

\begin{tabular}{|c|c|c|c|c|c|c|c|c|c|c|c|}
\hline \multirow[t]{2}{*}{ Site } & \multirow[t]{2}{*}{ WL } & \multirow[t]{2}{*}{$\mathbf{T I}$} & \multirow[t]{2}{*}{ kWL } & \multirow[t]{2}{*}{$e^{-k W}$} & \multirow[t]{2}{*}{ Ts } & \multirow[t]{2}{*}{ Qs } & \multirow[t]{2}{*}{ Qgw } & \multirow[t]{2}{*}{ Tgw } & \multirow[t]{2}{*}{$\mathbf{T L}$} & \multicolumn{2}{|c|}{ Water temperature $\left({ }^{\circ} \mathbf{C}\right)$} \\
\hline & & & & & & & & & & Computed & Observed \\
\hline Low-flow site 3 & 0.00 & 11.80 & & & & & & & & & \\
\hline Mixing reach & .10 & 11.80 & 0.02 & 0.98 & 11.62 & 3.48 & 5.00 & 8.30 & 9.66 & 13.14 & \\
\hline Low-flow site 4 & 1.14 & 9.66 & .15 & .86 & 8.34 & 8.48 & 4.12 & 11.80 & 9.47 & 13.33 & \\
\hline County P (05406460) & .55 & 9.47 & .07 & .93 & 8.83 & 12.60 & 5.40 & 11.80 & 9.72 & 13.08 & 14.0 \\
\hline \multicolumn{12}{|l|}{ Mixing reach below } \\
\hline Brewery Creek & .10 & 9.72 & .01 & .99 & 9.60 & 18.00 & 3.10 & 6.80 & 9.19 & 13.61 & \\
\hline Low-flow site 6 & .70 & 9.19 & .09 & .92 & 8.43 & 21.20 & 1.20 & 11.80 & 8.61 & 14.19 & \\
\hline Low-flow site 7 & .94 & 8.61 & .11 & .90 & 7.73 & 22.30 & 3.30 & 11.80 & 8.25 & 14.55 & 15.0 \\
\hline Low-flow site 8 & 1.08 & 8.25 & .12 & .89 & 7.33 & 25.60 & 2.00 & 11.80 & 7.65 & 15.15 & \\
\hline \multicolumn{12}{|l|}{ Mixing reach above } \\
\hline Garfoot Creek & .41 & 7.65 & .04 & .96 & 7.34 & 27.60 & 2.58 & 11.80 & 7.72 & 15.08 & \\
\hline \multicolumn{12}{|l|}{ Mixing reach below } \\
\hline Garfoot Creek & .10 & 7.72 & .01 & .99 & 7.64 & 30.20 & 5.90 & 5.80 & 7.34 & 15.46 & \\
\hline Low-flow site 9 & .21 & 7.34 & .02 & .98 & 7.19 & 36.10 & 1.32 & 11.80 & 7.35 & 15.45 & \\
\hline Low-flow site 10 & 1.39 & 7.35 & .14 & .87 & 6.41 & 37.40 & 4.90 & 11.80 & 7.04 & 15.76 & \\
\hline \multicolumn{12}{|l|}{ Black Earth Creek } \\
\hline$(05406500)$ & 1.68 & 7.04 & .16 & .85 & 6.01 & 42.30 & 6.70 & 11.80 & 6.80 & 16.00 & 16.0 \\
\hline
\end{tabular}

Maximum air temperature

Maximum water temperature at low-flow site 3 above augmentation site-

Ground-water temperature of augmentation-_-_-_-_-_-_ $14.5^{\circ} \mathrm{C}$

Streamflow above augmentation point-_-_-_-

Augmentation flow'-_-_

Ground-water temperature ${ }^{2}-$

WL $=$ Length increment between low-flow sites

Ti (for first step) = Air temperature minus stream temperature

$\mathrm{Ti}$ (for subsequent steps) $=\mathrm{Tl}$ from preceding steps

$\mathrm{Tgw}=$ air temperature minus ground-water temperature

Qs = streamflow volume, in cubic feet per second, at upper end of stream increment

Qgw = ground-water runoff, in cubic feet per second, occurring within stream increment

$\mathbf{k}=$ response coefficient

Ts $=$ Ti $\mathrm{e}^{-\mathrm{kWL}}$

$\mathrm{TL}=\frac{\mathrm{Qs}(\mathrm{Ts})+\mathrm{Qgw}(\mathrm{Tgw})}{\mathrm{Qs}+\mathrm{Qgw}}$

'From streamflow records at Black Earth Creek at County P.

${ }^{2}$ Typical Wisconsin ground-water temperature. 
The minimum dissolved-oxygen concentration during WY 1986 exceeded $9 \mathrm{mg} / \mathrm{L} 13$ percent of the time at Cross Plains, 25 percent of the time at State Highway 14 and County Highway KP, and 20 percent of the time at Black Earth (fig. 19). The minimum dissolved-oxygen concentration was less than $5 \mathrm{mg} / \mathrm{L} 2$ percent of the time at Cross Plains and less than 1 percent of the time at Black Earth. The minimum dissolved-oxygen concentration was never less than $5 \mathrm{mg} / \mathrm{L}$ at State Highway 14 and County Highway KP (fig. 19). The observed minimum dissolved-oxygen concentrations were higher in WY 1986 than WY 1985.

A large storm in July 1985 may have scoured the stream bottom and removed the macrophytes and suitable substrate, thereby reducing the biomass in 1986 as compared to 1985 . This reduced biomass of macrophytes would consume less oxygen during respiration, and hence there would be less dissolved-oxygen consumption at night; the dissolved oxygen minimum at Black Earth Creek at Cross Plains was greater than $9 \mathrm{mg} / \mathrm{L} 13$ percent of the time in WY $1986 \mathrm{com}$ pared to only 1 percent of the time in WY 1985.

\section{Effects of gravel-pit discharge}

\section{on dissolved-oxygen concentration}

The warm water discharged from the gravel-pit pond also caused instream dissolved-oxygen concentrations to decrease. Dissolved-oxygen solubility in water decreases with increasing water temperature. For example, at an atmospheric pressure of $730 \mathrm{~mm}$ (millimeter), water at a temperature of $12{ }^{\circ} \mathrm{C}$ can hold $10.3 \mathrm{mg} / \mathrm{L}$ of dissolved oxygen; at a temperature of $16{ }^{\circ} \mathrm{C}$, water can hold $9.5 \mathrm{mg} / \mathrm{L}$. Therefore, the increased water temperatures from the gravel-pit pond not only cause stream temperatures to increase but also decrease maximum dissolved-oxygen solubility in water by about $1 \mathrm{mg} / \mathrm{L}$. This was observed frequently throughout the summer periods. A combination of the large diurnal fluctuation in dissolved oxygen caused by nighttime respiration by dense aquatic macrophytes upstream (fig. 18) and the warmer water temperatures due to the gravel-pit discharge cause minimum oxygen concentrations to be less than the Wisconsin State standard for trout streams $(6 \mathrm{mg} / \mathrm{L})$.

\section{Instream dissolved-oxygen reduction during storms}

Storm runoff from farmland may contain organic matter that has high oxygen demand, which results in a reduction in the dissolved-oxygen concentration of the receiving stream. This has been observed in streams in southwestern Wisconsin (Field, 1986), and it also was observed in Black Earth Creek following summer rainstorms. Dissolved-oxygen reductions were recorded during a number of storms in WY 1985 and were observed at all sites with continuous dissolvedoxygen recorders. The largest decrease in dissolved-oxygen concentration occurred on July 25, 1985, at Black Earth Creek at Cross Plains. The stream discharge increased from about $10 \mathrm{ft}^{3} / \mathrm{s}$ to a maximum discharge of $122 \mathrm{ft}^{3 / s}$ as a result of

Table 13.-Model results with two different augmentation temperatures

$\left[{ }^{\circ} \mathrm{C}\right.$, degrees Celsius $]$

\begin{tabular}{|c|c|c|c|}
\hline Site & $\begin{array}{c}\text { Water temperature } \\
\text { at } 10^{\circ} \mathrm{C} \\
\text { augmentation }\end{array}$ & $\begin{array}{c}\text { Water temperature } \\
\text { at } 20{ }^{\circ} \mathrm{C} \\
\text { augmentation }\end{array}$ & $\begin{array}{c}\text { Observed } \\
\text { water } \\
\text { temperature }\end{array}$ \\
\hline Low-flow site 3 & 11.80 & 11,80 & \\
\hline Mixing reach & 10.49 & 16.38 & \\
\hline Low-flow site 4 & 12.07 & 15.02 & \\
\hline County P & 12.32 & 14.12 & 14.0 \\
\hline $\begin{array}{l}\text { Mixing reach below } \\
\text { Brewery Creek }\end{array}$ & 12.99 & 14.48 & \\
\hline Low-flow site 6 & 13.69 & 14.88 & \\
\hline Low-flow site 7 & 14.20 & 15.04 & 15.0 \\
\hline Low-flow site 8 & 14.90 & 15.51 & \\
\hline $\begin{array}{l}\text { Mixing reach above } \\
\text { Garfoot Creek }\end{array}$ & 14.87 & 15.38 & \\
\hline $\begin{array}{l}\text { Mixing reach below } \\
\text { Garfoot Creek }\end{array}$ & 15.29 & 15.71 & \\
\hline Low-flow site 9 & 15.29 & 15.68 & \\
\hline Low-flow site 10 & 15.66 & 15.92 & \\
\hline Black Earth Creek & 15.94 & 16.10 & 16.0 \\
\hline
\end{tabular}


5.54 in. of rain on July 24 and 25 . A graph of stream discharge and dissolved-oxygen concentration for Black Earth Creek at Cross Plains for the period July 23 through July 26 is shown in figure 20. As streamflow began to increase, the dissolvedoxygen concentration began to decrease and stream temperature began to rise. The peak discharge occurred at approximately 1200 hours on July 25 , and the lowest dissolved-oxygen concentration occurred at approximately 2100 hours or 9 hours later. The dissolved-oxygen concentration decreased from 12.1 to $3.9 \mathrm{mg} / \mathrm{L}$ during a period when
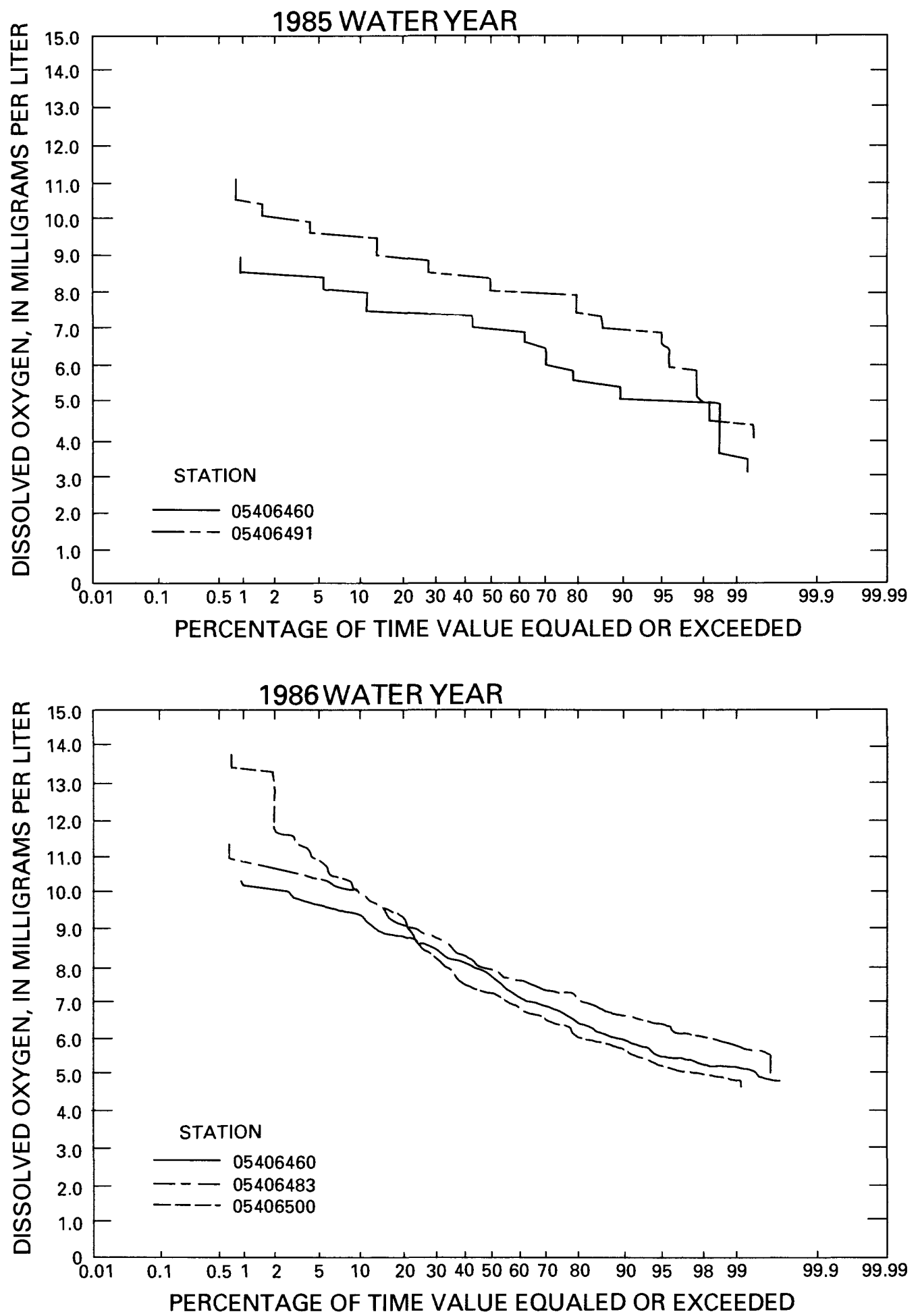

Figure 19. Percentage of time daily minimum dissolved-oxygen concentration was equaled or exceeded, 1985 and 1986 water years. 


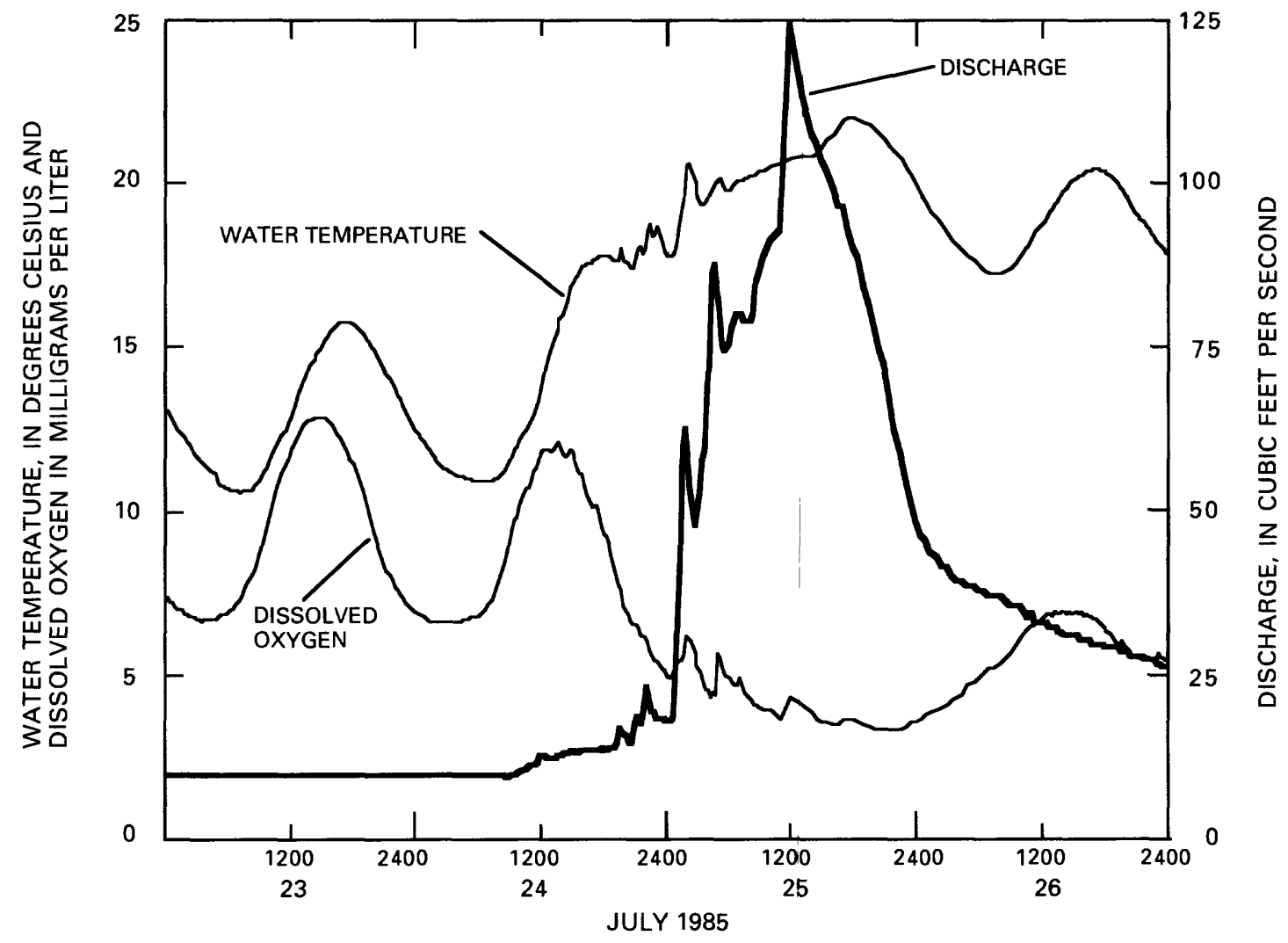

Figure 20. Streamflow, water temperature, and dissolved-oxygen concentration, July 23-26, 1985, at Black Earth Creek at Cross Plains.

daily maximum values normally occur. The 5-day BOD was only $5.5 \mathrm{mg} / \mathrm{L}$, at a discharge of $86 \mathrm{ft}^{3} / \mathrm{s}$, at 0916 hours on July 25,1985 . The dissolved-oxygen concentration dropped to $3.0 \mathrm{mg} / \mathrm{L}$, stayed below $4.0 \mathrm{mg} / \mathrm{L}$ for 21 hours, and stayed below $6.0 \mathrm{mg} / \mathrm{L}$ (the minimum State standard for dissolved oxygen in trout streams) for 30 hours. Although dissolved oxygen was low there were no fishkills reported from this event, and no fishkills were observed during the study period.

Two other reductions in dissolved-oxygen concentrations were observed during the WY 1985. The dissolvedoxygen concentration at Garfoot Creek decreased from a minimum of $8.0 \mathrm{mg} / \mathrm{L}$ on July 23 to $4.5 \mathrm{mg} / \mathrm{L}$ on July 25 . At Black Earth Creek at Cross Plains on September 4 and 5 , the stream discharge increased from 12 to $21 \mathrm{ft}^{3} / \mathrm{s}$, with a resultant decrease in the dissolved-oxygen concentration from 6.7 to $4.9 \mathrm{mg} / \mathrm{L}$. Minimums on July 23 and 24 and September 4 and 5 occurred when agricultural runoff was entering the stream.

Fewer dissolved-oxygen reductions caused by runoff events occurred during WY 1986. However, a measurable reduction was observed during one runoff period, July 10-12, 1986. The discharge at the gage at Cross Plains increased from $15 \mathrm{ft}^{3} / \mathrm{s}$ on July 10 to $30 \mathrm{ft}^{3 /} / \mathrm{s}$ on July 11,1986 , and resulted in a dissolved-oxygen minimum on July 11 of $5.4 \mathrm{mg} / \mathrm{L}$. The maximum dissolved-oxygen concentration on July 11 was only $7.5 \mathrm{mg} / \mathrm{L}$, which was almost $3 \mathrm{mg} / \mathrm{L}$ less than the maximum recorded on July 9. The decrease in dissolved oxygen also was recorded as it moved downstream. The minimum dissolved oxygen at Highway 14 and County Highway KP dropped to $6.5 \mathrm{mg} / \mathrm{L}$ on July 11 .

Biochemical oxygen demand for the study streams was moderately high during periods of overland runoff. Concentrations ranged from 5.5 to $38 \mathrm{mg} / \mathrm{L}$. Biochemical oxygen demand was higher during winter storm runoff than during summer storm runoff. Biochemical oxygen demand during winter runoff, February 22, 1985, ranged from $16 \mathrm{mg} / \mathrm{L}$ at Black Earth Creek at Cross Plains, at a discharge of $16 \mathrm{ft}^{3} / \mathrm{s}$, to $38 \mathrm{mg} / \mathrm{L}$ at Brewery Creek, at a discharge of $32 \mathrm{ft}^{3} / \mathrm{s}$. During the July 25, 1985, storm, however, BOD was much lower and ranged from $5.5 \mathrm{mg} / \mathrm{L}$ at Black Earth Creek at Cross Plains (at a discharge of $86 \mathrm{ft}^{3} / \mathrm{s}$ ) to $8.6 \mathrm{mg} / \mathrm{L}$ at Brewery Creek (at a discharge of $146 \mathrm{ft}^{3} / \mathrm{s}$ ). Although the BOD in the study streams was high, the sharp declines in the dissolvedoxygen concentrations, such as those at Black Earth Creek at Cross Plains on July 25, 1985 (fig. 20), are not characteristic of dissolved-oxygen reductions caused by BOD. High BOD characteristically causes gradual declines, measured over days, in the dissolved-oxygen levels in a stream. It seems unlikely that BOD is the sole cause of the reduction.

The authors theorize that the dissolved-oxygen reductions are likely caused by a combination of factors including: 
BOD, water temperature (fig. 20), an immediate chemicaloxygen demand (COD) from mixing of the bed material into the water column by scour, agricultural runoff containing reduced organic materials, and interruption of photosynthesis because of high turbidity and light inhibition. Oxidizable organic material deposited, in the streambed as velocities slow after runoff events and during low-flow periods, decays and becomes part of the sediment-oxygen demand. When stream velocities increase during the next rainstorm, this anerobic organic material is scoured from the streambed; it creates an immediate oxygen demand on the water column and depresses the dissolved-oxygen concentration. Reduced chemical constituents carried in overland runoff are likely to have a high COD as well, and may contribute to dissolvedoxygen reduction.

Although dissolved-oxygen reductions did not cause fishkills, the depressed oxygen concentration is still a concern. Low dissolved-oxygen concentrations can increase the toxicity of un-ionized ammonia to rainbow trout (Downing and Merkins, 1955). There have been severe fishkills in other streams in Wisconsin that may have been caused by depletion of dissolved oxygen (Field, 1986). The synergistic effect of low dissolved-oxygen concentration and subcritical, high concentrations of other constituents, such as un-ionized ammonia, suspended sediment, and pesticides, could cause a fishkill.

\section{HYDROLOGIC FACTORS AFFECTING TROUT POPULATIONS}

Trout populations appear to vary with streamflow, which, in turn, responds to precipitation and ground-water discharge (inflow). Low streamflow can decrease living space and the availability of cover for trout. In contrast, high base flow increases living space, decreases water temperatures, and may also increase dissolved oxygen. Relations between streamflow and fish production have been shown by several researchers (Dunst, 1970; Hendrickson and Doonan, 1972; White, 1972). On the basis of 9 years of data, Dunst (1970) found a relation between brown trout fingerling populations and average streamflow for the preceding year in Black Earth Creek (correlation coefficient 0.815 ). The University of Wisconsin Management Workshop (Institute for Environmental Studies, 1986) extended Dunst's linear relation for 1969, 1970, 1981, 1983, and 1984 data, but found a less direct association (correlation coefficient 0.33 ).

Although large fluctuations in the annual mean stream discharge in Black Earth Creek at Black Earth have occurred since records began in 1954 (fig. 21a), a general increasing discharge trend has been observed since 1965 .

Figure 21a shows the annual mean discharges and the 3-year moving mean discharge for Black Earth Creek. The 3-year moving mean discharge "dampens" the annual variability. The annual 7-day mean summer low flow, which represents base flow or ground water discharging to the stream, and its 3-year moving mean are also shown in figure $21 \mathrm{~b}$.

The 7-day mean summer (fig. 21b) low flow also shows the same general increase in streamflow as the annual mean discharge. This indicates that not only have mean discharges generally increased, but base flows (ground-water discharge) have increased accordingly. Trout populations appear to follow the annual streamflow fluctuations (fig. 21c).

Base flow of the streams is increasing apparently because of a rise in ground-water levels. Ground-water levels in Iw-110, a water-table well in the sandstone aquifer $10 \mathrm{mi}$ west of Black Earth, illustrates this rise (fig. 21d). Although the well lies outside the Black Earth Creek basin, it is the only water-table well nearby and should be indicative of the rise and fall of annual water-table elevations in the basin.

Annual ground-water levels since 1968 have generally shown a rise because of ground-water recharge resulting from greater than normal annual precipitation. The rise (or fall) in ground-water levels has been shown to be fairly well related to the rise (or fall) in the departure from normal precipitation (Audini and others, 1959; LeRoux, 1963; Vanlier, 1963). This relation is shown by comparing the ground-water levels in Iw-110 (fig. 21d) to the cumulative departure of precipitation from normal for data from the U.S. Weather Bureau station at Madison for the period 1954-86 (fig. 21e). The cumulative departure of precipitation from normal for the period of record 1931-86 (fig. 21f) also is shown to explain why base flow was so low in the late 1950's and 1960's. Anomalous short-term trend differences in figures $21 \mathrm{~d}$ and 21e (that is, 1968-72) are likely the result of annual precipitation at Madison, 25 mi east of well Iw-110, not being representative of the annual precipation affecting ground-water levels at Iw-110.

Trout populations (excluding fingerlings) in Black Earth Creek generally have fluctuated with streamflow (fig. 22). A regression analysis was made for Black Earth Creek between the estimated annual trout population (done by constructing a line averaging the spring and fall trout population) and the 3-year moving annual mean discharge; the correlation coefficient was 0.75 with a standard error of 83 percent. The trout population data presented in figure 22 indicate that since 1977 the trout population appears to have reached a relatively stable number. This may indicate that perhaps the stream has reached its carrying capacity; the carrying capacity is the maximum number of organisms that can be supported by a stream ecosystem. However, extreme sedimentation of the channel bed of Black Earth Creek downstream from Brewery Creek in 1983 may have severely inhibited reproduction because no increase in population occurred after 1983. This heavy sedimentation from Brewery Creek covered prime spawning habitat and destroyed trout redds (Scott Stewart, Wisconsin Department of Natural Resources, oral commun., 1988).

The Wisconsin Department of Natural Resources data from DNR trout sampling reaches (fig. 1) indicated that the 
trout fingerling population in the reach in close proximity of Brewery Creek (stations 99-95) decreased from 2,500 fingerlings per mile in 1981, to 1,800 in 1983 , and to 500 in 1984 (Institute for Environmental Studies, 1986). In 1983 after the heavy sedimentation, reproduction at stations 99-95 declined, but reproduction downstream at stations 11-1 and 19-12 increased. By 1984 a decrease in reproduction occurred in all DNR trout sampling reaches, although the decrease in the upper two reaches was considerably greater than the
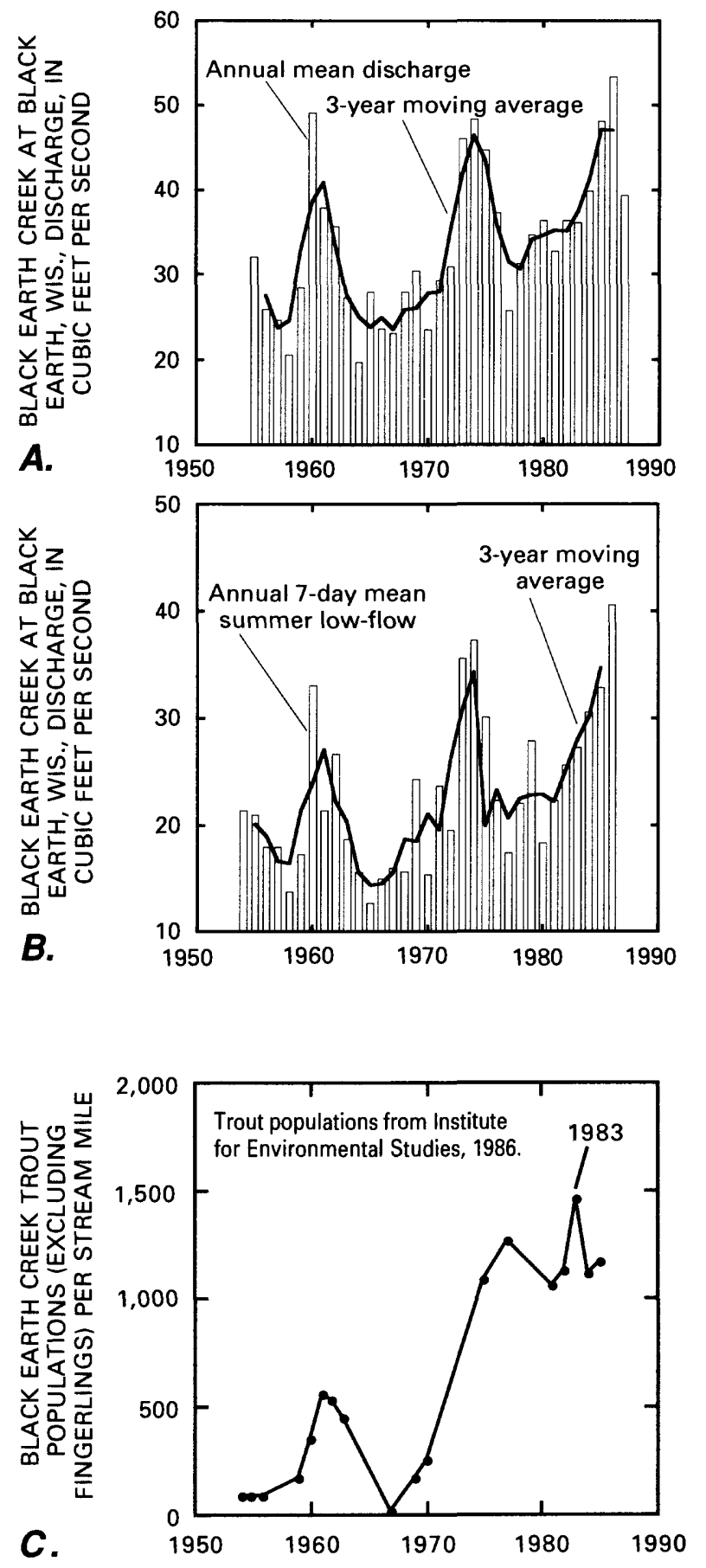

decrease in the lower reach. Sediment bedload migrating downstream and destroying spawning areas at stations 11-1 and 19-12 in 1984 may have decreased reproduction downstream.

Other factors worth noting that have likely affected the trout population in previous years are:

- A new sewage-treatment plant in Cross Plains in 1969. Additional upgrading in that plant in 1982 (Institute for Environmental Studies, 1986).
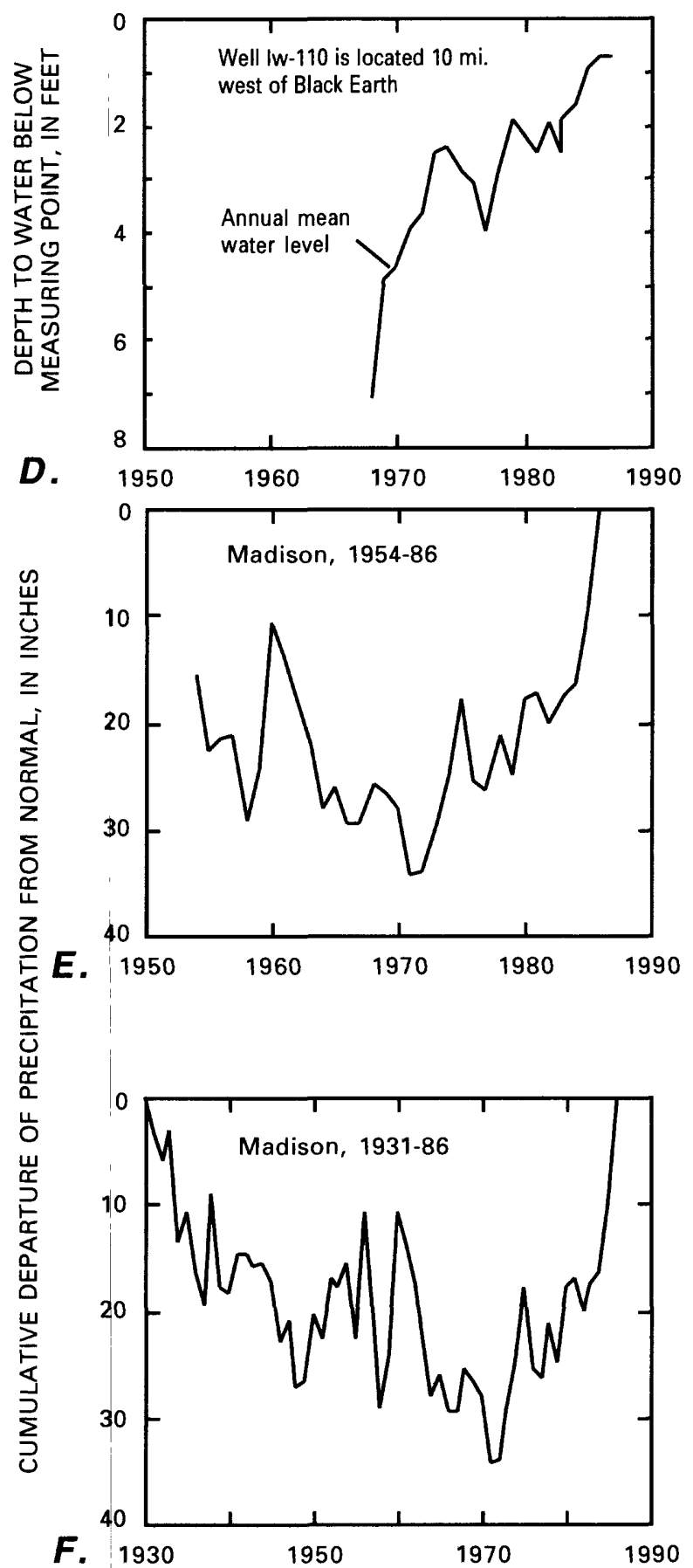

Figure 21. Streamflow, annual mean discharge, trout populations, ground-water levels, and cumulative departure of precipitation from normal, for Black Earth Creek basin. 
- Changes in fish management. Until the late 1960's Black Earth Creek was stocked with hatchery brown trout. By 1975 the number of hatchery fish stocked was negligible (Institute for Environmental Studies, 1986).

- Increases in land acquisition and habitat improvement starting in 1949 (Wisconsin Department of Natural Resources, 1982).

- Removal of the Cross Plains mill pond in 1956.

\section{SUMMARY AND CONCLUSIONS}

Black Earth Creek is a highly productive trout stream in southern Wisconsin. Despite increasing trout populations, there are indications that the stream ecosystem is being stressed. These stresses include sediment accumulation, low dissolved-oxygen concentration, increased stream temperatures, and dense macrophyte growth.

Streamflows during WY 1985 and 1986 were 44 and 60 percent greater than the mean (WY 1955-86), respectively. The highest annual mean discharge recorded at Black Earth Creek at Black Earth since monitoring began in 1954 was $53.4 \mathrm{ft}^{3} / \mathrm{s}$, which occurred during WY 1986. Although there have been considerable fluctuations in the annual mean discharge, a general increase since WY 1965 is apparent. Trout populations have increased during the same period. Trout populations, which were near their low of about 110 trout per stream mile in 1958 when the annual mean streamflow was $20.6 \mathrm{ft}^{3} / \mathrm{s}$, have increased to a population of about 1,150 trout per stream mile in 1985 when the annual mean streamflow was $48.1 \mathrm{ft}^{3} / \mathrm{s}$. A regression analysis of the 3 -year moving annual mean discharge and trout population indicates a positive relation with a correlation coefficient of 0.75 .

The increasing streamflow results from above-average precipitation and increased base flow caused by high groundwater levels. Annual mean ground-water levels generally have been rising since WY 1968; the highest ground-water level was recorded in WY 1986. The rising ground-water levels are from ground-water recharge as a result of increases in the cumulative departure from normal precipitation. Precipitation was greater than the long-term (1951-80) annual mean (30.8 in.) by $10.8 \mathrm{in}$. during WY 1985, and by 6.5 in. during WY 1986.

The largest surface-runoff event during the 2-year study occurred on July 25, 1985 and was caused by 5.54 in. of precipitation in 2 days. Based on discharge records (WY 1954-86) at Black Earth Creek at Black Earth, discharge peaks were comparable to about a 5-year flood-recurrence interval.

Black Earth Creek is capable of supporting aquaticmacrophyte biomass comparable to some of the highest values reported in the literature. Biomass was significantly less in 1986 than in 1985, probably because of substrate scouring and removal of plants caused by the flood of July 25, 1985. The densest biomass $\left(789 \mathrm{gdw} / \mathrm{m}^{2}\right)$ in 1985 was found upstream from Cross Plains, and photosynthesis and respiration caused large diurnal fluctuations in dissolved oxygen (5 to $6 \mathrm{mg} / \mathrm{L}$ ). Many of the minimum dissolved-oxygen concentrations recorded at night were less than the State standard for trout. The frequency of occurrence and seasonal succession of macrophyte species in 1985 and 1986 were similar to those in 1981. Potamogeton crispus was dominant early in the year and then senesced in July. $P$. crispus dominated

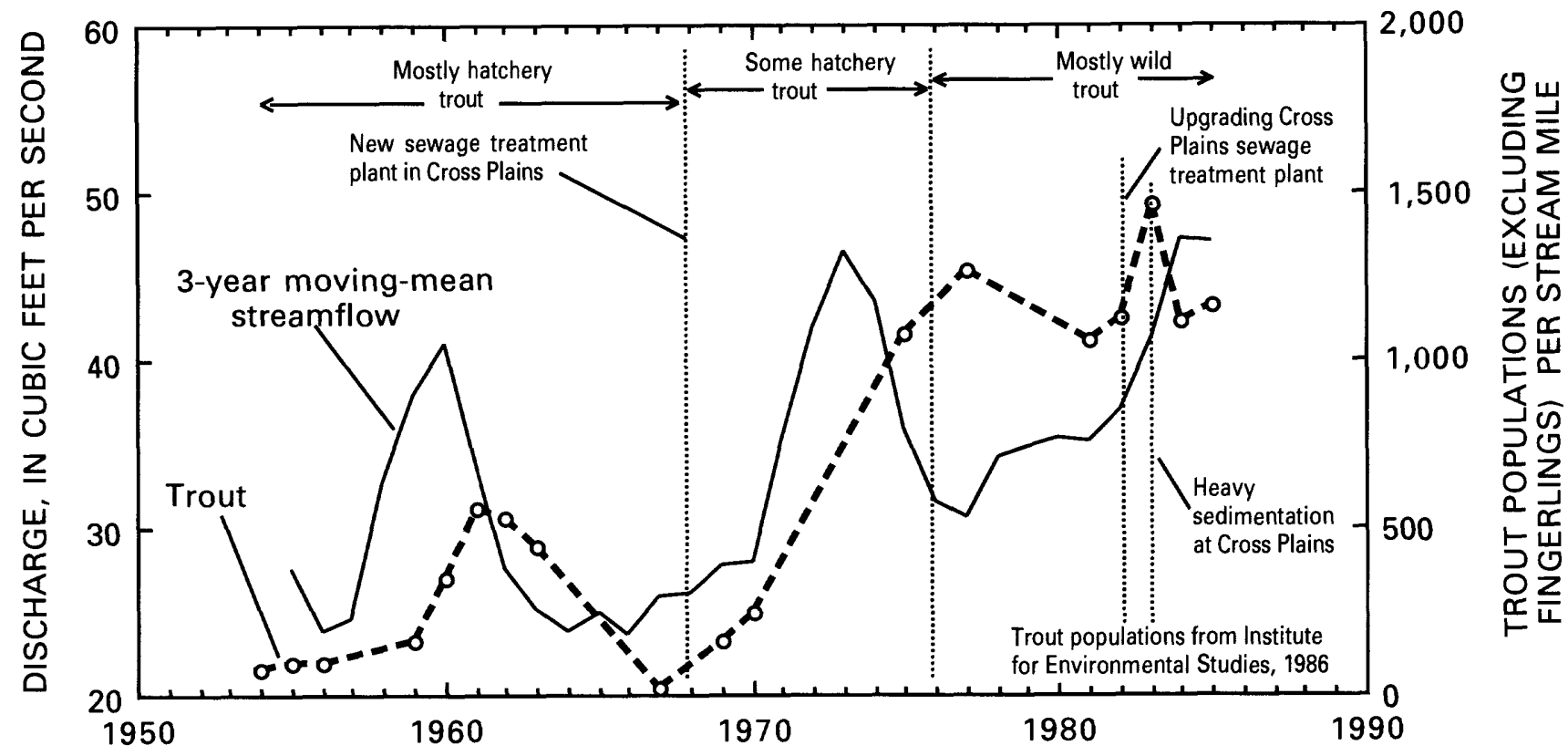

Figure 22. Relation between 3-year moving average streamflow and trout populations for Black Earth Creek, 1955-86. 
upstream because of cool water temperatures, and $P$. pectinatus dominated downstream because of warmer water temperatures. Neither species is native to the area, and both indicate eutrophic conditions.

Discharge from point sources affects Black Earth Creek's water quality. Warm water $\left(4\right.$ to $\left.5 \mathrm{ft}^{3} / \mathrm{s}\right)$ discharged from shallow depths at a gravel-pit pond upstream from Cross Plains caused an increase of 2 to $4{ }^{\circ} \mathrm{C}$ in water temperature and decreased the dissolved oxygen by about $1 \mathrm{mg} / \mathrm{L}$ at a site $1.8 \mathrm{mi}$ downstream. A water-temperature model was used to determine if discharging cooler water from the hypolimnion of the gravel pit would lower the summer water temperatures of Black Earth Creek. Model results indicated that the greatest effect was in the first $1.8 \mathrm{mi}$ downstream from the gravel pit where temperatures could be lowered $2{ }^{\circ} \mathrm{C}$ by augmenting the streamflow with $10^{\circ} \mathrm{C}$ water. The effect would decrease farther downstream, and no change would occur downstream from Black Earth. Surface waters from a landfill in the headwaters of the Black Earth Creek basin, which can drain to Black Earth Creek under certain conditions, contain concentrations of ammonia nitrogen $(60 \mathrm{mg} / \mathrm{L})$, BOD $(420 \mathrm{mg} / \mathrm{L}$, $980 \mathrm{mg} / \mathrm{L})$, and $\operatorname{COD}(1,300 \mathrm{mg} / \mathrm{L})$ that could be detrimental to trout. Effluent discharges from a sewage-treatment plant at Cross Plains contribute annual phosphorus loads to Black Earth Creek comparable to annual loads from nonpoint sources measured at the three upstream gaging stations.

Suspended-sediment, phosphorus, and nitrogen yields varied among the three basins. Garfoot Creek basin had the highest sediment and phosphorus yields during low to moderate runoff. Detention ponds in the Brewery Creek basin became less effective in controlling suspended sediment and phosphorus runoff during periods of high runoff than during moderate runoff and caused this subbasin to have the highest yields during high runoff. The Brewery Creek gaging station had the highest concentrations of suspended sediment and phosphorus during low and high flow periods. The water quality at the Black Earth gaging station is affected by Garfoot Creek and several unnamed tributaries. Phosphorus loads $(4,430 \mathrm{lb} / \mathrm{yr}$ during WY 1985) from the sewage-treatment plant at Cross Plains also increase phosphorus yields at the Black Earth Creek gaging station. Suspended-sediment yields during WY 1985 were 29 percent greater than a 12-year average; yields ranged from 69.5 tons $/ \mathrm{mi}^{2}$ in the Black Earth Creek basin at Cross Plains to 116 tons $/ \mathrm{mi}^{2}$ in the Brewery Creek basin. Phosphorus yields ranged from $312 \mathrm{lb} / \mathrm{mi}^{2}$ in the Black Earth basin at Cross Plains to $628 \mathrm{lb} / \mathrm{mi}^{2}$ in the Brewery Creek basin. Total nitrogen yields ranged from 3,280 $\mathrm{lb} / \mathrm{mi}^{2}$ in the Brewery Creek basin to $6,920 \mathrm{lb} / \mathrm{mi}^{2}$ in the Garfoot Creek basin.

Agricultural runoff, increasing stream temperature, and increased BOD and COD from scouring of the streambed during storms are the likely causes of dissolved-oxygen reduction. These reductions are most noticeable during summer as temperatures warm. The most significant reduction occurred at the Black Earth Creek at Cross Plains gaging sta- tion as a result of the July 25,1985 , flood. Stream discharges increased from 9 to $122 \mathrm{ft}^{3} / \mathrm{s}$ and dissolved-oxygen concentrations decreased to $3.0 \mathrm{mg} / \mathrm{L}$; the dissolved oxygen was less than $4.0 \mathrm{mg} / \mathrm{L}$ for 21 hours, and less than $6.0 \mathrm{mg} / \mathrm{L}$ (the minimum State standard for trout) for 30 hours.

It may be appropriate to continue monitoring streamflow, water temperatures, and dissolved-oxygen concentrations if flow augmentation to Black Earth Creek with bottom water from the gravel-pit pond was implemented at the same stations on Black Earth Creek that were used for this study. After a 2- to 3-year period of cold-water augmentation, aquatic-macrophyte biomass could be determined and species identified, and these data should be compared to the data collected during this study. Because the study period was a high base-flow period, water-quality problems that may be associated with lower flows may not have manifested themselves during this study.

\section{REFERENCES}

Alabaster, J. S., and Lloyd, R., 1982, Water-quality criteria for freshwater fish: Butterworths, $361 \mathrm{p}$.

Audini, R. E., Berkstresser, C. F., Jr., and Knowles, D. B., 1959, Water levels in observation wells in Wisconsin: University of Wisconsin, Wisconsin Geological and Natural History Survey, 192 p.

Barko, J. W., and Smart, R. M., 1981, Sediment-based nutrition of submersed macrophytes: Aquatic Botany, v. 10, p 339-352.

Bergen, W., Best, R., Carper, W. S., Chen, C. F., Dungan, J., Rathrop, R., Lee, K. S., Musselman, C., and Bentura, S., 1985, Analysis of thematic mapper data in resource management case study: Dane County, Wis., Environmental Monitoring Practicum, University of Wisconsin.

Bouchard, R., and Madsen, J. D., 1987, The aquatic macrophyte community of Black Earth Creek, Wisconsin, in Transactions of the Wisconsin Academy of Science, Arts, and Letters: p. 41-55.

Brynildson, O. M., and Mason, J. W., 1975, Influence of organic pollution on the density and production of trout in a Wisconsin stream: Wisconsin Department of Natural Resources Technical Bulletin 81, 16 p.

Brynildson, O. M., and Brynildson, C. L., 1984, Impacts of a floodwater-retarding structure on year class strength and production by wild brown trout in a Wisconsin coulee stream: Wisconsin Department of Natural Resources Technical Bulletin 146, $20 \mathrm{p}$.

Carignan, R., and Kalff, J., 1979, Quantification of the sediment phosphorus available to aquatic macrophytes, in Canadian Journal of Fisheries and Aquatic Sciences: v. 36 , p. $1,002-1,005$.

Chow, V. T., 1964, Handbook of applied hydrology: McGraw-Hill, chapter 7, 34 p. 
Cline, D. V., 1963, Hydrology of Upper Black Earth Creek basin, Wisconsin: U.S. Geological Survey Water-Supply Paper 1669-C.

1965, Geology and ground-water resources of Dane County, Wisconsin: U.S. Geological Survey WaterSupply Paper 1779-U.

Collier, C. R., 1963, Sediment characteristics of small streams in southern Wisconsin, 1954-59: U.S. Geological Survey Water-Supply Paper 1669-B, 34 p.

Downing, K. M., and Merkens, J. C., 1955, The influence of dissolved oxygen concentrations on the toxicity of unionized ammonia to rainbow trout (Salmo gairdnerii Richardson), in Annual of Applied Biology: 43(2), p. 243-246.

Dunst, R. C., 1970, The effect of streamflow upon brown trout reproduction in Black Earth Creek, Wisconsin: M.S. thesis, Madison, University of Wisconsin, 34 p.

Engel, S., 1985, Aquatic community interactions of submerged macrophytes: Wisconsin Department of Natural Resources Technical Bulletin 156, 79 p.

Fassett, N. C., 1957, A manual of aquatic plants: Madison, University of Wisconsin Press, 405 p.

Field, S. J., 1986, Relationship of nonpoint-source discharges, streamflow, and water quality in the Galena River basin, Wisconsin: U.S. Geological Survey Water-Resources Investigations Report 85-4214, 48 p.

Gebert, W. A., 1971, Low-flow frequency of Wisconsin streams: U.S. Geological Survey, Hydrologic Investigations Atlas HA-390, 1 sheet, scale 1:750,000.

Gleason, H. A. and Cronquist, A., 1963, Manual of vascular plants of Northeastern United States and adjacent Canada: D. Van Nostrand, New York, 810 p.

Glocker, C. L., and Patzer, R. A., 1978, Soil survey of Dane County, Wisconsin: United States Department of Agriculture Soil Conservation Service, 193 p.

Hem, J. D., 1985, Study and interpretation of the chemical characteristics of natural water: U.S. Geological Survey Water-Supply Paper 2254, 263 p.

Hendrickson, G. E., and Doonan, C. J., 1972, Hydrology and recreation on the coldwater rivers of Michigan's southern peninsula: U.S. Geological Survey Water Information Series Report 3, $83 \mathrm{p}$.

Holmstrom, B. K., Kammerer, P. A., Jr., and Erickson, R. M., 1986, Water resources data for Wisconsin, 1985: U.S. Geological Survey Water-Data Report WI-85-1, 414 p. 1987, Water resources data for Wisconsin, 1986: U.S. Geological Survey Water-Data Report WI-86, 402 p.

Hunt, R. L., 1979, Removal of woody streambank vegetation to improve trout habitat: Wisconsin Department of Natural Resources Technical Bulletin No. 115, 36 p.

Institute for Environmental Studies, 1986, Black Earth Creek: A watershed study with management options: Water Resources Management Workshop, University of Wisconsin-Madison, Institute for Environmental Studies Report 129, $289 \mathrm{p}$.
LeRoux, E. F., 1963, Geology and ground-water resources of Rock County, Wisconsin: U.S. Geological Survey Water-Supply Paper 1619-X, $50 \mathrm{p}$.

Linsley, R. K., Jr., Kohler, M. A., Paulhus, J. L. H., 1975, Hydrology for engineers (2d ed.): McGraw-Hill Book Company, New York, New York, 482 p.

Madsen, J. D., 1982, The aquatic macrophyte communities of two trout streams in Wisconsin: Madison, University of Wisconsin, M.S. thesis, $108 \mathrm{p}$.

1986, The production and physiological ecology of the submerged aquatic macrophyte community in Badfish Creek, Wisconsin: Ph.D. dissertation, Madison, University of Wisconsin, $449 \mathrm{p}$.

Madsen, J. D. and Adams, M. S., 1985, The aquatic macrophyte communities of two streams in Wisconsin, in Transactions of the Wisconsin Academy of Science, Arts, and Letters: v. 73, p. 198-216.

Michigan State University, 1985, Some aquatic impacts of sediment nutrients and pesticides in agricultural runoff: Liminological Research Laboratory Publication No. 201, $70 \mathrm{p}$.

Mudrey, M. G., Jr., Brown, B. A., and Greenberg, J. K., 1982, Bedrock geologic map of Wisconsin: Wisconsin Geological and Natural History Survey map, 1 sheet, scale $1: 1,000,000$.

Novitzki, R. P., 1973, Improvement of trout streams in Wisconsin by augmenting low flow with ground water: U.S. Geological Survey Water-Supply Paper 2017, 44 p.

Porterfield, George, 1972, Computation of fluvial-sediment discharge: U.S. Geological Survey Techniques of Water Resources Investigations, book 3, chap. C3, 66 p.

Sahai, R., and Sinha, A. B., 1976, Productivity of submerged macrophytes in polluted and non-polluted regions of the eutrophic lake, Ramgarh (M. P.), in Varshney, C. K., and Rzosha, J. (eds.), Aquatic weeds in South East Asia: Proceedings of a regional seminar on noxious aquatic vegetation, New Delhi, India, December 12-17, 1973, Dr. W. Junk, The Hague, 396 p.

Sastroutomo, S. S., 1981, Turion formation, dormancy, and germination of curly pondweed, Potamogeton crispus: Aquatic Botany, 10(2):161-174.

Seely, Ron, 1983, Trout stream get its fill of silt: Madison, Wisconsin, Wisconsin State Journal, March 10, 1983.

University of Wisconsin-Extension, 1988, Erosion and runoff threaten Black Earth Creek: Black Earth Creek Watershed Newsletter, $4 \mathrm{p}$.

U.S. Department of Commerce, 1984, Climatological data, Wisconsin: U.S. Department of Commerce, v. 89, no. $13,27 \mathrm{p}$. 1985, Climatological data, Wisconsin: U.S. Department of Commerce, v. 90, no. 13, 27 p.

1986, Climatological data, Wisconsin: U.S. Department of Commerce, v. 91, no. 13, 27 p. 
Vanlier, K. E., 1963, Ground-water resources of the Alma area, Michigan: U.S. Geological Survey Water-Supply Paper 1619-E, $66 \mathrm{p}$.

Voss, E. G., 1972, Michigan flora, part I: Gymnosperms and monocots: Cranbrook Institute for Science, Bloomfield Hills, Mich., 488 p.

White, R. J., 1972, Trout population responses to habitat change in Big Roche-a-Cri Creek, Wisconsin: Madison, University of Wisconsin, published Ph.D. dissertation, $296 \mathrm{p}$.

White, R. J., and Brynildson, 1967, Guidelines for management of trout stream habitat in Wisconsin: Wisconsin Department of Natural Resources Technical Bulletin no. $39,64 \mathrm{p}$.

Wischmeier, W. H., and Smith, D. D., 1978, Predicting rainfall-erosion losses; a guide to conservation planning: U.S. Department of Agriculture Handbook, no. 537.
Wisconsin Department of Natural Resources, 1980, Wisconsin trout streams: Wisconsin Department of Natural Resources, $67 \mathrm{p}$.

Wisconsin Department of Natural Resources, 1982, Draft fisheries area master plan: Wisconsin Department of Natural Resources.

1986, Nonpoint source pollution: where to go with the flow, Wisconsin's challenge for the next decade: Wisconsin Department of Natural Resources, JanuaryFebruary, $39 \mathrm{p}$.

Wong, S. L., Clark, B., Kirby, M., and Kosciuw, R. F., 1978, Water temperature fluctuations and seasonal periodicity of Cladophora and Potamogeton in shallow rivers: Journal of the Fisheries Research Board of Canada, v. 35, p. $866-870$. 